\title{
O Direito nas lutas urbanas uma análise do uso do Direito pelos movimentos sociais desde 1988
}

\author{
Amanda Paulista de Souza
}

Dissertação apresentada à Faculdade de Arquitetura e Urbanismo da Universidade de São

Paulo para obtenção do título de Mestre Área de concentração: Habitat

Orientadora: Prof ${ }^{a}$. Dra. Maria Lucia Refinetti Rodrigues Martins 
Autorizo a reprodução e divulgação total ou parcial deste trabalho, por qualquer meio convencional ou eletrônico, para fins de estudo e pesquisa, desde que citada a fonte.

EXEMPLAR REVISADO E ALTERADO EM RELAÇÃO À VERSÃO ORIGINAL, SOB RESPONSABILIDADE DA AUTORA E ANUÊNCIA DA ORIENTADORA. O ORIGINAL SE ENCONTRA DISPONÍVEL NA SEDE DO PROGRAMA DA FAU-SP (Dezembro 2017).

E-mail da autora: apaulista.souza@gmail.com

Imagem da capa: autoria desconhecida; Fonte: página do MTST Brasil no facebook.

Ver em: $<$ https://goo.gl/7riGuc $>$. Acesso 20 de julho de 2017.

Capa: Flávia T. Peretto Design Gráfico: He Nem Kim Revisão: Rosana Yamaguti e Otavio Constantino

\section{FICHA CATALOGRÁFICA}

Catalogação na Publicação

Serviço Técnico de Biblioteca

Faculdade de Arquitetura e Urbanismo da Universidade de São Paulo

5719

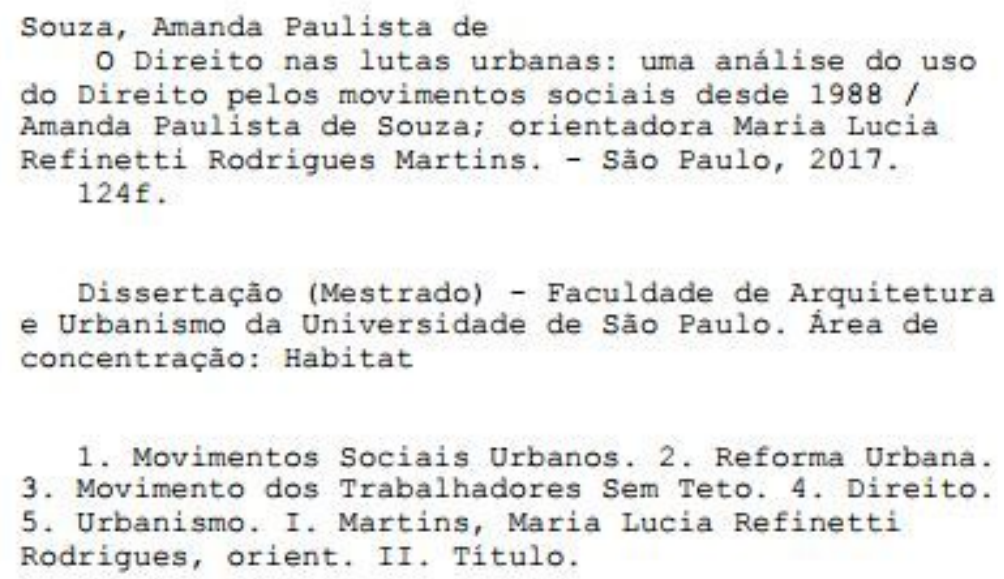




\section{agradecimentos}

Nos momentos extenuantes que vivi durante a experiência do Mestrado, me vinha sempre à mente um estranho não-lugar no qual eu parecia estar: a alguns advogados e militantes, pareço ser muito arquiteta; a outros arquitetos, muito advogada; a alguns colegas e referências da academia, talvez muito militante. Ao término desta dissertação, continuo sem saber muito bem onde me coloco; mas de uma coisa eu tenho certeza: carrego o urbanismo, o direito e a militância comigo e, em um verdadeiro esforço de equilíbrio, escrevo esta dissertação.

A maioria das pessoas que aqui agradeço foram (e são) fundamentais, de maneira consciente ou inconsciente, nesta busca pelo equilíbrio.

Agradeço à minha orientadora, Malu, por ter me acolhido nestes últimos 2 anos e meio. Obrigada pelas dúvidas, pelos puxões de orelha, pelo incentivo e, sobretudo, pela compreensão e sensibilidade nos momentos difíceis, do mestrado e da vida. Obrigada também por me mostrar que os caminhos da academia são tortuosos, mas que com bom-humor e confiança, as coisas deslancham.

Gostaria de agradecer também ao Pedro Arantes e Karina Leitão, que fizeram parte da minha banca de qualificação. Sem a sabedoria de vocês, esta dissertação estaria empacada Deus sabe lá onde. Obrigada pelos caminhos, pela disponibilidade e por acreditarem no potencial desta dissertação. Especialmente ao Pedro, agradeço pelas conversas e pela preocupação carinhosa. 
Ao professor Paulo Cesar Xavier Pereira que, com uma dose de divertimento e provocação, me incentivou durante todo o processo do Mestrado. Obrigada pelas sugestões de bibliografia e de seminários, pelo olhar atencioso.

Ao professor Luis Fernando Massonetto, que nestes últimos tempos têm sido minha referência no Largo São Francisco e que têm me mostrado que o urbanismo pode ter eco naquelas paredes. Aos colegas do SAJU, que me ajudaram a ser quem eu sou hoje e aos mais novos, que sempre dão um jeito de me fazerem sentir em casa quando volto às Arcadas.

Aos amigos do coração, que me ajudaram a tirar a cabeça da dissertação, quando isso foi possível, e pela compreensão pelas ausências. Aos amigos de mestrado com os quais, apesar da pouca convivência, pude aprender e me divertir muito. Aos colegas de SMDU e SMUL, que acompanharam muitos dos 'causos' dessa dissertação.

Não poderia deixar de destacar o quão tem sido transformadora a vivência que, motivada por esta dissertação, estou tendo no MTST... cada companheiro com quem pude conversar, cada ocupação que eu pude conhecer e cada debate que eu pude participar tem sido um aprendizado valioso; agradeço especialmente os colegas da Brigada Jurídica, com os quais pude compartilhar muitas reflexões, algumas expostas neste trabalho.

Obrigada aos lutadores com os quais pude conviver em outros momentos e movimentos e que foram fundamentais para as reflexões contidas nesta dissertação; agradeço especialmente os companheiros Dito e a Maria dos Anjos, por quem guardo grande admiração, pelo exemplo e pela história.

À minha família, que aturou minhas ausências, cansaços e as longas conversas sobre esta dissertação.

Aos meus pais, meus guardiões, eu não conseguiria agradecer o bastante. Obrigada por terem me incentivado de todas as formas possíveis, por terem me ajudado tanto e por sempre olharem por mim.

Às minhas queridas companheiras de trabalho e de coração: He Nem Kim, Rosana Yamaguti e Flávia Peretto, que acompanharam todo este processo, se dispondo a ler cada linha desta dissertação, lidando com muitas das minhas crises e me incentivando literalmente dia após dia. Este trabalho deve muito a vocês, que estiveram ao meu lado 
nos momentos mais tortuosos... a melhor maneira de agradecê-las é fazer a mesma coisa por vocês, com todo o carinho e eficiência. Muito obrigada!!

Ao Otávio, meu companheiro. Obrigada por ter dado tudo de si e de, com carinho e responsabilidade, ter se disposto a vivenciar este processo... e apesar de ter escrito páginas e mais páginas nos últimos meses, subitamente me fogem as palavras que poderiam traduzir o quanto eu agradeço por ter tido você ao meu lado durante este processo. 
agradecimentos 3

sumário $\quad 6$

$\begin{array}{ll}\text { resumo } & 7\end{array}$

$\begin{array}{lc}\text { abstract } & 8\end{array}$

introdução 9

Apresentação 9

Apontamentos Metodológicos 13

capítulo 1. o Direito na Reforma Urbana 21

Viver o pleno direito: o processo constituinte da década de $1980 \quad 22$

A Reforma Urbana nos marcos da cidadania

Dos direitos ao Direito ou os rumos do campo jurídico-institucional 40

capítulo 2. $2013 \mathrm{e}$ as novas emergências políticas 53

As rupturas das Jornadas de Junho de 2013

capítulo 3. o MTST e os usos do direito 60

Breve histórico do MTST 61

Do campo ao urbano, do urbano à autonomia (1997-2003) 61

A construção de um movimento autônomo (2003-2009) 65

Um novo campo político, uma nova inserção (2009 em diante) 66

Concepções políticas do MTST $\quad 71$

Ação direta e distanciamento institucional $\quad 72$

Ocupações como estratégia de organização da classe trabalhadora $\quad 74$

MTST e a Reforma Urbana $\quad 80$

Um novo olhar para o Direito no MTST 83

capítulo 4. os caminhos da Reforma Urbana: conclusões e apontamentos 96

$\begin{array}{ll}\text { considerações finais } & 107\end{array}$

$\begin{array}{ll}\text { bibliografia } & 110\end{array}$ 
Neste trabalho, desenvolveremos uma análise dos principais usos do direito prioritariamente levados a cabo nas lutas urbanas, notadamente pela bandeira de luta da Reforma Urbana - um período que, conforme veremos, se estende desde os anos finais da década de 1980 até os dias atuais. Para tanto, concentraremos nossa pesquisa em dois momentos: no primeiro, daremos destaque ao principal uso do direito e seu peso estratégico veiculado pelo Movimento Nacional de Reforma Urbana (MNRU) no período que abrange desde o final da década de 80 até 2013, quando há uma ruptura com as formas de lutas institucionalizadas e abre-se um novo período de lutas urbanas; a partir daí, focaremos nossa análise nos principais usos do direito evocados pelo Movimento dos Trabalhadores Sem Teto (MTST) e apontaremos como que o peso e a centralidade do direito enquanto estratégia nas lutas urbanas coincide com ciclos de lutas, cuja conjuntura política é específica e única e nos quais diferentes movimentos, leituras de realidade e projetos políticos são protagonistas.

Palavras-chave: Movimentos Sociais Urbanos, Direito, Urbanismo, Reforma Urbana, Movimento dos Trabalhadores Sem Teto (MTST). 


\section{abstract}

This master's thesis will develop an analysis of the main uses of the Law in urban struggles, notably the struggle banner of Urban Reform - a period that, as we shall see, extends from the late 1980s to the present day. To do so, we will focus our research in two moments: first, we will highlight the main usage of the Law and its strategic weight by the National Movement for Urban Reform (MNRU) in the period from the end of the $1980 \mathrm{~s}$ until 2013, when there is a rupture with the institutionalized forms of struggles and emerge a new period of urban struggles; then we will focus our analysis on the main uses of the Law evoked by the Movement of Homeless Workers (MTST) and we will point out how the weight and centrality of the Law, as a strategy in urban struggles, coincides with the cycles of the urban struggles, whose political conjuncture is specific and unique, in which different movements, readings of reality and political projects are protagonists.

Keywords: Urban Social Movements, Law, Urbanism, Urban Reform, Movement of Homeless Workers (MTST). 


\section{introdução}

\section{Apresentação}

Foi na Vila Itororó, atualmente um conhecido espaço cultural do circuito urbano alternativo da cidade de São Paulo, onde tive o meu primeiro contato com a militância política, com a luta pela moradia e com as crises do uso do Direito. Durante os anos de 2009 a 2012, uma boa parte do meu esforço voltou-se à Vila, fosse em reuniões na comunidade, em exaustivos debates no SAJU ${ }^{1}$ - coletivo de extensão da Faculdade de Direito da USP que acompanhava a Vila e do qual eu fazia parte -, em horas trabalhadas em peças judiciais cujo conteúdo era completamente novo para mim, etc. A verdade é que eu me formei advogada e militante mais na Vila Itororó do que nos bancos do Largo São Francisco. Na Vila - ou a partir dela, no SAJU -, pude mergulhar nas discussões sobre os limites do direito, sobre seu papel enquanto estratégia de luta na comunidade e sobre alguns caminhos à necessária tarefa de desmistificá-lo, já que era recorrente entre os

\footnotetext{
${ }^{1}$ O SAJU-SP (Serviço de Assessoria Jurídica Universitária da Universidade de São Paulo) é um grupo de extensão ligado à Faculdade de Direito da USP e fundado em 2006. Apesar de estar oficialmente ligado à Universidade, o SAJU é, na prática, um grupo com grande autonomia, cujas atividades são geridas, planejadas e avaliadas pelos seus participantes. Ao longo da sua história, o SAJU já atuou com diferentes demandas - alfabetização de adultos, trabalhadores terceirizados da própria faculdade, cooperativas de trabalhadores, pessoas encarceradas, etc - mas, curiosamente, a questão urbana se manteve como tema perene, de maneira que foi possível ao grupo desenvolver uma forte relação com os movimentos sociais de moradia, especialmente do centro da cidade. Durante parte do período que eu participei do SAJU, notadamente entre 2009 a 2012, concentramos nossas energias na Vila Itororó - cujos moradores foram removidos e realocados em 2011 e 2012 - seja no âmbito judicial, a partir da atuação nos processos de Desapropriação e Usucapião, seja no âmbito político. Já a partir de 2012, com a realocação das famílias da Vila, os trabalhos se concentraram em atividades formativas com a juventude da ocupação Mauá, no centro de São Paulo.
} 
moradores a aposta no direito como o principal instrumento para a conquista da sua moradia e consequente realização de justiça social.

De fato, quando eu comecei a acompanhar a Vila Itororó, as pautas das reuniões se restringiam basicamente aos informes sobre o andamento de duas ações judiciais: a ação de Desapropriação ${ }^{2}$ da comunidade, proposta pelo Governo do Estado em face da Fundação Leonor de Barros Camargo (proprietária dos imóveis em discussão) e a ação de Usucapião ${ }^{3}$, proposta pelos moradores da Vila Itororó para que fosse reconhecido seu direito de propriedade sobre os imóveis que habitavam e que, em uma confusão entre direito à propriedade e direito à moradia, ilustrava a grande aposta dos moradores no direito como realizador dos seus interesses e demandas.

Enquanto a Desapropriação andava de vento em popa, dado a matéria e os interesses nela conjugados, a Usucapião, uma ação cujos procedimentos são exigentes e detalhistas, andava a passos lentíssimos. Apesar do engajamento dos moradores, advogados e do SAJU para superar toda a dificuldade inicial de reunir documentos, de fazer um levantamento dos moradores, de redigir as peças processuais, etc., após o ajuizamento da ação, a responsabilidade pelo ritmo do seu andamento passou a ser inteiramente do juízo - e assim, passados quase 10 anos de ação, esta encontra-se ainda nos seus estágios mais iniciais, longe de ser julgada.

Contudo, mesmo com todos os problemas e limitações, as ações judiciais e especialmente a Usucapião eram a pauta central de organização e mobilização da comunidade. Nós do SAJU, estimulados pela demanda recorrente dos moradores, pensávamos estratégias mirabolantes para o andamento e sucesso nos processos: desde aventar a possibilidade de encomendarmos pareceres técnicos de acadêmicos que mostrassem a importância cultural e social da Vila Itororó e de seus moradores, até garantir os procedimentos para eventualmente conseguir levar o caso para a Corte Interamericana de Direitos Humanos.

Porém, a verdade é que, à medida que o tempo foi passando, o direito dos moradores que, em teoria, só precisava ser reconhecido judicialmente, parecia cada vez mais longínquo. Era com tristeza que víamos decisões e mais decisões afrontando

\footnotetext{
${ }^{2}$ Autos n· 0134155-34.2007.8.26.0053, da 1 a Vara da Fazenda Pública de São Paulo/SP

${ }^{3}$ Autos n. 0136490-45.2008.8.26.0100, da 2 a Vara de Registros Públicos da Capital - São Paulo/SP
} 
abertamente a letra do Estatuto da Cidade; era com resignação que confirmávamos o abismo entre as duas ações judiciais; era com falsas esperanças que fazíamos novos recursos e que informávamos o andamento dos processos para a comunidade. Os moradores, no entanto, falavam sobre os seus direitos, sobre a Constituição Federal e continuavam a apostar na saída pelo direito ou mesmo no acolhimento de suas demandas por parte de algum vereador... sua convicção no direito e nos seus direitos enquanto cidadãos parecia muni-los de uma certa confiança na inevitabilidade do triunfo da justiça.

Após anos de construção de uma identidade coletiva política dos moradores, da constatação de demora exacerbada da ação de Usucapião e do cenário de iminência do cumprimento da imissão na posse decretada na ação de Desapropriação, as manifestações políticas dos moradores se tornaram mais recorrentes e intensas; começou a ser desenhada uma solução de saída negociada - ainda que polêmica -, que resultou na realocação dos moradores em novos prédios da CDHU em áreas a poucos quilômetros (quando não, metros) da Vila Itororó. Grande parte dos moradores aceitou tal proposta de imediato, especialmente por conta das condições de precariedade que enfrentavam diariamente em suas casas na comunidade; no entanto, diante da proposta sobreveio também uma crítica ferrenha que acreditava que aceitar os termos do poder público seria o mesmo que 'jogar a toalha' pois, diante dos direitos e garantias que os moradores tinham em suas mãos, era possível exigir melhores termos. Era como se os direitos, por estarem positivados em leis e mesmo na Constituição Federal, garantissem por si só aos moradores uma moeda de troca poderosa, mas que, na verdade, se esvaía rapidamente diante de obstáculos políticos, econômicos e jurídicos colocados pelo Estado representado por seus mais diferentes entes e âmbitos - o Poder Judiciário, o Poder Executivo Municipal, o Poder Executivo Estadual, entre outros. Falar em "direito constitucional à moradia" e "ter direito à Usucapião" era quase que um discurso vazio nas mesas de negociações com tais entes. Neste embate, então, me deparei pela primeira vez com o abismo que separa os direitos como discurso e a sua realização - e, especialmente o que tal abismo pode implicar em termos de lutas populares.

Durante todo este processo, foi recorrente no SAJU o questionamento sobre se a insistente crença dos moradores no Direito e nos seus direitos era reflexo da nossa atuação e mesmo da nossa postura enquanto estudantes de Direito. Porém, à medida em que fui transitando por outros espaços de lutas urbanas, fui percebendo como o Direito 
era levantado pelos movimentos de moradia e comunidades e reforçado por técnicos e serviços legais (realizados por ONGs ou por entidades populares) como uma estratégia chave nas lutas, inclusive naquelas voltadas à Reforma Urbana. Apesar das sistemáticas violações dos direitos da classe trabalhadora no âmbito da moradia, do trabalho, da mobilidade urbana, da segurança pública, etc., a ideia de que "somos cidadãos", "temos nossos direitos" e de que "o Poder Público tinha que cumprir suas obrigações" era muito recorrente.

Entretanto, já na segunda metade dos anos 2000, a aposta no Direito, traduzido pela priorização das disputas no campo jurídico-institucional, começou a ser fortemente criticada, assim como os movimentos sociais que lhe embasavam. No programa de Pós-graduação da FAU-USP, no qual desenvolvi a presente dissertação, ao mesmo tempo que pude compreender melhor o debate acadêmico e urbanístico sobre as lutas pela Reforma Urbana até então travadas, fui instigada a pensar com mais profundidade sobre o papel que o Direito desempenhava em tais lutas.

Foi então que eu pude aprofundar meus conhecimentos nos escritos de uma literatura especializada que, há tempos, vinha apontando as limitações das apostas jurídicas e institucionais durante a Reforma Urbana e os processos que o mercado estava liderando nas cidades brasileiras, além das perspectivas, potencialidades e incertezas abertas pelas então recém travadas Jornadas de Junho de 2013. Às leituras, no entanto, sobrevinham diversas perguntas: como abordar essa aposta no Direito e na luta institucionalizada, tão característica da Reforma Urbana, de maneira contextualizada? Quais os caminhos para abordar a questão de forma a localizá-la no cenário político e social a partir do qual ela fora firmada? E, principalmente, como pensar a Reforma Urbana como bandeira de luta diante de um novo cenário que se abria, especialmente a partir das rupturas evocadas pelas manifestações de 2013? Ela continuava a ser uma pauta reivindicada no cenário das lutas urbanas inaugurado em 2013 e, se sim, por quais atores? Estaríamos rumando, de fato, para um novo momento das lutas urbanas, em que os ideais do direito e da esfera institucional adquiriram um novo peso e significado, podendo, inclusive, ser um dos elementos de caracterização de um novo período de lutas?

Tais indagações direcionaram nossa pesquisa e foram sintetizadas em uma pergunta, que esta dissertação pretende responder: quais as pistas que o uso do direito pode revelar sobre as lutas pela Reforma Urbana? 


\section{Apontamentos Metodológicos}

Para respondermos à pergunta acima enunciada, optamos por fazer dois recortes metodológicos importantes: um referente ao marco temporal ao qual a pesquisa se refere e outro referente aos movimentos sociais cujos usos do direito serão privilegiados na presente análise.

Sobre o marco temporal, entendemos que ele abrange um período significativo entre a segunda metade dos anos 80 , especialmente após a promulgação da Constituição Federal de 1988, e os dias atuais, visto que as lutas populares pela Reforma Urbana foram inauguradas efetivamente na década de 80 (apesar dela ter sido aventada já em 1963, com as discussões acerca das Reformas de Base do Governo João Goulart) e continuam a ser travadas atualmente por diferentes movimentos sociais.

Com relação ao segundo ponto, optamos por direcionar a análise sobre os usos do direito no período mais recente de lutas ao Movimento dos Trabalhadores Sem Teto (MTST). Tal escolha pareceu necessária no âmbito da metodologia desenvolvida nesta dissertação (sobre a qual falaremos adiante) pois, se dos anos 80 até os anos iniciais da década de 2010 é possível analisar o uso do direito por meio do estudo das práticas dos movimentos sociais aglutinados especialmente em torno do Movimento Nacional pela Reforma Urbana (MNRU) - o principal expoente da luta pela Reforma Urbana -, o período mais recente de lutas, inaugurado especialmente pelas Jornadas de Junho de 2013, demandava a escolha de um movimento específico para ser objeto de estudo e, assim, evitar que caíssemos numa tentativa exaustiva de pesquisa sobre os usos do direito feitos por diferentes movimentos e sujeitos sociais que atualmente reivindicam a Reforma Urbana.

Ao visualizarmos o cenário de lutas após 2013, vemos o reposicionamento e a conformação de organizações e forças sociais que compõem as lutas urbanas, dentre as quais três parecem se destacar. A primeira delas é representado pelos movimentos sociais historicamente ligados à Reforma Urbana, especialmente o MNRU e os movimentos de moradia tradicionais como a União dos Movimentos de Moradia (UMM), a Central de Movimentos Populares (CMP), o Movimento Nacional de Luta pela Moradia (MNLM) e 
Confederação Nacional das Associação de Moradores (CONAM). Tais movimentos, apesar continuarem a ter um papel de destaque na conjuntura e nas lutas urbanas, parecem ter perdido sua capacidade ofensiva e estar em um processo de recuperação e reavaliação de suas leituras de realidade e práticas de luta.

A segunda é representado pelas 'novas' formas de resistências ou os 'novíssimos movimentos sociais', como os denomina Erminia Maricato em alusão à obra de Eder Sader. Tais movimentos, caracterizados especialmente pela autonomia e pela organização em rede, se destacaram a partir das ações do Movimento Passe Livre (MPL) - um movimento horizontal, politizado, apartidário e crítico à política institucional que conseguiu mobilizar milhares de pessoas nas ruas -, que, apesar de ter sido fundamental na condução das Jornadas de Junho de 2013, parece não protagonizar mais o debate público sobre a Reforma Urbana. Dando sequência, dentre essas novas formas de resistência, podemos citar, no Município de São Paulo, as lutas contra a concessão dos terrenos localizados embaixo do viaduto Júlio de Mesquita Filho, contra a construção de torres no terreno ao lado do Teatro Oficina e a favor da implementação do Parque Augusta 4. Contudo, ainda que tais formas de resistência possam se desdobrar em importantes processos de reivindicação do direito à cidade, o caráter pontual e isolado de suas práticas faz com que tais iniciativas tenham parcas condições de massificação de lutas e aglutinação de apoiadores, de maneira a restringir muito o espectro da resistência. Assim, tais iniciativas pontuais parecem ter pouca capacidade de massificação social e de se inserir no cenário político da cidade de maneira a influenciar na correlação de forças.

Já o MTST, a terceira força social ora destacada, parece ser um ator que reivindica explicitamente a bandeira de luta da Reforma Urbana a partir de um projeto político e popular (sobre o qual nos deteremos no capítulo 03 desta dissertação) e que tem grande notoriedade no cenário político atual e potencialidade de influência política em razão da sua capacidade de organização e mobilização das camadas populares. Foi isso o que nos gerou o interesse de análise e é o que justificativa a sua escolha como referencial de observação.

\footnotetext{
${ }^{4}$ De acordo com a apresentação de Raquel Rolnik no XVII ENANPUR.
} 
Destacados os dois recortes metodológicos fundamentais desta pesquisa, passemos à apresentação dos instrumentos de pesquisa utilizados. De maneira geral, nos utilizamos dos seguintes instrumentos:

(i) levantamento e análise bibliográfico;

(ii) levantamento de produção legislativa no âmbito federal;

(iii) pesquisa e levantamento de fotos e notícias de jornais de grande circulação nacional ou da mídia alternativa, publicadas também em redes sociais;

(iv) levantamento e análise documental relativa ao MTST; e

(v) observação participante nos espaços do MTST.

Vejamos, a seguir, como tais fontes foram mobilizadas em cada um dos capítulos presentes nesta dissertação:

No Capítulo 01, nos propusemos a fazer um resgate histórico das lutas pela Reforma Urbana travadas no período que compreende os anos finais da década de 80 até os anos iniciais da década de 2010, sempre com o esforço de situá-las ao contexto político vigente, de modo a permitir a compreensão da centralidade do uso do direito e da priorização das intervenções no âmbito jurídico institucional nas estratégias adotadas pelos atores envolvidos com essa agenda.

Apesar de ser um longo período, entendemos que ele tem uma coerência no que tange ao uso do direito, pois este era diretamente associado com um ideal de cidadania e de centralização das práticas dos movimentos sociais no campo jurídico-institucional. Considerou-se, neste sentido, o peso que o direito adquiriu nesse período, ainda que sua instrumentalização - primeiramente a partir do ideal de direitos e depois da legislação tenha sido redirecionada.

Retomaremos, neste sentido, o contexto político e social do período, para indicar como que, dos processos mais amplos vivenciados na esfera política brasileira, a luta pela Reforma Urbana foi formulada de maneira a priorizar o campo jurídico-institucional e centrar suas ações no Estado, em busca da realização dos direitos de cidadania.

Para tanto, nos utilizamos da seguinte metodologia:

(i) priorização do levantamento e análise bibliográficos, por entender que o período retratado já fora objeto de diversas pesquisas, balanços e avaliações, elaborados inclusive por pessoas que participaram ativamente desse processo. Como, no período, o direito era encarado como uma estratégia prioritária de 
lutas do MNRU e demais movimento atuantes, diversas análises que não necessariamente realizadas no âmbito do Direito apontam para tal priorização e discutem os efeitos dela nos rumos da luta pela Reforma Urbana no período. Neste sentido, entendemos que tais fontes de pesquisa foram absolutamente relevantes e capazes de subsidiar a análise por nós pretendida, ainda que muitos dos autores selecionados transitem por diferentes áreas do conhecimento que não o Direito, como é o caso das Ciências Sociais e do Urbanismo.

Nesse sentido, foram selecionados textos de autores como: Ermínia Maricato, Carlos Michiles, Pedro Fiori Arantes, Ana Amélia Silva, Nelson Saule Junior, Raquel Rolnik, Orlando dos Santos Junior, Eder Sader, Lúcio Kowarick, Nabil Bonduki, Luciana Tatagiba e Edésio Fernandes.

(ii) subsidiariamente às pesquisas bibliográficas, como forma de destacar os marcos legislativos e institucionais relativos à regulamentação da política urbana nacional aprovados ao longo do período retratado no capítulo, foi feito um levantamento das legislações urbanísticas aprovadas a nível federal por meio da pesquisa no acervo digital do Senado Federal a partir de palavras-chave "urbano" e variações, "moradia", "fundiário" e variações, "cidade" e variações, além de um levantamento dos principais espaços institucionais voltados à discussão da política urbana no âmbito federal, feito a partir da consulta a documentos disponibilizados no site do Ministério das Cidades e da consulta à bibliografia já citada no tópico anterior.

(iii) foi também realizada uma pesquisa nos sites do Senado Federal e do Acervo Chico Buarque de Holanda, este último administrado pela Fundação Perseu Abramo, para levantar notícias de jornais e fotos referentes ao período analisado, os quais, mais do que meras ilustrações, se mostraram fontes potencialmente reveladoras do destaque social que o Direito emanava à época.

No Capítulo 02, destacaremos brevemente o contexto das Jornadas de Junho de 2013 como um momento reivindicativo de ruptura com as formas de ação, estratégias e mesmo com os movimentos sociais até então protagonistas dos processos de luta pela Reforma Urbana. Destacaremos, ainda, como que, a partir do novo contexto de lutas, 
emergiram movimentos sociais importantes que também reivindicavam tal bandeira e apontavam para a necessidade de transformá-la ao distanciá-la do campo jurídico-institucional e da centralidade da figura do Estado.

Para tanto, nos utilizamos das seguintes ferramentas:

(i) priorização do levantamento e análise bibliográfico, a partir do qual destaca-se a consulta de textos elaborados por Pedro Fiori Arantes, Carlos Vainer, Ermínia Maricato, Paulo Eduardo Arantes e pelo Movimento Passe Livre (MPL). Tais autores e entidades foram escolhidos pois, para além de tantos outros que se propuseram a investigar os sentidos das Jornadas de Junho de 2013 no plano político e filosófico (como Marcos Nobre e Pablo Ortellado), estes voltaram suas análises para os processos de produção do urbano, buscando entender como as cidades estavam relacionadas com essa ruptura na prática política da sociedade e como essa ruptura se voltou para as lutas urbanas.

(ii) levantamento e seleção de fotos e notícias referentes ao período retratado, o qual foi amplamente acompanhado pelos jornais de grande circulação e mídias alternativas. Tal levantamento foi muito rico, inclusive para ajudar na compreensão dos sentidos, enfoques e destaques dados às práticas e às bandeiras de luta do período, ainda mais porque a narrativa sobre esse processo ainda está em disputa.

No Capítulo 3, será apresentado o levantamento que teve por objeto o MTST e os usos do direito por ele mobilizados no período mais recente de lutas pela Reforma Urbana. Entretanto, como forma de introduzir o movimento e possibilitar a análise que será realizada no capítulo seguinte, faremos um breve relato sobre a trajetória histórica de criação e consolidação do MTST desde 1997 até os dias atuais e destacaremos suas concepções políticas que nos pareceram mais importantes para o aprofundamento da análise posterior.

Em razão do parco material acadêmico disponível sobre o MTST e a atualidade da pesquisa pretendida neste capítulo, nos pareceu que as fontes deveriam ser diferentes daquelas privilegiadas até então. Neste sentido, a pesquisa que deu origem ao capítulo foi levantada a partir dos seguintes instrumentos de pesquisa: 
(i) levantamento e análise de documentos produzidos pelo MTST sobre sua forma de organização, linhas políticas, bandeiras de luta, etc., em geral correspondente a Cartilhas, Sistematização de Encontros, Cartas Abertas, Cartas de Repúdio, textos de circulação interna, textos assinados pelo movimento disponibilizados na internet, textos veiculados em redes sociais e livros e textos produzidos por Guilherme Boulos, uma das mais destacadas lideranças do movimento.

(ii) levantamento e análise de produções acadêmicas sobre o movimento, especialmente teses e dissertações. Como mencionado, tal universo foi bastante restrito em números, porém muito qualificado e, por isso, de grande valia para as exposições e análises traçadas ao longo dos capítulos 3 e 4 desta dissertação. Destacamos, dentre tais produções, a da Débora Cristina Goulart, que se debruçou detidamente à análise do MTST e do relato da sua história e sistematização de linhas políticas.

(iii) análise de notícias de jornais oriundas da grande mídia ou da mídia alternativa, em razão da proximidade temporal do objeto pesquisado. Estas fontes foram particularmente importantes no retrato das ações do movimento, pois, em geral, registraram informações como datas, locais, estimativa de participantes em atos, fotos e mesmo vídeos. Cabe aqui ressaltar apenas que tais registros não necessariamente traduzem acertadamente o posicionamento e as motivações do movimento, porém são potencialmente reveladoras dos impactos sociais que suas ações provocaram. (iv) levantamento e análise de vídeos disponibilizados na internet produzidos pelo próprio movimento ou por agentes externos. Aqui, destacam-se desde vídeos feitos espontaneamente até entrevistas e documentários feitos com coordenadores do movimento e os acampados, a partir dos quais foi possível levantar discursos ora mais espontâneos, ora mais formais, e cujo conteúdo dava elementos para entendermos como o discurso relacionado ao direito foi e é mobilizado pelo movimento.

(iv) observação participante em diferentes espaços organizativos - dos quais as ocupações consolidadas e espaços internos do movimento são os mais 
destacados - e de mobilização - como os trancamentos de vias públicas, passeatas, atos, pré e pós-atos, palestras e atividades de formação.

Tal instrumento de pesquisa foi utilizado justamente para viabilizar o contato direto da pesquisadora com o "objeto de estudo", uma vez que, como dito, são poucos os trabalhos acadêmicos sobre o movimento, ainda mais sobre os usos do direito por ele acionados. Nesse sentido, a observação foi empregada para que pudessem ser sistematizados os usos dados ao direito nas ações do movimento em seus diversos âmbitos de atuação (trabalho de base com acampados e com a comunidade do entorno, atos e intervenções em pontos-chave da cidade, e relações com o Poder Público), e, posteriormente, permitir a compreensão do peso e do papel que o direito cumpre no âmbito das lutas e do projeto político da Reforma Urbana.

Ainda quanto a esse ponto, é importante destacar que a entrada no campo se deu por meio da Brigada Jurídica do MTST, um coletivo formado por advogadas e advogados voluntários responsável por acompanhar o movimento em vários tipos de demanda, como: diálogo e mediação com os agentes do Estado em atos e manifestações; acompanhamento e realização de defesa judicial em ações criminais ou de reintegração de posse; participação em mesas de negociação com o Poder Público; realização de mutirões jurídicos para os acampados; realização de formações políticas e jurídicas sobre temas relacionados ao direito (como a Reforma da Previdência e Reforma Trabalhista) para os acampados, entre outros. A oportunidade de acompanhar a Brigada Jurídica do MTST representou um ponto de vista privilegiado para entender o movimento e a relação dele com o direito, afinal, a partir dessa posição, foi possível transitar por diversas instâncias organizativas do movimento, participar de debates e avaliações sobre as práticas jurídicas do movimento e de participar de muitos dos seus processos de mobilização. E, se por um lado, a elaboração do campo a partir da Brigada Jurídica poderia ser um fator que poderia acarretar na supervalorização das práticas jurídicas do movimento, por outro, o esforço constante de conjugação entre as informações colhidas em campo com as demais fontes de pesquisa aqui indicadas para o capítulo foi fundamental para garantir a triangulação 
das informações e consequente compreensão mais apurada dos usos do direito no movimento.

Por fim, no Capítulo 4, expomos nossas análises e conclusões desenvolvidas a partir das constatações apontadas nos capítulos anteriores, de modo a indicar como os diferentes usos do direito, ou mesmo o peso a ele conferido dentro das atuações estratégicas, podem ser indicativos dos rumos da luta pela Reforma Urbana. Por ser um capítulo de cunho eminentemente analítico das constatações apresentadas nos capítulos anteriores, as fontes utilizadas foram, no geral, as já mencionadas.

Com este trabalho, esperamos que, a partir da sistematização, análise e apontamentos aqui levantados, possamos ter subsídios para um debate sobre os rumos da Reforma Urbana no cenário de lutas mais atual no que tange à utilização do direito enquanto estratégia de luta, sabendo diferenciá-lo do cenário do período anterior e sabendo reconhecer suas potencialidades. 


\section{capítulo 1. o Direito na Reforma Urbana}

Iniciamos nossa pesquisa nos anos finais da década de 80, quando inaugurou-se no Brasil um período de lutas pela Reforma Urbana protagonizado por movimentos sociais, entidades populares, pesquisadores, profissionais e assessorias técnicas aglutinados principalmente em torno do Movimento Nacional pela Reforma Urbana (MNRU) e que caracterizou-se essencialmente por localizar a questão urbana no cenário político mediante a bandeira de luta da Reforma Urbana e por formular estratégias e práticas tendo em vista sua efetivação (SILVA, 1991). A importância desse período nas lutas dos movimentos sociais e no posicionamento da questão urbana enquanto pauta política popular é inegável e constituiu um vasto objeto de estudo para pesquisadores de diferentes campos do conhecimento.

Dentre muitos deles, especialmente aqueles que se propuseram a fazer um balanço sobre os avanços e limitações das lutas urbanas durante a Reforma Urbana, parece ser um consenso de que a aposta no campo jurídico-institucional foi uma marca das lutas pela Reforma Urbana levadas a cabo especialmente pelo MNRU e movimentos sociais a ele aglutinados (ver ARANTES, 2013; MARICATO, 2014, 2015) e que, como veremos, se traduziu especialmente pelo uso estratégico do direito voltado à elaboração legislativa, primeiramente direcionada aos direitos e, depois, aos marcos da política urbana.

Nesse capítulo, então, nos proporemos a analisar, de maneira contextualizada, a trajetória da aposta no campo jurídico-institucional na Reforma Urbana e da sua tradução no uso estratégico do direito mediante a elaboração legislativa, para ressaltar, especialmente, os rumos por ele implicados na luta pela Reforma Urbana no período. 
Dividiremos, então, este capítulo em três partes: na primeira, faremos uma breve introdução para apontarmos como que, durante o processo nacional constituinte vivenciado na década de 80, foi construída uma nova relação entre os movimentos sociais e o campo jurídico-institucional, que tornou-se objeto de disputa de muitos deles; então, na segunda, introduziremos como que a luta pela Reforma Urbana inaugurada neste contexto inseriu o campo jurídico-institucional nos seus horizontes estratégicos e o traduziu, inicialmente, em processos de elaboração legislativa como forma de realização de justiça social nos marcos da Reforma Urbana; por fim, na terceira parte, apontaremos como, ao longo dos anos, a proposta de elaboração legislativa direcionou-se à promulgação de leis que regulamentassem a política urbana.

\title{
Viver o pleno direito: o processo constituinte da década de 1980
}

\author{
"(...) É! \\ A gente quer viver pleno direito \\ A gente quer viver todo respeito \\ A gente quer viver uma nação \\ A gente quer é ser um cidadão \\ A gente quer viver uma nação... \\ É! É! É! É! É! É! É!" \\ (Gonzaguinha, "'É", 1982)
}

Se por um lado, a década de 80 no Brasil apresentava um quadro desolador de profunda retração econômica e precarização das condições de vida nos grandes centros urbanos, de outro, ela ostentava um cenário político ímpar de mobilizações sociais em torno da pauta da democratização (BONDUKI e KOWARICK, 1994; MARICATO, 1988, $2014,2015)$. Os movimentos sociais, que tinham emergido nas periferias urbanas durante a década de 70 e constituíam novas formas de organização da classe trabalhadora (SADER, 1988), juntaram-se às formas mais tradicionais de organização popular, como os partidos políticos e as entidades sindicais, e garantiram que a década de 80 fosse 
vivenciada a partir de um expressivo leque de forças sociais atuantes na vida política e resistentes às tradições autoritárias do poder político brasileiro, consubstanciadas em grande parte pelo Regime Ditatorial. É neste momento que importantes entidades populares, como o Partido dos Trabalhadores (PT), a Central Única dos Trabalhadores (CUT), o Movimento dos Trabalhadores Rurais Sem Terra (MST), a Confederação Nacional das Associação de Moradores (CONAM), a União dos Movimentos de Moradia (UMM) e o Movimento de Defesa dos Favelados (MDF), foram criadas, posteriormente reforçadas com o surgimento da Central de Movimentos Populares (CMP) e do Movimento Nacional de Luta pela Moradia (MNLM) (MARICATO, 2014).

Naquela época, o desejo de redemocratização política estava se generalizando nos espaços sociais do país. Em 1984, o gigantismo das mobilizações do movimento pelas Diretas-Já trouxe às ruas milhares de pessoas e "constituiu um marco no processo de construção da cidadania brasileira, perdida nos desmandos de um país sem legitimidade institucional" (MICHILES et al, 1989, p. 19).

De fato, se o regime ditatorial tinha formulado um arranjo institucional que utilizava mecanismos constitucionais e legais na infame tentativa de legitimar suas ações (ROCHA, 2013), tal legitimidade se esvaía diante da conjuntura econômica, social e política que o país enfrentava. Os mecanismos legais, como os Atos Institucionais e a Constituição de 1967, apesar de terem conferido poder ao regime ditatorial, já não eram suficientes para mantê-lo. Entretanto, seria impossível a criação de um Estado Democrático se tais mecanismos continuassem vigentes. Assim é que o próprio arranjo institucional do Regime Ditatorial apontou para a via constituinte como caminho necessário à redemocratização do país, já que esta estaria fadada ao fracasso caso fossem mantidas as normas constitucionais autoritárias e repressivas do período anterior (ROCHA, 2013). Nas palavras de Maricato (2014), neste período, "elaborar propostas e projetos de políticas públicas e reconstruir o Estado parecia não só viável como necessário" (MARICATO, 2014, p. 28 - grifos nossos).

Percebendo tal necessidade, a elite dirigente fez o que estava ao seu alcance para conter o momento político e limitar as mudanças institucionais às mais brandas possíveis ${ }^{5}$

\footnotetext{
${ }^{5} \mathrm{O}$ professor Antônio Sérgio Rocha, em seu artigo "Genealogia da constituinte: do autoritarismo à democratização" argumenta que o próprio arranjo institucional do regime ditatorial exigiu que a via constituinte fosse o caminho para a redemocratização do país e que, diante disso, as forças políticas foram traçando suas estratégias. A estratégia da elite de garantir uma transição constitucional a mais branda
} 
; os setores de esquerda, por outro lado, atentos à capacidade de criação de uma identidade coletiva de lutas em torno das pautas da democratização e da cidadania, fixaram-nas, como nunca antes feito, no centro de suas ações (MARICATO, 2014) - ainda que disso tenham sido construídas diferentes formas de atuação e estabelecidos diferentes graus de prioridades a partir das leituras de conjuntura política de cada movimento ou segmento de esquerda ${ }^{6}$.

Para uma sociedade que vivera mais de 15 anos em um contexto de arrocho de direitos, o momento da Constituinte tornou-se, então, um período de inflexão fundamental: era hora de construir um novo Estado Brasileiro, essencialmente Democrático, e de reivindicar os direitos sociais e de cidadania. E, na contramão da tradição constitucional brasileira, marcada por uma postura imperativa do Estado - já que das 6 (seis) Constituições Federais até então aprovadas, 3 (três) delas tinham sido outorgadas pelo Poder Executivo (1891, 1934 e 1967)7 , assim como também fora a Emenda Constitucional 01/1969 (que alterou substancialmente a Constituição Federal de 1967) -, as camadas populares começam a reivindicar seu direito à participação neste importante momento político do país (FERNANDES, 2010).

De início, os setores conservadores insistiam em incumbir a redação do novo texto constitucional a uma "Comissão de Notáveis" ${ }^{8}$ ou mesmo a um Congresso Constituinte

possível passou também por embates no campo institucional, como fica ilustrado nesta passagem: "No plano institucional, entretanto, os membros da cúpula da Aliança Democrática operavam para manter sob controle o processo de construção constitucional. A emenda convocatória da ANC [Assembléia Nacional Constituinte], instituindo um Congresso Constituinte em bases derivadas da Constituição Federal de 1967, foi agenciada pelo ramo pefelista do consórcio político. Do lado do PMDB, Ulysses Guimarães interviria decisivamente para abortar a proposta de plebiscito sobre a questão, tal como previsto no substitutivo elaborado por um relator defenestrado pessoalmente pelo grande timoneiro da transição. Por fim, o próprio presidente Sarney tentaria legar ao esquecimento das gavetas do Ministério da Justiça o meticuloso e progressista Anteprojeto Constitucional da Comissão Arinos." (ROCHA, 2013, s/pag.)

${ }^{6}$ É importante ressaltar tal fato, pois, apesar dessa conjuntura política nacional colocar no centro da pauta política o processo de redemocratização e elaboração constitucional, cada movimento e setor da esquerda tinha sua leitura e avaliação de conjuntura, de maneira que as atuações no processo institucional foram diferentes.

7 A constituição de 1967 foi apresentada como se semi-outorgada fosse (1967), pois, em termos essencialmente formais, foram os representantes diretos do povo, no Congresso Nacional, que teriam a promulgado; entretanto, os ditames dos militares foram tão explícitos no texto constituinte que, na prática, restam poucas dúvidas quanto ao seu caráter outorgado.

${ }^{8}$ Vale pontuar que a formação de uma "Comissão de Notáveis", cuja função era elaborar um anteprojeto de Constituição, foi uma proposta de Tancredo Neves altamente criticada à época, em razão do fundado receio do produto ser demasiadamente alinhado aos interesses do governo - e da classe que o dirigia. Entretanto, ao final dos trabalhos da referida Comissão, o anteprojeto apresentado revelou-se muito interessante na medida em que trabalhava pontos fundamentais, como o papel das forças armadas. Não por outro motivo, 0 
tendencioso ${ }^{9}$, que chegou a ser eleito em 1986 (SILVA, 1991). Entretanto, foi a articulação dos Plenários Pró-participação Popular na Constituinte por movimentos e entidades sociais participantes do Movimento Nacional pela Constituinte que garantiu a pressão política necessária à mudança, em março de 1987, no regimento interno da Constituinte, tornando legítima a iniciativa legislativa popular por meio da apresentação e defesa de emendas ao projeto da Constituição. Este talvez tenha sido um fator desencadeador de um dos pontos altos da participação política popular deste período, traduzido por meio de nada mais nada menos que 12 milhões de assinaturas a projetos de emendas populares relacionadas aos mais diferentes temas (SILVA, 1991). Tal número, apesar de percentualmente limitado face ao total da população brasileira à época, é simbolicamente expressivo quando compreendido no contexto de um país de tradições autoritárias e patrimonialistas que ainda hoje reproduzem um movimento de apropriação do Estado, de suas instituições e de seus ordenamentos pela elite como se privados fossem - e que historicamente reagem com violência às tentativas de mudanças que possam minimamente alterar seu status de dominância.

Os movimentos sociais começam então a disputar a cena pública reivindicando direitos, a começar pelo direito a reivindicar direitos (SADER, 1988), que traduzia a demanda pelo reconhecimento do seu status de cidadão e o estabelecimento de uma nova relação política do e com o Estado. A noção de cidadania, neste sentido, passa a ser uma orientação muito presente nas lutas políticas neste contexto.

Vale ressaltar que a noção de cidadania, de acordo com Boito Junior (2007), decorre dos processos políticos desenrolados no âmbito das revoluções burguesas, quando não apenas o ideal de igualdade jurídica formal foi estabelecida entre todos os habitantes de um mesmo território mas também quando os Estados-Nação, munidos de instituições universalistas, sobrevieram aos estados dinásticos. A cidadania representaria, então, um momento de ruptura no qual, a partir do estabelecimento do modo de produção capitalista, "os trabalhadores deixaram de ser propriedade absoluta (escravo) ou limitada (servo) do proprietário" e "adquiriram independência pessoal,

anteprojeto foi alvo de uma intensa campanha negativa por parte dos setores mais conservadores e, apesar de ter influenciado alguns pontos da Constituição Federal aprovada em 1988, perdeu notoriedade. Para mais, ver MICHILES et al, 1989.

9 A Assembleia Constituinte eleita em 1986 era alvo de diversas críticas quanto a sua idoneidade, representatividade e independência, conforme aponta MICHILES et al, 1989. 
assegurada pelos direitos civis mínimos que são a base da cidadania, passando a constituir uma classe de trabalhadores como nunca existira na história" (BOITO JUNIOR, 2007, p. 254). À classe trabalhadora, então, a noção de cidadania aparentemente revelaria não apenas o seu reconhecimento formal pelo Estado ao se tornar sujeito de direitos mínimos, mas também sua legitimidade de construir tal Estado e a reivindicá-lo, já que este não mais estaria sob o monopólio particular de determinado estamento.

Neste sentido, a noção de cidadania guarda uma relação intrínseca com o Estado, pois ela somente se concretiza enquanto status quando o Estado reconhece os sujeitos que a pleiteiam e legitima suas ações. Assim, se talvez em um primeiro momento, este foi um caminho importante inclusive de afirmação da identidade política de diversos movimentos e setores sociais, é preciso ressaltar que foi também um caminho que indicava a centralidade do Estado e do seu reconhecimento institucional como medidas de legitimação social. De qualquer maneira, é inegável que este processo de luta popular na Constituinte abriu novas frentes de luta política antes desconhecidas pelos movimentos sociais.

"A configuração de uma nova cultura política que se expressa de maneira significativa nos anos 85/86, quando amplas forças populares se mobilizaram na elaboração e debate de emendas à Constituinte Federal, trouxe para o palco da cena principal outras formas de fazer política onde os mecanismos de representação e negociação, a questão da construção de novos direitos e da participação tanto na elaboração da lei quanto na gestão democrática das cidades, adquiriram maior visibilidade no seio de um debate cada vez mais significativo sobre as formas de articulação entre democracia direta e representativa." (SILVA, 1991, p. 27 - grifos no original)

Uma vez conquistada a possibilidade de apresentar Emendas Populares ao projeto da Constituição, as camadas populares, então, se organizaram para atuar no espaço da elaboração, discussão e negociação legislativa constitucional, um campo que lhe era praticamente desconhecido. Pela primeira vez, tal espaço começou a ser preenchido por 
forças populares, que passaram a disputar seu ideal de Estado, de cidadania e de uma sociedade de direitos. A Constituinte, então, conforme apontado na obra "O cidadão constituinte: a saga das emendas populares", organizado por Carlos Michiles (1989), representou um processo político de cunho profundamente pedagógico no sentido da construção do ideal de cidadania brasileira e da emergência das camadas populares como sujeitos nos embates institucionais decisivos. De fato, tal processo inaugura a participação popular tanto no seio da elaboração constitucional quanto no âmbito institucional mais geral e introduz o campo jurídico-institucional como novo espaço de disputa social.

Desenvolve-se, daí, um novo significado nas relações entre os movimentos sociais inseridos neste processo constituinte e o campo jurídico-institucional (SILVA, 1991). Movimentos sociais, entidades populares e partidos políticos elaboraram propostas constitucionais voltadas à garantia de direitos e proteção de diferentes segmentos das camadas populares, como foi o caso dos movimentos de mulheres, que apresentaram 4 (quatro) propostas de emendas constitucionais relativas aos direitos, à saúde e a aposentadoria das mulheres; dos trabalhadores rurais, com as propostas pela Reforma Agrária; dos movimentos urbanos, com a Emenda Popular pela Reforma Urbana; e dos movimentos de saúde, com suas 6 (seis) propostas de emendas constitucionais.

Ao Direito, consubstanciado neste momento pelas disposições constitucionais, começa a ser projetado um imaginário de instrumento de concretização de avanços sociais, quando formulado a partir e de acordo com a vontade do povo e assim materializado na forma de legislação:

"Eles [ os pobres, os trabalhadores ] sabiam perfeitamente; tinham aquela noção de direito: 'Ah, eu vou correr atrás dos meus direitos'. Isso é fruto de todos esses anos; eles tinham muita clareza de que na Constituinte - coisa que não se tinha na classe média - que na Constituinte estariam os novos direitos dos trabalhadores. Porque é gente que veio das lutas, das greves de 1977/78/79. E que viu que, pela correlação de forças, tinham tido algumas vitórias, mas não conseguira tudo. Se vocês consultarem os documentos do pessoal militante da época, era isso. Querem 
ver outro slogan que havia, e que era dos mais fortes? 'A luta faz a lei'. E por que a lei é importante? A lei é importante porque ela vai definir os seus direitos" (entrevista com Maria Vitória Benevides in BRANDÃO, 2011, p. 54 - grifos nossos).

Neste sentido, o Direito, mais do que nunca e especialmente pelas classes populares, começa a ser entendido como um instrumento de potencial realização da democracia e da justiça social ao passo que o campo institucional se torna um importante meio para a disputa do Direito ou de políticas que o efetivassem. Desse novo entendimento, novas ações políticas emergiram, já que a dinâmica do campo jurídico-institucional demandava dos movimentos sociais a compreensão de uma nova lógica, permeada pela articulação com partidos políticos e parlamentares, pela submissão das ações aos tempos políticos da Assembléia Nacional Constituinte, pela prática de advocacy $^{10}$ em conjunto com outras forças sociais e econômicas, entre outros. A luta por novos direitos, pela cidadania e pelo Estado, neste contexto, implicou na centralização da luta política nas instâncias constitucionais, onde os mecanismos de representatividade e negociação de direitos tornaram-se fundamentais (SILVA, 1991).

Assim, o sentido das lutas sociais da década de 80 ficou marcado pela ascensão de uma cultura política nova, que posiciona o campo jurídico-institucional como espaço de disputa política às camadas populares e que inaugura uma nova relação entre os movimentos sociais e tal campo. Esta era uma compreensão da luta política mais geral da época. Vejamos agora como isso se deu particularmente no âmbito da questão urbana e como que as lutas pela Reforma Urbana foram influenciadas, também, por essa compreensão.

\footnotetext{
${ }^{10}$ Aqui, advocacy é empregado no mesmo sentido de lobby, embora este traga sentidos pejorativos. Buscamos nos referir à prática profissional de incidência de grupos de interesses nos processos decisórios - seja no processo legislativo, seja na construção de políticas públicas ou no monitoramento de sua implementação com vistas à consecução de suas pautas.
} 


\section{A Reforma Urbana nos marcos da cidadania}

É neste contexto social, político e jurídico que a Reforma Urbana volta à seara dos debates públicos, depois de ter sido interrompida no início da década de 60 , quando fora elaborada pela primeira vez nos encontros organizados pelo Instituto dos Arquitetos do Brasil (IAB) em meio ao contexto das propostas de Reformas de Base do Governo João Goulart em 1963 (MARICATO, 2014, 2015; SANTO AMORE, 2013). Com o Golpe Militar em 1964, a proposta da Reforma Urbana acabou sendo lentamente apropriada e distorcida pelo Governo Ditatorial, que aplicou-a "pelo avesso, constituindo um aparato institucional tecnocrático, fortemente centralizado, de política habitacional, de transporte e de saneamento, ignorando a questão fundiária." (MARICATO, 2010, p. 17). Assim, se durante os primeiros anos da década de 60 criou-se a ideia de Reforma Urbana, os anos seguintes trataram de descaracterizá-la e burocratizá-la.

$\mathrm{Na}$ década de 80, no entanto, a Reforma Urbana não foi apenas retomada mas aprofundada a partir de uma chave progressista que passou a entendê-la como "(...) um conjunto articulado de políticas públicas, de caráter redistributivista e universalista, voltado para (...) reduzir os níveis de injustiça social no meio urbano e promover uma democratização do planejamento e da gestão das cidades" (SOUZA, 2013 apud DENALDI, BRAJATO, SOUZA, FROTA, 2017, p. O2). Os sujeitos que a reivindicavam também aumentaram: diferentemente da proposta da década de 60, voltada a um campo muito mais intelectual da arquitetura, a retomada da Reforma Urbana na década de 80 tinha um caráter propriamente social (TANAKA, 2017) e consolidou-se como uma verdadeira bandeira de luta dos setores progressistas que vinham posicionando a questão urbana em um novo patamar teórico e político desde a década de 70. Vale a pena, aqui, fazer uma breve digressão de como a produção acadêmica crítica sobre o fenômeno urbano e as práticas reivindicativas dos movimentos sociais urbanos, ambas iniciadas durante a década de 70, e as experiências nas 'prefeituras democráticas e populares', já nos anos 80, foram fundamentais neste processo de posicionamento da questão urbana enquanto questão política (MARICATO, 2014). 
No que tange à mencionada produção acadêmica, nos referimos aos estudos iniciados na década de 70 por autores como Francisco de Oliveira, Lúcio Kowarick e Ermínia Maricato, cuja análise enfatizava a produção do espaço urbano no Brasil sob a chave da sua condição periférica no capitalismo global (MARICATO, 2014). Na época, as cidades brasileiras, historicamente caracterizadas por uma desigualdade social e exclusão sócio-espacial profunda, tornaram-se ainda mais desiguais. A cidade 'oculta', aquela construída à margem das legislações e do mercado imobiliário formal, não apenas cresceu em termos reais, mas se tornou objeto do olhar de pesquisadores e acadêmicos (ARANTES, 2013), de maneira que "uma nova consciência sobre o universo da informalidade, da segregação, da pobreza" ganhou dimensão (MARICATO, 2014, p. 112), pois percebeu-se que são necessárias ao processo de acumulação capitalista na seara urbana. Assim, de meros efeitos das condições econômicas gerais, as dinâmicas do urbano ganharam novos sentidos e passaram a ser entendidas como uma questão fundamental à compreensão dos mais recentes processos capitalistas de produção.

Aliado a isso, os moradores de favelas, cortiços, loteamento irregulares obviamente os mais afetados pelo aprofundamento do crescimento urbano desigual das cidades brasileiras - passaram a se organizar naqueles que representaram uma nova configuração política das classes populares no cenário público: os movimentos sociais (SADER, 1988). Tais movimentos se organizavam territorialmente, reivindicavam melhores condições de vida e habitabilidade, se caracterizavam por apresentar um caráter fragmentado - eminentemente reivindicativo e territorializado - e, em razão da sua autonomia e fragmentação, se consolidaram como “(...) formas autônomas de expressão de diferentes coletividades" (SADER, 1988, p. 198) que tinham o condão de levar a cabo processos necessários de transformação social. Neste sentido, seu surgimento no cenário político brasileiro era visto com entusiasmo, quando não como uma promessa de futuro. Durante a década de 70 , de fato, tais movimentos protagonizaram as reivindicações urbanas e trouxeram à tona - ainda que de maneira pontual e territorializada - a questão urbana como uma pauta mobilizatória e organizativa.

Entretanto, se eles foram atores fundamentais na construção de uma nova identidade de sujeitos políticos e na constituição de governos locais democráticos (MARICATO, 2014), já nos últimos anos da década de 80, suas fragilidades e limitações 
ficaram evidentes ${ }^{11}$, dentre as quais se destaca a dificuldade de inserir a pauta habitacional e urbana no cenário público e político mais geral. Essa pauta, por sua vez, obteve maiores ecos quando do agravamento das condições de vida urbana, que expandiu seus efeitos nefastos para a classe média, ao longo dos anos 80 . Foi somente assim que uma ideia de crise habitacional começou a ser desenhada - ainda que os movimentos sociais e pesquisadores acadêmicos já a denunciassem há tempos - e sua evolução progressiva começou a ser objeto de debate no bojo da opinião pública, de maneira a possibilitar uma limitada conscientização sobre o tema e uma (re)aproximação de setores técnicos e profissionais, sobretudo da classe média, das áreas de arquitetura, urbanismo, geografia e direito - além dos pesquisadores universitários, já mencionados -, com a questão (MARICATO, 1988). Tal aproximação fora notável neste período e se consolidou no sentido de trazer contribuições teóricas e técnicas às questões enfrentadas diariamente pelos movimentos sociais urbanos (SILVA, 1991).

Assim foi que, ao longo dos anos 70, às práticas de lutas dos movimentos sociais aliou-se uma nova interpretação teórica e empírica sobre a questão urbana, de maneira a se influenciarem mutuamente. Aos poucos, foi sendo construído um entendimento de que a cidade precisava não só ser vista como um todo, mas também assim reivindicada. Dessa forma, já nos primeiros anos da década de 80, foi se consolidando a "idéia de cidade, a cidade de todos, a casa além da casa, a casa com asfalto, com serviços públicos, com escola, com transporte, com direito a uma vida social." (SAULE JUNIOR e UZZO, 2010, p. 260).

Tal entendimento foi, posteriormente, acolhido e reforçado pelas 'gestões democráticas e populares' (MARICATO, 1988, 2010, 2014, 2015), que já no final dos anos 80 se disseminaram nos municípios brasileiros e que, sendo lideradas por partidos progressistas (notadamente o PT), adotaram uma política de inversão de prioridades (MARICATO, 1988, 2010, 2014, 2015; ARANTES, 2013), constituindo o 'novo urbanismo democrático-popular' (ARANTES, 2013).

\footnotetext{
${ }^{11} \mathrm{O}$ fechamento político que conduzia a um isolamento em relação a outras forças sociais; o direcionamento de suas práticas à pressões específicas aos órgãos públicos; a desconfiança nas formas de representação; e o distanciamento das formas mais institucionalizadas de fazer política; todos estes eram fatores que, entre outros, indicavam as referidas limitações dos movimentos sociais constituídos na década de 70. Para mais, ver TELLES in KOWARICK, 1994; TELLES, 1987; SILVA, 1991.
} 
Então, os primeiros anos de constituição da agenda da Reforma Urbana - dado nos anos 80 e início dos anos 90 e inserido no contexto de lutas e construção de um novo olhar político para o urbano - encontrou na luta pela redemocratização e pela promulgação de uma nova Constituição o amparo e as condições para a retomada do seu ideal enquanto uma bandeira de luta progressista, menos restrita às reivindicações parciais e localizadas, anteriormente levadas a cabo pelos movimentos sociais, e mais voltada a uma concepção universalista do direito à cidade e de justiça social no espaço urbano (SILVA, 1991). Recuperá-la, ainda mais nestes termos e após tantos anos de esquecimento, disseminava um clima de entusiasmo (MARICATO, 2014), ainda que, mesmo nos setores de esquerda, tal pauta não fosse vista como prioritária; foi de fato um processo longo para que a questão urbana fosse mais aceita enquanto uma condição fundamental para a democratização da sociedade brasileira (SAULE JUNIOR e UZZO, 2010), que não poderia ser inteiramente resolvida a partir das bandeiras de lutas do campesinato e do operariado - historicamente as duas forças mais destacadas das lutas populares (MARICATO, 1988). Ainda assim, parece ser consenso na literatura especializada que o processo constituinte foi o marco da reinauguração da pauta da Reforma Urbana e da convergência das lutas sociais urbanas em torno das pautas mais amplas e práticas unificadoras conduzidas pelo MNRU (MARICATO, 2014, 2015; SAULE JUNIOR e UZZO, 2010; SILVA, 1991; TANAKA, 2017).

Este fato - da Reforma Urbana ter sido reinaugurada durante os processos de lutas pela redemocratização e durante a Constituinte - parece ser fundamental para compreendermos o contexto a partir do qual a elaboração de direitos urbanos enquanto direitos de cidadania emergiu como estratégia política nos primeiros anos de atuação do MNRU (SAULE JUNIOR e SILVA, 1993).

"Mistura de utopia com plataforma de unificação de movimentos, a bandeira da Reforma Urbana, na sua origem, não se resume tão somente à questão da politização do urbano, através da tematização da segregação e exclusão social no espaço das cidades. À questão da justiça social, implícita no discurso sobre o conteúdo da Reforma Urbana, somam-se os valores da igualdade e da cidadania demandando a criação de novos direitos básicos à 
Cidade. Com isso, visa-se romper com a preservação de privilégios no acesso ao espaço das cidades, privilégios estes que sempre encontraram apoio no marco legal existente no país." (SILVA, 1991, p. 09 - grifos nossos)

À época, entendia-se por direitos urbanos o acesso universal tanto aos equipamentos e serviços básicos quanto aos espaços de gestão democrática das cidades (SILVA, 1991); partia-se, então, da ideia de que quanto mais acesso à moradia, serviços de saneamento, energia elétrica, transporte público, educação, saúde, menos desiguais seriam as condições de vida nas cidades e, por isso, mais justas elas seriam. A justiça estava ligada, portanto, ao direito de acesso igualitário aos espaços públicos, e, uma vez realizada, afetaria não apenas a constituição das cidades brasileiras, mas também uma escala mais ampla de sociedade. Neste sentido, os direitos urbanos reivindicados pelo MNRU foram elaborados enquanto uma expressão dos direitos de cidadania (SILVA, 1991; SAULE JUNIOR e SILVA, 1993; SAULE e UZZO, 2010), vez que partiam do entendimento de que a cidade constitui de tal maneira da vida social que sua democratização significaria a própria democratização da sociedade, ou, em outras palavras, a justiça urbana seria componente fundamental da realização da justiça social. A promulgação de direitos urbanos, neste sentido, seria uma estratégia fundamental para a realização da Reforma Urbana - e especialmente dos seus princípios de justiça urbana.

Nos parece, neste sentido, inegável o diálogo entre a estratégia da elaboração de direitos adotada neste primeiro momento do Ciclo da Reforma Urbana e o cenário político de mobilização, em âmbito nacional, dos movimentos sociais que reivindicavam o direito a ter direitos (SADER, 1988) ou os direitos de cidadania. Ao fomentar tal diálogo, o MNRU e os movimentos sociais urbanos que protagonizavam a agenda da Reforma Urbana colocaram no centro do cenário político a possibilidade de uma ampliação do conceito de cidadania (SAULE JUNIOR E SILVA, 1993) que envolvesse o acesso aos elementos dos direitos urbanos, de maneira a romper não apenas com um ideal técnico e cientificista de planejamento urbano muito em voga nas décadas de 60 e 70 no Brasil - um ideal que não raro também se fazia autoritário, ao excluir do processo de elaboração qualquer iniciativa da população não técnica (SILVA, 1991) -, e também com o próprio caráter do direito no 
âmbito urbano - até então eminentemente administrativo, voltado ao exercício da regulamentação procedimental de temas como o parcelamento, uso e a ocupação do solo.

A elaboração de direitos, neste sentido, foi se consolidando enquanto estratégia de realização da justiça social nos marcos da Reforma Urbana. E, nos moldes das ações do MNRU, tais direitos seriam, ao fim e ao cabo, traduzidos em formato oficial por meio da sua positivação, de forma a ajudar a embasar a construção de um novo marco legal para as cidades brasileiras:

"(...) nasce no seio das lutas sociais dos movimentos populares urbanos uma demanda por reconhecimento de direitos, de origem popular, como o direito à cidade e o direito à moradia. Estes direitos passam a ser institucionalizados no campo das leis urbanas, a partir da demanda das organizações e movimentos populares, que passam a conquistar políticas, projetos e instâncias democráticas de participação no âmbito da organização política e jurídico-institucional do estado brasileiro." (SAULE JUNIOR e $\mathrm{UZZO}, 2010$, p. 265)

Assim, a partir da necessidade de tradução das lutas na forma de direitos de cidadania e de reivindicação da sua oficialização pelo Estado, foi imposto aos juristas o desafio de "'criarem uma nova legalidade para as conquistas obtidas através das lutas populares'. Sua maior atenção passou a ser a questão de como construir uma 'ordem alternativa legítima', baseada em uma nova representação da vontade coletiva, que pudesse legalmente, proporcionar um novo contrato político." (PAOLI, 1990, p. 23 apud SAULE JUNIOR e SILVA, 1993, pg.59). Foi ganhando importância, também ao MNRU e demais movimentos sociais que protagonizaram a cena política à época, o conhecimento da esfera institucional brasileira, seus tempos, dinâmicas e procedimentos, além da própria lógica da legislação, seus artigos, linguagem e melindres. Neste sentido, na esteira do cenário político mais geral do país, o MNRU passou a ressignificar o campo jurídico-institucional enquanto espaço importante de incidência política.

Teria, assim, sido constituída pelo MNRU "'uma nova forma de luta política' no âmbito das lutas urbanas, voltada para a institucionalização de novos direitos baseados na 
noção de justiça social 'através de novas relações entre movimentos sociais e o plano jurídico-institucional"' (TANAKA, 2017, p. 81-82). Dessa forma, a concepção do MNRU trouxe uma mudança fundamental nos rumos das lutas urbanas travadas até então:

"Tanto a questão da unificação e articulação das lutas e reinvidicações, como os direitos urbanos e direitos de cidadania que emergem através de uma outra instância de participação - a instância jurídico-institucional - diferenciam movimentos como este de Reforma Urbana e outros, dos movimentos da década de 70. Aqui a linguagem dos direitos, que permeia todo o discurso da Reforma Urbana, transforma em prática social dos movimentos a tarefa de entender a lei, decodificá-la, elaborar artigos e, principalmente debater e discutir a lei. Além dessa linguagem dos direitos expressar o reconhecimento da capacidade de julgamento e decisão das classes populares, inclusive na tarefa de elaboração e debate das leis, transforma a esfera jurídico-institucional em um novo lugar de onde se desdobra a luta política, onde novos direitos poderão ser debatidos e negociados." (SILVA, 1991, p. 29 - grifos no original)

Vale ressaltar, ainda, que o caráter mais amplo da estratégia de elaboração dos direitos urbanos garantiu uma inédita e significativa unidade entre os movimentos sociais urbanos, os quais, durante toda a década de 70, promoveram lutas de caráter fragmentado e territorializado. Assim, tal estratégia não só foi fundamental para direcionar as lutas pela Reforma Urbana, mas também para consolidar um espectro de sujeitos sociais unidos na luta política por tal bandeira.

Assim é que, em 1987, a Emenda Popular da Reforma Urbana foi subscrita por mais 150 mil assinaturas provenientes das mais diferentes regiões do país e defendida na Comissão de Sistematização da Constituinte pela Profa. Erminia Maricato. Como resultado dessa mobilização em torno da referida Emenda, foi inserido no texto constitucional um capítulo sobre Política Urbana, o qual, mesmo reduzido a dois artigos, foi interpretado como um marco fundamental desse período de lutas e como uma vitória, 
ainda que parcial, dos movimentos sociais urbanos e do MNRU. Questões como a usucapião especial urbana, a função social da cidade e da propriedade, além da previsão do parcelamento, uso e edificação compulsórios - todas dispostas no texto constitucional, porém cada qual com seu grau de auto-aplicabilidade - geraram expressivas repercussões na opinião pública. Os recortes de jornais da época, transcritos abaixo, mostram algumas delas:

"Para se ter uma ideia da repercussão de sua adoção, basta observar que todos os moradores das favelas do Rio poderão de um dia para o outro, após a promulgação da nova Constituição, entrar na Justiça para reivindicar o domínio do imóvel onde mora, mesmo que pague aluguel por ele. (...) A partir da vigência da nova Constituição, com esse artigo do usucapião, ficará definitivamente sepultada a política de remoção de favelas. (...) Se quiser remover os favelados beneficiados com a novidade constitucional, a prefeitura não poderá mais tratá-los como cidadãos de quinta categoria, como são tratadas até agora as famílias removidas. Da nova Constituição em diante, eles poderão passar a ser proprietários - e nessa condição, qualquer política de remoção passará a incorporar um ingrediente novo, a indenização do barraco que se pretende demolir." (Jornal do Brasil, 03 de maio de 1988 - "Constituinte revoluciona cidades com posse do imóvel" in SILVA, 1991 - grifos da autora) 


\section{No Rio, 1,8 milhão devem ser beneficiados}

$\mathbf{M}_{\text {soas vivem hoje, nas } 600 \text { ta. }}$ ais de très milhões de pes. velas e corticos do Rio de Janeiro. Destas segunco dados da Secrota ria Estadual de Assuntos Fundía. ríos, pelos menos 1,8 milhăo deverá beneficiar-se, imediatamente, da decisáo da Constituinte que redu. zilu de 20 para einco anos a prazo que dá direito ao usucapiāo urbano, Entusiasmado, o Subsecretário Vicente Loureiro, acredita que a decisão representará a democrati. zaçáo da moradia nas grandes cictades.

- Quantas pessoas, nas grandes cidades, conseguem ter uma casa própria? Tenho certeza de que essa decisão da Constituinte, que proc: sa vir acompanhada uma mator mobilidade dó Poder Judiciário, irá mudar totalmente a situacäo.

Vicente fica tenso ao falar da Justica. Ele ressalta que, em mé cia, um favelado espera de dez a 15 anos para obter uma resposta so.

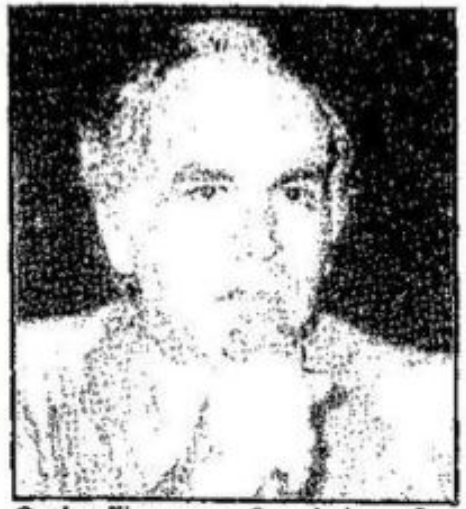

Carlos Flrme prevé mais invasōes

bre seu pedido de usucapiẫ. Mułtas vezes morre sem saber se era cu nảo dono do terreno.

Apesar do entusiasmo com a de. cisăo da Constituinte, Yicente prevê dificuldadades. For exemplo $\mathrm{um}$ sigrificativo aumento das invasčes de terras, principalmente em Jaca. repaguá, que ele aponta como a re. gano mais procirada pelos desabri. gados nos últimos dois anos,

O Presidente da Associacão de Dirigentes des Empresas do Merca. do Imobiliário (Ademi), Carlos Eirme, concorda com o Subsecretáría quanto a este ponto. Ble entende que a decisão da Constituinte acirrará os conflitos e disputas em diferentes áreas da cidade e trará preocupações aos proprietarios de terrenos urbanos da periferia.

Já para o Díretor Jurídico da As. sociação Brasilejra das Administradoras de Imóveis (Abadi), Ró. mulo Cavalcante Motta a solucẫo ê a desapropriacảo e distribuíçáo de lotes pelo Governo.

- Assim o Governo se encarre. garia de promover a urbanizaçăo das favelas e a remocâa das familias quo hoje vivem om áreas do risco - disse Motta.

Recorte de artigo sobre a Usucapião e seus eventuais impactos.

Fonte: Jornal O Globo, Rio de Janeiro, 08/05/88, p. $18^{12}$

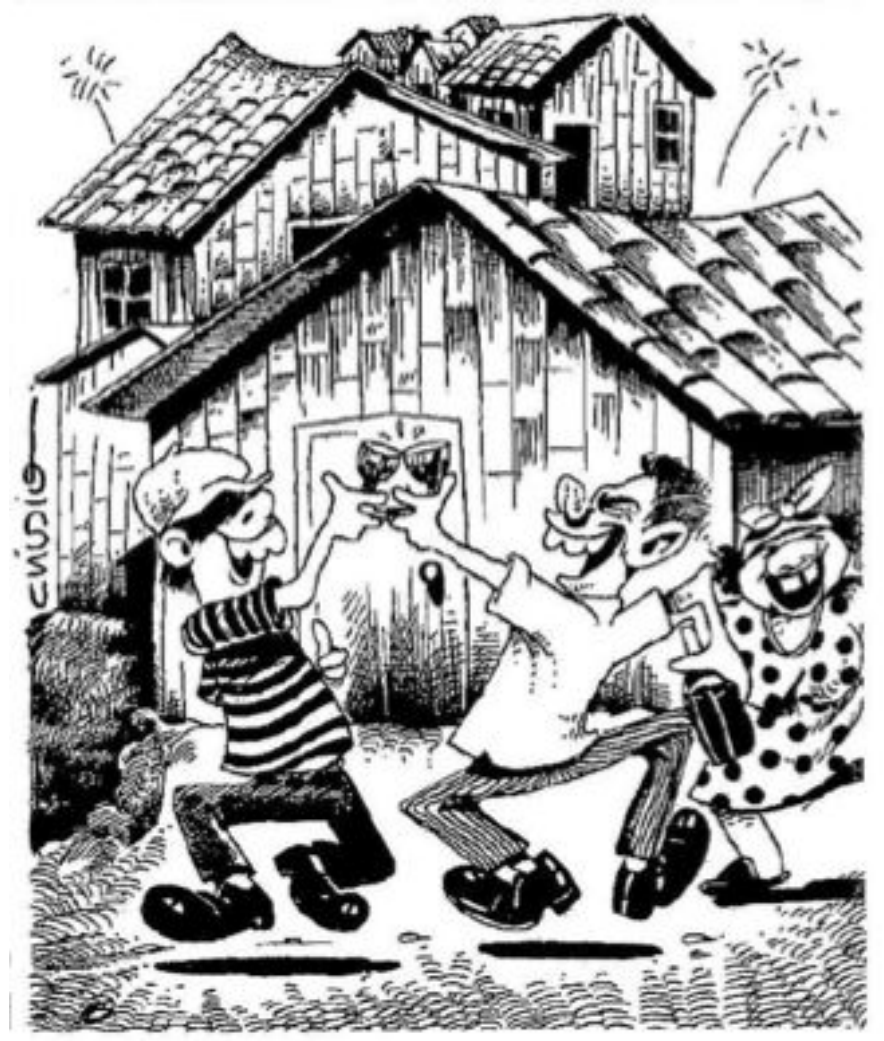

Charge do Jornal O Globo, que mostra os favelados comemorando a promulgação da Constituição de 1988 e o direito ao usucapião com novas regras.

Fonte: Jornal O Globo, Rio de Janeiro, 08/05/1988, p. 18.

${ }^{12}$ Acervo Digital O Globo <http://acervo.oglobo.globo.com/>. Acesso em 26/08/2017. 


\section{Juristas temem conflitos com nova política urbána}

A nova politica urbana aprovada segunda-feira pela Constituinte e incompleta e podera provocar, em todo o Pafs, mais problemas que beneffcios, segundo expectativa de advogados e furistas. Gofredo da Bilva Teles, professor emérito da Faculdade de Direito da USP, năo tern dưvidas: "Com o texto mal definido, qualquer um podera invadir uma área e dizer que é dele. Ė a pregaçăo da aniqullaçâo da proprie dade. Um texto como esse pode ser responsável pela alavanca da de sordem".

O texto da nova politica urbana diz que o dono de uma área "subutilizada" tera de promover seu adequado aproveitamento para năo ser ameaçado, por exemplo, por uma desapropriaçăo. "Subutilizado" uma expressão muito generica que se pode referir ate a imoveis com dois andares em áreas que o zoneamento permite a contruçăo de quatro pavimentos. "Isso ê um absur. do", reage o protessor Gotredo, "ha muitas expressōes, como essa, usadas de modo abusivo"

Ele se sente "alarmado" com o uso de palavras "que têm o colorido de expressőes juridicas, mas que so ser. pm para propaganda demagónica de urma sérle de idéfas năo perfeitamente es:abelecidas". cita, tamjêrr. outro exemplo, a expressão
"Interesse soctal" - um termo que "precisa ser muito bern definido sob pena de ser causa de maiores injus tiças e iniquididades".

Para que se adquira o dominio de um imóvel, pela nova legisiaçâ, será necessário ocupa-lo como moradia e obedecer a algumas exigên. cias, como năo possuir outra propriedade e estar instalado em um terreno com ate 250 metros quadrados. Douglas Filipin da Rocha, advogado especialista em Direito imobillário, diz que para reivindicar dominio de um imovel na Justlça "é necessárto provar a sua posse, o que é felto atraves de documentos ou testemunhas que indiquem o local como sua residência". Corn essas evidènclas, o fuiz poderá se convencer e conceder a posse do imovel.

Douglas Fulpin esclarece tambêm uma dûvida que existia, ate agora, no novo texto da politica urbana: o usucapiảo ê retroativo. Isto e, quando a Constituinte for aprova. da, os interessados poderăo entrar na Justica e pedir o dominio dos imovels. Um esclarecimento do ad vogado: "O proprietarto legal da area tamberm sera chamaco a jufzo para provar que ele ainda \& seu dono e que cuidava dela, contestando a aça do irvasor".

Outro advogaco, Carlcs Erzas. especiallsta em desaproprtaçces. defende opinião sobre o mesmo tema: "Ninguém quer resolver o problema da habitaçấo no Brasil. Os governantes brasileiros estăo apenas interessados em promover obras que rendem votos e gordas comissỏes. Como construir moradias nāo atendem esses dois requisttos, entảo o probiema continuará por mutos anos".

Ergas acha que a nova tegistaçăo de usucapiāo vaf incentivar ainda mais a ocupaçăo flegal de terrenos. "Esse texto foi feito muito mais para legalizar favelas." Segundo ele. ha outros meios, mais eficientes, de acabar com a especulaçăo imobilia ria e reduzir o defficit habitacional, a como impor impostos elevados areas desocupadas, o que, por coincidêncla, também está previsto na polftica urbana aprovada pela Constituinte.

Eros Roberto Grau, professor de Direito Econômico da USP, considera a nova legislação "um avan. co" por condicionar o uso da pro priedade as exigencias da ctdade.

"Mais que a institucionaltzaçăo do planejamento é o reconhecimento que o bem-estar da população e a qualidade de vida extgemo aprove: tamerto racional das areas uriaras tamenso racional das areas ur jarna

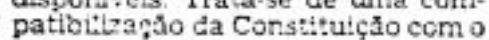
tempo em que tremos.

Fonte: O Estado de São Paulo, $n^{0} 34720,05 / 05 / 88$, p.20

Dos recortes selecionados vale a pena destacar como eles evidenciam opiniões discrepantes sobre o capítulo da Política Urbana aprovado na Constituição. O primeiro trecho selecionado traz um olhar bastante mistificado para as normas constitucionais, como se elas tivessem o condão de, de um dia para o outro, reverter processos sociais históricos - como é o caso da política de remoção de favelas. Nele, nos chamou atenção a referência ao fato de que, com as normas constitucionais, o poder municipal não poderia mais tratar os moradores de favelas como "cidadãos de quinta categoria". Entretanto, mesmo que nos anos 80 e 90 tenha sido disseminado o olhar de que a maioria das favelas eram formadas por trabalhadores (MARICATO, 2014), a associação de tais moradores à criminalidade ainda hoje é recorrente. Isso fica claro na charge reproduzida acima, na qual tal correspondência é explícita na figura do personagem à esquerda, vestido com o 
tradicional traje listrado do cárcere e com o rosto coberto. Se, a primeira vista, a charge parece representar apenas os favelados comemorando a garantia dos seus direitos por meio da usucapião constitucional, a referência ao criminoso representa uma crítica ferrenha ao instrumento da Usucapião, como se ela fosse um salvo-conduto aos ladrões de terras.

Caberiam ainda muitas outras observações sobre os recortes selecionados, porém, certamente a principal questão que se quer levantar é a de que, ainda que com posicionamentos díspares em relação às normas constitucionais, todos os recortes pressupõem uma potência transformadora do direito, ainda mais aquele constitucionalmente previsto, no que tange à realidade urbana das grandes cidades brasileiras. Seja pelo incentivo às ocupações urbanas, pelo súbito fim das políticas de remoção de favelas, pelo aniquilamento das regras de propriedade ou mesmo pela garantia imediata de status de cidadão aos ocupantes, todos atribuem ao texto constitucional uma força normativa imperiosa, capaz de gerar uma desordem urbana no sentido de estremecer a lógica de proteção e manutenção dos privilégios até então (e até hoje) vigentes. Tais recortes coadunam, neste sentido, com um sentimento generalizado à época de grande crédito às normas constitucionais e seu potencial transformador da realidade.

As transformações nas cidades brasileiras, entretanto, foram inegavelmente mais tímidas do que o esperado. À época, parte dessa timidez foi justificada pela falta de auto-aplicabilidade de muitos dos dispositivos constitucionais. Ainda assim, a experiência constituinte foi positivamente avaliada pelo MNRU como um "processo de conquista da nova Constituição Brasileira" (MARICATO, 2014, p. 145) e "um grandioso espaço de luta política, em que as forças populares tiveram um árduo trabalho, articularam suas demandas e ao mesmo tempo fizeram o embate com poderosos lobbies das forças conservadoras" (SAULE JUNIOR e UZZO, 2010, p. 260). Nos anos seguintes à promulgação da Constituição Federal, a estratégia da elaboração de direitos urbanos continuou a ser perseguida pelo MNRU.

Entretanto, ao longo dos anos, tal estratégia foi sofrendo transformações, passando a focar muito mais na demanda pela elaboração de legislações e na atuação institucional do MNRU, ao mesmo tempo que assentava um ideal de Reforma Urbana não 
mais calcado no direito advindo do conflito ou da experiência, mas no direito resultado de pactos e acordos entre diferentes forças sociais, mediadas pelo Estado.

\section{Dos direitos ao Direito ou os rumos do campo jurídico-institucional}

A avaliação positiva do processo constituinte e a necessidade de aprovação de normas regulamentadoras dos artigos constitucionais da Política Urbana impulsionaram, no âmbito das lutas urbanas, a agenda de elaboração de direitos na esfera infraconstitucional. Finalizado o processo constituinte, o Fórum Nacional pela Reforma Urbana (FNRU) foi criado "com o objetivo imediato de pressionar o Congresso Nacional para regulamentar o Capítulo da política urbana, da Constituição Federal de 1988" (SAULE JUNIOR e UZZO, 2010, p. 263). Seus esforços voltaram-se, neste sentido, para a formulação e negociação institucionalizada de propostas para uma Lei Federal de Desenvolvimento Urbano que regulamentasse as normas do referido capítulo e também para a criação de fóruns de participação a níveis estadual e municipal voltados às disputas das Constituições Estaduais, das Leis Orgânicas Municipais e dos Planos Diretores. A ideia era, a partir dessas disputas, avançar em algumas propostas que tinham ficado de fora do texto constitucional final (TANAKA, 2017; CARDOSO, 1997).

No âmbito local, as Leis Orgânicas dos Municípios começaram a ser formuladas nos primeiros anos após a promulgação da Constituição, visto que o seu artigo 29 instituiu, de maneira inédita, a exclusividade de competência ao Poder Municipal de promulgar sua respectiva Lei Orgânica. Neste sentido, entende-se que a Constituição Federal, pela primeira vez, reconheceu a capacidade de organização autônoma dos Municípios e atribui-lhes novas funções e competências, de maneira a abrir um novo campo de possibilidades no que tange à regulamentação do urbano em sede local (FERNANDES, 2010).

Os movimentos sociais de caráter local, muitos dos quais ligados ao FNRU, colocaram-se ativos nesse processo de formulação da Constituição Municipal. Destacam-se, em São Paulo, uma campanha realizada pela União dos Movimentos de Moradia (UMM), que tinha como base a cartilha 'A cidade faz a sua Constituição', a qual reforçava a importância da atuação popular nos espaços de produção legislativa como 
forma de obtenção de conquistas e avanços na luta e que foi usada como material para uma expressiva campanha de mobilização dos setores populares no processo legislativo. (SAULE JUNIOR e SILVA, 1993)

Tais processos foram também vistos com entusiasmo na época, pois teriam conseguido elaborar seus princípios constitucionais avançando ainda mais nos direitos já positivados na Constituição Federal. (SAULE JUNIOR e SILVA, 1993, p. 09).

Vale ressaltar, também, que o período de elaboração legislativa municipal, não raro, coincidiu com o período das "gestões democráticas e populares" (MARICATO, 2014, 2015), que foram constituídas a partir da possibilidade de, nos municípios, serem realizadas eleições diretas e disputas livres aos cargos majoritários desde 1985 (MARICATO, 2014). Assim é que gestões progressistas, no geral levadas à cabo pelo PT, assumiram o comando de importantes cidades como São Paulo, Diadema e Santo André (MARICATO, 2014) e cujos técnicos, em geral alinhados aos ideais da Reforma Urbana, passaram a compor as instâncias institucionais do poder local. Havia, neste sentido, uma abertura e iniciativa inédita por parte dos gestores locais às demandas da Reforma Urbana e dos movimentos sociais urbanos, muitos deles ligados ao FNRU. Tais movimentos perceberam tal abertura e, progressivamente, passaram a enfatizar os processos de elaboração legislativa e negociação institucional nas suas agendas de lutas locais.

Neste contexto, foram introduzidos avanços importantes em termos de debate, criação e efetivação, em âmbito local, de novos programas e novas formas de gerir a cidade (MARICATO, 2014). Avanços como os orçamentos participativos, o impulso à urbanização de favelas, a promoção de políticas voltadas à cidade marginal - ou seja, as políticas de 'inversão de prioridades' (MARICATO, 2014) - foram marcas dessas gestões, configuradas como o 'novo urbanismo democrático-popular':

"O novo urbanismo democrático-popular promove inversões de prioridades, projetos e obras de urbanização de favelas - no lugar da remoção forçada, que era a prática comum anterior -, a regularização fundiária, a construção de praças, escolas, saneamento e drenagem urbana, a produção de moradias por mutirão e autogestão, com qualidade superior às construtoras, 
políticas de assistência social de novo tipo, com experiências de economia solidária, além dos orçamentos participativos, que caracterizavam 'o modo petista de governar'. Iniciativas que foram naquele momento importantes referências da transformação social" (ARANTES, 2013, s/pg.)

No âmbito federal, destaca-se a grande mobilização pelo Fundo Nacional de Moradia Popular (FNMP) durante o ano de 1991, levada a cabo principalmente pela UMM, de maneira desvinculada do FNRU, e que culminou no primeiro Projeto de Lei de Iniciativa Popular (o PL ${ }^{\circ}$ 2.710/1992), subscrito por mais de 1 milhão de pessoas (TANAKA, 2017; PAZ, 1996). No âmbito do FNRU, a luta pela Reforma Urbana foi travada, especialmente, por meio de negociações, barganhas e disputas ideológicas e jurídicas (FERNANDES, 2010), em prol da aprovação do Projeto de Lei $\mathrm{n}^{0} 5.788 / 1990$, que regulamentava os artigos constitucionais da política urbana - o qual, após mais de uma década, foi aprovado nos termos da Lei Federal $n^{\circ}$ 10.257/2001, mais conhecida como Estatuto da Cidade. Foi uma luta árdua do FNRU e dos outros movimentos sociais como a União Nacional dos Movimentos Populares (UNMP), e que culminou num resultado aparentemente grandioso: a aprovação do Estatuto da Cidade, considerada o coroamento de uma nova ordem jurídico-urbanístico nacional e elevação do direito às cidades sustentáveis como direito fundamental da pessoa humana (FERNANDES e ALFONSIN, 2010).

Assim, se antes era possível frear o avanço democrático nas cidades brasileiras sob a justificativa da necessidade de regulamentação dos dispositivos constitucionais, com a aprovação do Estatuto da Cidade consolidou-se um "suporte jurídico consistente e inequívoco à ação dos governos e da sociedade organizada para controle dos processos de uso, ocupação, parcelamento e desenvolvimento urbano" e o apoio institucional aos "governos municipais que se têm empenhado no enfrentamento das graves questões urbanas, sociais e ambientais que afetam diretamente a vida da enorme parcela de brasileiros que vivem em cidades." (FERNANDES, 2010, p. 55). A questão urbana foi finalmente afirmada nos termos de uma política institucionalizada munida de princípios e diretrizes, instrumentos jurídicos-urbanísticos, procedimentos e regramentos para a elaboração dos Planos Diretores Municipais, conceitos, competências e, aos olhos mais otimistas, consolidou uma "nova concepção - proposta pela Constituição Federal (...) - 
dada ao direito de propriedade imobiliária urbana, qual seja, o princípio constitucional das funções sociais da propriedade e da cidade" (FERNANDES, 2010, p. 56).

De fato, um dos principais pontos assinalados como conquistas da promulgação do Estatuto da Cidade foi a consagração da função social da propriedade urbana como medida de restrição ao direito de propriedade, que até então era entendido como um direito absoluto, "'natural', intocável, quase sagrado, sem maior preocupação com outros interesses sociais e ambientais na utilização do solo urbano (FERNANDES, 2010, p. 57). Se a Constituição Federal já submetia o direito de propriedade ao cumprimento de sua função social, com a regulamentação prevista no Estatuto da Cidade, tal submissão tornou-se menos retórica e mais concreta - ainda que instrumentos importantes como o Parcelamento, Uso e Edificação Compulsórios ainda dependessem de regulamentação municipal específica. A sensação, especialmente entre os juristas progressistas e alinhados à bandeira da Reforma Urbana, era de que a função social da propriedade, agora regulamentada pelo Estatuto da Cidade, representaria uma transformação significativa do princípio da propriedade privada, um dos pilares do direito moderno:

"A verdade é que muito se avançou, desde que as possibilidades de ação do estado em particular, e do poder público em geral, no controle da propriedade imobiliária e do desenvolvimento urbano eram limitadas ao binômio civilista 'usucapião/desapropriação'. Do Código Civil de 1916 ao Estatuto da Cidade em 2001, isto é, do princípio da propriedade individual irrestrita ao princípio das restrições urbanísticas ao direito de propriedade, até chegar ao princípio atual das funções sociais da propriedade e da cidade, a ordem jurídica de controle do desenvolvimento urbano já foi totalmente reformada no Brasil. Da mesma maneira, as bases da gestão democrática da cidade foram claramente colocadas pela Constituição Federal de 1988 e reafirmadas pelo Estatuto da Cidade." (FERNANDES e ALFONSIN, 2010, p. 15 - grifos nossos)

Mesmo aos olhos não tão otimistas - que, no geral, davam ênfase ao longo caminho a ser trilhado para a efetivação do Estatuto da Cidade e avaliavam que os mais de 
10 anos de vigência da Constituição Federal não tinham refletido uma melhora significativa das condições de cidadania e de justiça urbana -, era difícil não reconhecer os avanços institucionais garantidos pela aprovação da referida lei. A política urbana estava institucionalizada a nível federal e o direito à moradia e às cidades sustentáveis configuravam como direitos fundamentais de todos os cidadãos; a nível municipal, estavam estabelecidas as competências para a regulação do solo urbano e as Leis Orgânicas instituíam instrumentos de participação e gestão popular nas cidades. Parecia não restar dúvida quanto à presença, no cenário jurídico brasileiro, de um ordenamento jurídico e uma estrutura institucional que pudessem apontar para a realização da justiça social nas cidades brasileiras. E, com a ascensão do Partido dos Trabalhadores ao Governo Federal, as condições para a democratização das cidades pareciam dadas. Contraditoriamente, não foram ventos democráticos que sopraram nas cidades brasileiras durante os últimos 14 anos.

O entusiasmo, especialmente dos setores de esquerda mais alinhados ao campo democrático-popular, em relação à eleição de Luiz Inácio Lula da Silva, em 2003, era visível. No âmbito da Reforma Urbana, a eleição representava "uma inflexão progressista na coalização de partidos que governam o país e a adoção de uma nova agenda reformista, incorporando as propostas elaboradas pelos pensadores e pelas organizações vinculadas ao movimento da reforma urbana" (SANTOS JUNIOR, 2009, p. 11). Uma das propostas incorporadas foi a criação do Ministério das Cidades - uma reivindicação que constava da primeira proposta de Reforma Urbana debatida em 1963 e que havia sido retomada no período mais recente - que "expressou o reconhecimento, pelo governo federal, da questão urbana como uma questão nacional a ser enfrentada por macropolíticas públicas" (SANTOS JUNIOR, 2007, p. 296).

A expectativa geral era de que, consolidada uma nova ordem jurídico-urbanístico nacional e criado o Ministério das Cidades, seria possível ampliar para a escala nacional, a partir de uma agenda de política urbana, os avanços conseguidos em escala local durante as gestões democrático-populares: 
"Quando Lula foi eleito, criamos o Ministério das Cidades, o Conselho Nacional das Cidades, a Conferência Nacional das Cidades e parecia que, finalmente, poderíamos passar de uma escala local a uma política urbana de abrangência nacional." (MARICATO, 2015, p. 104)

Houve, assim, um deslocamento de diversos técnicos, pesquisadores e profissionais ligados à Reforma Urbana para os gabinetes do Governo Federal, para compor cargos políticos de planejamento e efetivação de tal política, ao mesmo tempo que os movimentos sociais ligados à Reforma Urbana se deslocaram também aos espaços institucionais de participação popular que foram reiteradamente criados ao longo da década de 2000.

Entretanto, o que observamos é que, na esfera federal, não foram traduzidas as inovações trazidas pelas experiências municipais. Se, em tais esferas, os espaços de participação popular e os processos de gestão permitiam uma disputa de hegemonia e poderiam representar uma ampliação do espaço dos movimentos em direção a um "socialismo democrático", na esfera federal, os sentido dos espaços e disputas institucionais foi muito diferente (MARTINS, 2012).

Ao longo dos anos, tais movimentos, seguindo a hegemonia do 'participativismo' tão em voga nas agendas internacionais (MARICATO, 2011), passaram a limitar suas ações, atraídos pelos espaços institucionais ou pela institucionalização de práticas participativas. Ao se voltarem para tais espaços, acabavam por incorporar discursos, práticas e prioridades ligadas às agendas oficiais do Estado. Assim começa a ser construído, nas lutas pela Reforma Urbana, um ideal de "prática 'responsável' de quem propõe novos instrumentos legais, participa de conselhos de fundos públicos e seus programas governamentais, tudo dentro da ordem (o ciclo institucional)." (ARANTES, 2013, s/pg). Os movimentos sociais ligados ao MNRU, neste sentido, passaram a dar um peso muito forte às iniciativas de participação no jogo político institucional, priorizando uma postura de 'diálogo', de negociação, de respeito às regras impostas e aos limites do Estado, em detrimento de processos mais ofensivos de lutas.

Assim, os rumos das lutas pela Reforma Urbana se direcionam neste sentido, afastando-se do "confronto político, de autonomia, de independência política e utopia 
social" e incorporando "um discurso genérico do direito à cidade, que deverá ser alcançado por meio do aperfeiçoamento legal, institucional e da ampliação da participação popular" (MARICATO, 2014, p. 153). Neste sentido, as práticas de luta pela Reforma Urbana centraram suas energias na composição de um cenário jurídico-institucional vigoroso, em que os sentidos de realização da Reforma Urbana dependiam de uma regulamentação densa.

"Acima de tudo, a experiência brasileira tem claramente demonstrado que a reforma urbana requer uma combinação precisa, ainda que quase sempre elusiva, entre mobilização social renovada, reforma jurídica e mudança institucional." (FERNANDES, 2010, p. 70 - grifos nossos)

Nesta linha de raciocínio, a Constituição Federal precisava ser regulamentada, assim como também era preciso regulamentar o Estatuto da Cidade por meio dos Planos Diretores Municipais; entretanto, somente a consolidação das normas jurídicas nos respectivos entes federativos não bastava, pois sua aplicação dependia especialmente das políticas a nível municipal e dos entendimentos dos tribunais; mas, devido à escala das questões urbanas, era preciso expandir, também, a escala de suas políticas, devendo ser incorporados os Estados e a União; entretanto, o poder público era apenas um dos atores envolvidos na questão urbana, de maneira que outros atores precisavam ser envolvidos...

"A aprovação do Estatuto da Cidade inegavelmente consolidou a ordem constitucional no Brasil (...). Sua efetiva materialização em políticas e programas vai, sobretudo, depender da reforma das ordens jurídico-urbanísticas locais. Ou seja, do quadro regulatório e institucional que for criado por cada município para o controle do uso e desenvolvimento do solo, particularmente pela aprovação de planos diretores adequados e dos processos locais de gestão urbana. O papel dos municípios é crucial para reverter o padrão excludente de desenvolvimento urbano no Brasil. Mas, a escala da questão urbana no Brasil é tamanha, e tão grande é a urgência de 
enfrentá-la devido a todas suas implicações jurídicas, sociais, ambientais, financeiras etc., que não se pode mais falar apenas em políticas municipais: ampla articulação intergovernamental se faz necessária, especialmente pelo envolvimento dos Estados, que até agora na sua maioria não formularam uma política urbana e habitacional clara (inclusive no que diz respeito às terras devolutas e outras terras estaduais), e da União, gerando um contexto de políticas nacionais. Além disso, a promoção de reforma urbana no Brasil requer políticas públicas que envolvam o setor comunitário, o setor voluntário, a academia e o setor privado." (FERNANDES, 2010, p. 68)

O caminho apontado acima pelo jurista Edésio Fernandes parece infindável; cada etapa jurídica e institucional aponta para outra, e esta para outra, até supostamente chegar no patamar em que o Estado esteja blindando contra as arbitrariedades do mercado e, ao mesmo tempo, munido de competências e responsabilidades no cumprimento dos direitos urbanos e políticas públicas que visassem à realização das condições de justiça da Reforma Urbana.

Neste sentido, a medida de realização da justiça urbana foi sendo colocada em um horizonte cujo caminho a ser percorrido era uma série de etapas jurídico-institucionais. E este parece ter sido exatamente o caminho trilhado pela Reforma Urbana - exceto pelo fato de que, etapa após etapa, ação após ação, não se atingiu o horizonte pretendido. Restou-nos um vistoso arcabouço institucional e jurídico relacionado aos temas da Reforma Urbana, como pode ser observado na sistematização a seguir: 
- Linha do tempo -

pagina vazia 
Vale ressaltar que tais legislações, políticas e espaços institucionais foram comemoradas enquanto vitórias ou conquistas da Reforma Urbana (MARICATO, 2010; FERNANDES, 2010; SAULE JUNIOR e UZZO, 2011; FERNANDES e ALFONSIN, 2010), ainda que muitas delas também tenham regulamentado instrumentos prioritariamente voltados aos mercados, como as Operações Urbanas Consorciadas e as Parcerias Público-Privadas. Assim, a transição das lutas urbanas no Brasil pelos movimentos sociais ligados ao MNRU para a elaboração de lutas na esfera institucional parece atingir seu ponto alto a partir da década de 2000.

Os sentidos da justiça social, que nos anos anteriores vinham da garantia dos direitos urbanos enquantos direitos de cidadania e forjados a partir da síntese das experiências dos movimentos sociais, foram se perdendo, diluindo-se em um vasto arcabouço legal e em um sem-número de espaços participativos que (quando muito) debatiam aquilo que seria efetivamente decidido nos gabinetes.

Ao longo dos anos 2000, a agenda da Reforma Urbana foi distanciando-se das lutas urbanas massivas e caminhando em direção a uma "guinada conservadora" (MARICATO, 2014; TANAKA, 2017). Tal guinada parecia fruto não só da escolha consciente pelo campo jurídico-institucional em si, mas também pela forma que tal campo era acessado. Seguindo a toada das gestões petistas no Governo Federal, uma parte considerável dos ideólogos da Reforma Urbana defendiam a necessidade de uma atuação institucional estratégica que visasse à consolidação de pactos entre os diferentes setores da sociedade interessados nas questões urbanas, para assim conseguir avançar na pauta da Reforma Urbana de maneira menos conflituosa possível (TANAKA, 2017):

"Mesmo em um quadro jurídico hostil, é possível promover avanços jurídico-urbanísticos importantes, desde que exista um sólido pacto sociopolítico que dê suporte à ação do poder público. O Estatuto da Cidade consolidou um paradigma jurídico no qual existe um direito difuso à cidade, ao ordenamento territorial, ao planejamento urbano e à gestão democrática da política urbana, todos direitos da coletividade aos quais corresponde a obrigação do poder público de promover uma política urbana que garanta as funções sociais da cidade e da propriedade. Não se trata mais tão 
somente de uma questão da alçada do poder discricionário do Poder Público, que faz o que quer, quando e como quiser. Da mesma forma, os proprietários de imóveis urbanos passaram a se submeter a um conceito de cidade na qual, mais do que nunca, o seu direito individual de propriedade não pode ser considerado absoluto, já que deve observar as regras de ordenação da cidade expressas pelo plano diretor. Resta criar um sólido pacto sociopolítico para garantir sua efetividade." (FERNANDES, 2010, p. 69 - grifos nossos)

"As bases estavam lançadas: o projeto democrático-popular propunha uma aliança de classes por uma Reforma Urbana sem conflitos e com "mercado para todos". (ARANTES, 2013, s/pg)

À crítica dos limites transformadores das legislações na sociedade brasileira, sobrevinham a necessidade de criação de consensos mediados pelo Estado que garantisse um "lugar para todos, e necessidade de todos" (FERNANDES, 2010, p. 59), e o Programa Minha Casa Minha Vida, nos moldes da Lei Federal 11.977/2009, parece ser um exemplo simbólico destes pactos. A política de conciliação de classes da era Lula, descrita por André Singer em "Os Sentidos do Lulismo", se reflete claramente nos rumos da luta pela Reforma Urbana ao, mediante pactos entre os diferentes atores interessados na produção das cidades, todos pareciam ganhar alguma coisa, por mais simbólica que tal vitória pudesse ser. Neste sentido, dezenas de legislações foram aprovadas sem que nenhuma tocasse em pontos fundamentais da estrutura urbana brasileira, como a necessidade de enfrentamento à concentração fundiária ou à limitação dos valores impostos no mercado de aluguéis. Era como se a 'caixa' de direitos urbanos fosse constantemente preenchida muitas vezes, inclusive, de acordo com as demandas do MNRU e demais movimentos que protagonizaram este momento político -, ao mesmo tempo que a 'caixa' dos deveres dos proprietários de terras, dos representantes do capital financeiro e imobiliário e outros grandes agentes do mercado permaneceu intacta. A sensação de avanços, neste sentido, era clara, porém ilusória, na medida em que as condições estruturantes da desigualdade das cidades, e mesmo da sociedade brasileira, permaneciam incólumes. Leva-se energia 
elétrica às regiões mais pobres do sertão nordestino, mas não negocia as tarifas abusivas cobradas pelas agências especiais; amplia-se o acesso à internet, mas não regulamenta a cobrança das operadoras; fala-se de moradia popular, mas a saída favorece intensamente as grandes construtoras.

As condições das cidades brasileiras parecem se transformar, mas sua essência revela uma sensível piora das condições de reprodução da classe trabalhadora (MARICATO, 2014; ARANTES, 2013). Com a política de pactos e conciliação de classes, a bandeira de luta da Reforma Urbana acaba perdendo de vista a centralidade da terra urbana para a realização da justiça social (MARICATO, 2015).

É preciso ressaltar, no entanto, que à medida que tal processo foi se desenvolvendo, também foram sendo feitos debates e avaliações sobre os limites estratégicos do campo jurídico-institucional nas lutas pela Reforma Urbana. Mesmo assim, parece que pouco foi reavaliado pelo MNRU e demais movimentos sociais que protagonizaram a luta por tal agenda e o processo que culminou na perda de ofensividade destes movimentos e mesmo da agenda da Reforma Urbana continuou se desenrolando nos anos seguintes. Os quatro movimentos nacionais de moradia mais emblemáticos à época - a UMM, CMP, MNLM e CONAM - foram sendo engolidos pelos espaços institucionais e suas lideranças, incorporadas aos gabinetes.

Assim, se é verdade que os movimentos ligados à Reforma Urbana "ganharam adeptos em diversos setores da sociedade, construíram uma leitura original sobre a cidade periférica, dando visibilidade ao que era invisível, e uma agenda original sobre a reforma urbana (MARICATO, 2011, p. 55), também é possível dizer que tais movimentos "'bateram no teto', isto é, estão fragmentados e muito desmobilizados e tem poucas possibilidades de avanço real na linha preconizada pelas agendas tão debatidas em um sem número de encontros, reuniões, congressos, seminários, etc." (MARICATO, 2011, p. 38).

Em 2013, entretanto, tal situação sofreu um grande abalo. As cidades brasileiras, que sofreram diretamente os efeitos colaterais do crescimento econômico a todo custo e se viram em uma situação de "inviabilidade crônica" (ARANTES, 2013, s/pg), foram transformadas em palcos de grandes protestos e manifestações populares impulsionadas pelas reivindicações lideradas pelo Movimento Passe Livre (MPL) em face da precariedade e do alto custo dos transportes públicos urbanos. Tais manifestações, no geral compostas 
por jovens politizados mas não partidarizados, ganharam as ruas das principais capitais brasileiras, romperam com a letargia que vinha recaindo sobre os principais movimentos sociais e reposicionaram os sentidos da luta urbana novamente às ruas. 


\title{
capítulo 2. 2013 e as novas emergências políticas
}

\section{As rupturas das Jornadas de Junho de 2013}

\author{
"Devemos apostar na rebelião do desejo. \\ Aqueles que se apegarem às velhas \\ formas serão enterrados com elas." (IASI, \\ 2013, s/p.)
}

Ao longo dos primeiros anos da década de 2010, o cenário das lutas urbanas parecia pouco animador. Ainda que na esfera federal houvesse a institucionalização de um Ministério, repleto de técnicos, pesquisadores e militantes alinhados aos ideais da Reforma Urbana, que finalmente pareciam ter o domínio da máquina pública federal para instituir políticas que visassem à efetivação dos referidos ideais; ainda que no âmbito jurídico tivessem sido aprovados diversos marcos legislativos referentes aos aspectos mais importantes da questão urbana, como o saneamento, regularização fundiária, programas habitacionais e mobilidade urbana; ainda que no âmbito institucional tivessem sido multiplicadas as instâncias de participação popular, conselhos, conferências, muitas delas para discutir os rumos da política urbana e dos programas governamentais; ainda que, no âmbito dos municípios, os Planos Diretores tivessem sido alvos de campanhas nacionais, processos participativos, debates e que muitos tivessem recepcionado os princípios e instrumentos jurídico-urbanísticos instituídos pelo Estatuto da Cidade; ainda diante de tudo isso, a democratização das cidades defendida pela 
Reforma Urbana parecia cada vez mais inatingível e, ainda pior, as condições de vida nas cidades brasileiras pareciam se deteriorar (MARICATO, 2015; ARANTES, 2013). Os avanços pareciam não só insuficientes mas promovedores do que Arantes (2013) chamou de uma Anti-Reforma:

"O Programa Democrático-Popular e seu capítulo da Reforma Urbana não apenas não realizou o que prometeu, mas deu no seu contrário, numa Anti-Reforma, ou numa privatização/ mercantilização crescente das cidades, tratadas como mais um ramo dos negócios. A face social da Reforma Urbana democrático-popular foi sendo recalcada a favor de soluções de mercado, das parcerias público-privadas e da gestão localizada da pobreza." (ARANTES, 2013, s/pg)

É preciso, entretanto, ressaltar que a precarização da vida urbana foi (e tem sido) fruto também de processos mais amplos da conjuntura global de acumulação capitalista, da crescente financeirização do espaço urbano e dos retrocessos econômicos e sociais de uma década de neoliberalismo. De fato, a piora das condições de vida urbana é um processo mundial como apontado por inúmeros estudiosos, dentre eles Davis (2006). Isso não quer dizer, por outro lado, que os efeitos da nova dinâmica de acumulação capitalista que afetam diretamente as cidades não pudessem ser controlados, geridos e diminuídos por meio de políticas públicas e investimentos estatais ou mesmo denunciados e combatidos pelos movimentos ligados à Reforma Urbana.

Entretanto, nenhum dos caminhos parecia ser priorizado até então: ao mesmo tempo em que os movimentos pela Reforma Urbana, como vimos no capítulo anterior, desenhavam uma atuação voltada à formulação de pactos e acordos, ainda que às custas de ampliação de benefícios ao mercado, o Estado privilegiava no seu programa econômico políticas voltadas ao aquecimento do mercado interno, à distribuição de renda e à valorização salarial que, apesar de promoverem uma melhoria qualitativa na condição de vida da classe média e dos setores populares, não eram suficientes para melhorar as condições de vida urbana gerais, as quais só poderiam ser efetivadas por meio do investimento em políticas públicas: 
"(...) ou se remunera os capitais (...) ou se investe na reprodução do trabalhador: saúde, educação, transporte, moradia, saneamento... (...) o problema não se resolve com a distribuição de renda ou do salário. Porque mais salário não compra o transporte coletivo; não compra uma boa localização na cidade, porque isso fica mais caro. Aumento salarial é absorvido pelo custo da cidade e isso só se resolve com políticas públicas." (MARICATO, 2015, p. 108)

Neste cenário, as condições da vida urbana pioraram de maneira a constituir uma causa explicativa fundamental - mas não a única - para a explosão das Jornadas de Junho de 2013 (MARICATO, 2015).

Tais jornadas, desencadeadas a partir da luta organizada pelo MPL-SP a partir da luta pela revogação do aumento das passagens do transporte público, levaram milhares de pessoas às ruas em todo o Brasil. E, embora seus efeitos sejam ainda hoje objeto de intensos debates, parece possível dizer que tais Jornadas representaram um momento político essencialmente de ruptura: seja com a "tremenda fábrica de consentimento" até então vigente no cenário político nacional (para usarmos uma expressão de Paulo Arantes); com a ideia recorrentemente vendida de que o país vivia um processo de ascenso contínuo e exponencial - ou nas palavras de Arantes (2013), num "cenário cor-de-rosa do Brasil emergente"; seja com as estratégias e movimentos sociais que até então protagonizavam a cena política e que pareciam não ter mais capacidade de representar politicamente os novos sujeitos sociais.

Tais sujeitos - denominados 'novíssimos' movimentos sociais por Maricato (2015), em alusão à obra de Eder Sader (1988) - ascendem na cena política de maneira surpreendente por serem abertamente críticos à política institucional (quando não a negavam absolutamente) e por direcionarem as lutas às ruas ao entendê-las como locais privilegiados de luta social. Assim, partir das ações de tais sujeitos, as ruas foram retomadas como espaço político fundamental da luta de classes e de manifestação política. Durante apenas o mês de junho de 2013, milhões de brasileiros foram às ruas contra o aumento do valor das passagens de ônibus e a favor de novas políticas de mobilidade urbana. As manifestações, apoiadas por uma maioria expressiva da 
população, foram violentamente reprimidas pela Polícia Militar e Civil e foram alvo de ataques em intensas campanhas midiáticas; mesmo assim, em menos de 20 dias, 14 capitais e diversas cidades brasileiras anunciaram a redução das passagens (MANIFESTAÇÕES..., 2013) - assim como posteriormente foi anunciado por quase mais 100 cidades - e, só em São Paulo, uma amplamente criticada licitação dos transportes públicos foi suspensa, as obras dos corredores de ônibus foram prontamente retomadas e uma CPI dos Transportes Públicos foi instituída na Câmara Municipal, para citar somente algumas das conquistas obtidas (MARICATO, 2015).

Tais conquistas se tornaram símbolo de um novo horizonte político que indicava que as ruas, quando ocupadas pelo povo organizado e massificado, poderiam angariar vitórias que à primeira vista pareciam impensáveis (BOULOS, 2015b). Mesmo a questão da revogação do aumento das passagens de transporte público, havia anos que estava sendo reivindicada pelo MPL em atos de ruas; porém, as condições sociais e políticas do contexto de 2013 permitiram que ao movimento fosse possível mobilizar milhares de pessoas e, a partir da questão da mobilidade, retomar a questão urbana no âmbito da agenda política nacional (MARICATO, 2015). Ao propor novas formas de atuação nas lutas urbanas, negava-se os rumos das lutas pela Reforma Urbana que haviam sido reiterados durante principalmente os últimos anos - caracterizado por um jogo velado no qual os movimentos sociais reivindicavam de maneira "responsável", dentro dos limites institucionais e políticos aceitos pelo Governo Federal (ARANTES, 2013), enquanto este concedia pequenas brechas em forma de legislações e políticas públicas que, sem impactar a política de conciliação de classes, não chegavam nem perto das questões fundiárias (MARICATO, 2014).

O MPL, em suas manifestações em São Paulo, fez uma aposta consciente pelas ruas ao não incluir o agendamento de reuniões com os órgãos municipais e estaduais competentes no seu rol de reivindicações; para o movimento, valia mais estimular os processos de mobilização e de resistência social e, a partir delas, ocupar os espaços públicos e tensioná-los até que não fosse mais possível ao Poder Público ignorar suas pautas, do que propriamente garantir suas reivindicações a partir dos seus contatos e representantes em altos cargos do Estado. Também foi uma aposta consciente que o movimento fez pelo enfrentamento à Polícia - que não só evidenciou o caráter de classe e raça dos participantes do movimento (que puderam escolher entrar em confronto com a 
Polícia) mas também que gerou uma comoção nacional fortíssima a seu favor (MARICATO, 2015). O horizonte político que destacava que o povo organizado na rua poderia exercer um poder político transformador parecia, de fato, perseguido e disseminado por meio das lutas do MPL.

Tal horizonte político implicou em diversos desdobramentos, entre os quais destacamos seus efeitos nas periferias urbanas, ainda que seus moradores não tenham participado diretamente das manifestações das Jornadas de Junho. Assim, nas semanas subsequentes à primeira onda de protestos de 2013, as periferias aceleram sua dinâmica política. Um exemplo disso foram as quase 700 ocupações espontâneas realizadas nos meses de julho e agosto nas periferias de São Paulo - algo em torno do triplo da quantidade de ocupações registradas nos períodos anteriores correspondentes (BOULOS, 2015b). E, se tais ocupações são reflexos de importante iniciativas a classe trabalhadora, não podemos deixar de pontuar que elas também podem implicar no aumento da precariedade das condições de vida de tal classe, que ao ocupar terrenos sem infraestrutura prévia, ficam à mercê da sua própria força de trabalho para minimamente garantir condições adequadas de sobrevivência. Assim, acompanhado dos processos de ocupação espontânea, também emerge um movimento de demanda da classe trabalhadora por um direcionamento e organização política das suas iniciativas, para que elas possam implicar em avanços positivos na sua qualidade de vida. Neste sentido, ao mesmo tempo que as manifestações de 2013 garantiram "instigar um conjunto de reivindicações populares", dentre as quais se insere a pauta da moradia e da Reforma Urbana, também "propiciou aos movimentos uma base de apoio ativa para ampliar a luta com novas e contundentes ações" (BOULOS, 2015a, pp. 19 e 20).

Nos meses subsequentes, apesar dos diversos desencadeamentos das Jornadas de Junho, a questão urbana continuo no centro das lutas populares. No início de 2014, por exemplo, houve 185 manifestações no período de 114 dias, como mostra o levantamento realizado pela Polícia Militar do Estado de São Paulo a pedido do jornal O Estado de São Paulo (MORADIA LEVA..., 2014) e, dentre elas, apontamos uma forte presença de manifestações voltadas à questão urbana. Na notícia que apresentava tal levantamento, era destacada a ocorrência de manifestações pela moradia, que aparecia como a pauta mais mobilizadora das manifestações ocorridas no período, com exceção da histórica pauta trabalhista que, disparada em primeiro lugar, contou com 43 manifestações. 
Isso por si só já é um dado relevante da realidade daquele contexto, visto que, nos últimos anos, a luta pela moradia parecia estar mais sendo reivindicada nos gabinetes do que propriamente nas ruas. Entretanto - e apesar da dificuldade de analisar os dados apresentados, visto que não é possível saber os critérios utilizados na setorização das manifestações - se somarmos a quantidade de manifestações cujas pautas dialogam diretamente com reivindicações históricas da Reforma Urbana, como moradia, transportes e segurança pública e mesmo com outras correlatas, como as reivindicações contra a Copa do Mundo, percebemos que elas perfazem a maioria das manifestações ocorridas no período, sobrepondo quantitativamente, inclusive, o número de manifestações voltadas às reivindicações dos direitos trabalhistas.

Sistematização do levantamento das manifestações realizadas de 1 de janeiro a 24 de abril de 2014.

Fonte: O Estado de São Paulo, 07/05/2014 ${ }^{13}$

Neste sentido, as Jornadas de Junho de 2013 inauguram um processo político que colocava a questão urbana novamente no centro da disputa política popular, abria espaço para a emergência de novos movimentos e sujeitos políticos e colocava na ordem do dia a necessidade de reavaliação das estratégias e práticas das lutas urbanas. Neste processo, novos movimentos que, no cenário das

${ }^{13}<\underline{\text { http://sao-paulo.estadao.com.br/noticias/geral,moradia-leva-mai }}$ Acesso em 26/08/2017.

\section{NAS RUAS}

- Levantamento foi feito pela Polícia Militar entre 10 de janeiro e 24 de abril

\section{Manifestações, por tema}
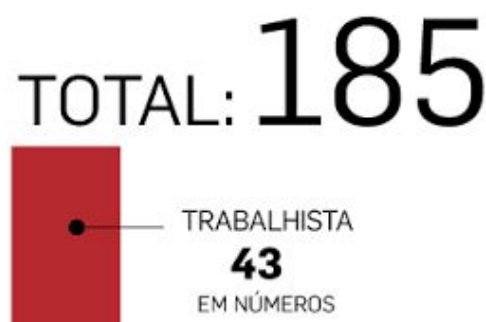

EM NÚMEROS

MORADIA

23

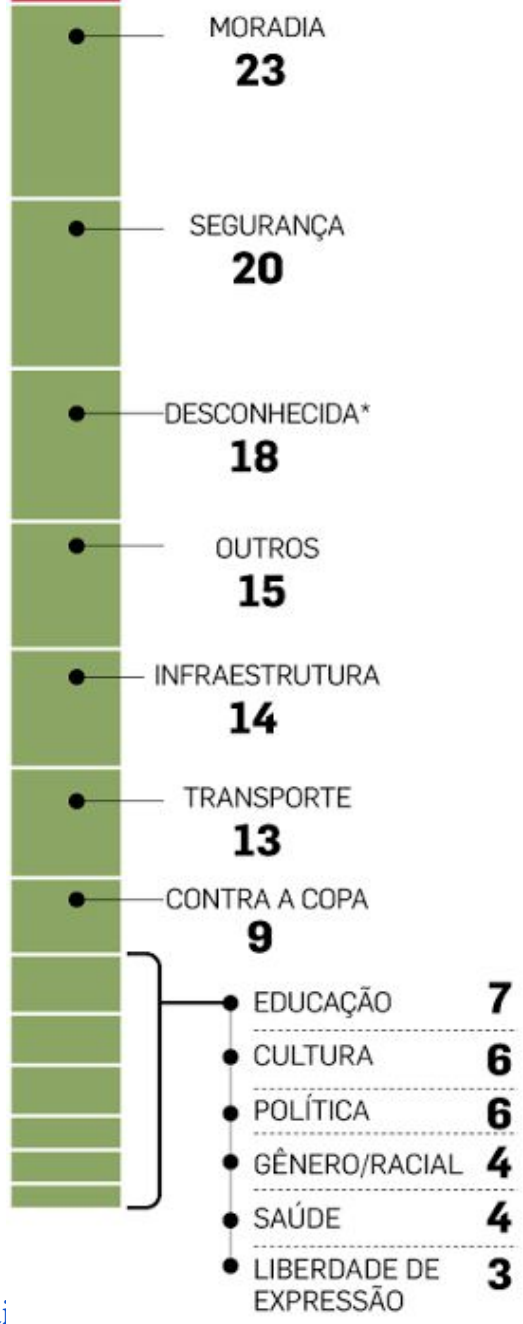


lutas urbanas, reivindicavam especificamente a bandeira de luta da Reforma Urbana surgiram e/ou se reposicionaram na cena política (MARICATO, 2015); vejamos, no próximo capítulo, como o MTST se reposicionou politicamente neste processo e como sua leitura de realidade e concepções políticas, diante da conjuntura atual, direcionam suas práticas para outros usos e pesos do Direito.

\section{FOLHA DE S.PAULO}

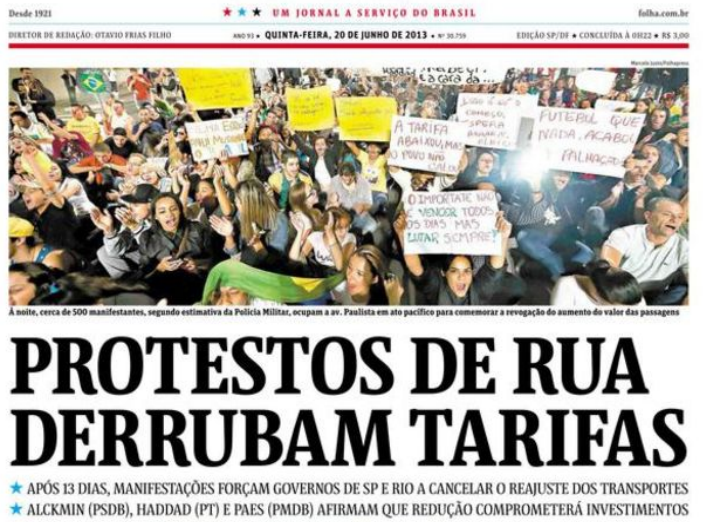

Fonte: Folha de São Paulo, 20/06/2013

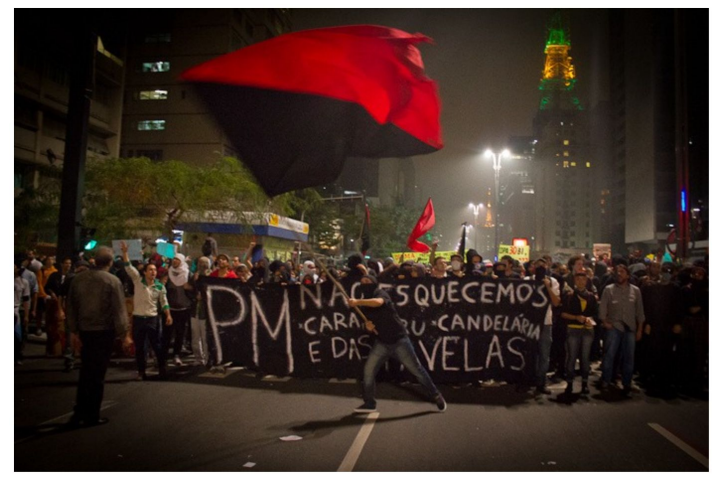

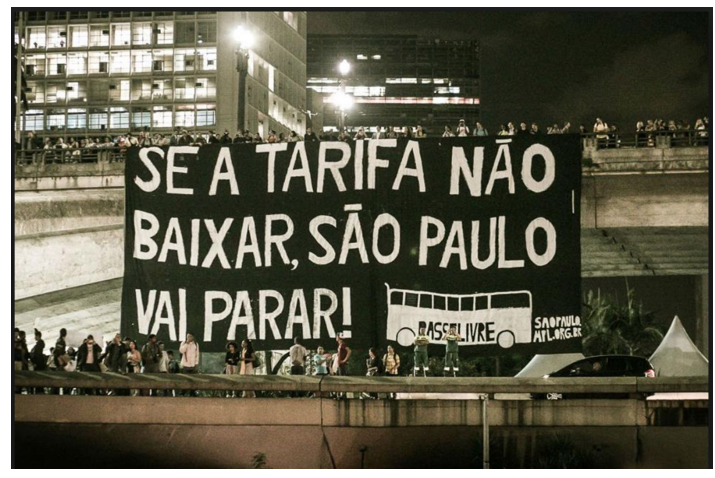

Fonte: Blog Lado Esquerdo. Autoria desconhecida ${ }^{15}$

Fonte: Crônicas das Jornadas de Junho. Autoria desconhecida ${ }^{14}$

\footnotetext{
${ }^{14}<$ https://medium.com/@amauri.gonzo/cr\%C3\% B4nicas-das-jornadas-de-junho-falc\% $33 \%$ A3o-e m-ato-\%C3\%BAnico-c3d75dzees28 >. Acesso em 26/08/2017.
}

15

$<$ http://ladoesquerdoo1.blogspot.com.br/2013/06 segue-aseguir-meus-relatos-confesso-que.html > Acesso em 26/08/2017. 


\section{capítulo 3. o MTST e os usos do direito}

"Pisa ligeiro, pisa ligeiro, Quem não pode com a formiga

Não atiça o formigueiro!" (Cantiga Popular entoada pelo MTST)

Apesar do MTST ter se tornado mais conhecido na cena política em 2013, o movimento já estava se organizando e se estruturando há muitos anos quando as Jornadas de Junho explodiram. Antes de passarmos ao breve relato e sistematização da sua história, concepções políticas e uso do direito, é importante destacar que o trabalho de reconstrução dos elementos políticos de um movimento - que este ano completa 20 anos - demanda uma atenção significativa; pois, tais elementos são fruto de um processo coletivo, repleto de diferentes avaliações, ênfases e memórias, muitas vezes ainda não sintetizadas pelo próprio movimento.

Em razão disso, foram escolhidos diferentes instrumentos de pesquisa, já abordadas na introdução desta dissertação; dentre eles, destacamos: (i) o registro das vivências nas ocupações e nos diferentes espaços do movimento, inclusive do relato direto dos militantes da coordenação do MTST - a saber, Guilherme Boulos e Josué Augusto do Amaral Rocha, durante a apresentação do movimento em uma atividade no Instituto Pólis, no dia 19 de março de 2017; e dos militantes Gabriel Simeone e Natália Szermeta, durante a apresentação do movimento aos participantes das brigadas do MTST em 02 de abril de 2017, no Casarão do Movimento, em Taboão da Serra; (ii) a análise dos textos e documentos produzidos pelo próprio movimento, sejam livros, textos internos, cartilhas, 
resoluções de encontros, manifestos e vídeos; (iii) análise dos textos acadêmicos, especialmente dissertações de mestrado e teses de doutorado que trataram do MTST; e, por fim, (iv) a análise do relato indireto obtido por meio de uma entrevista coletiva com os militantes Alex e Guilherme, além dos arquitetos Wagner e Alexandre, concedida à revista Crítica Marxista, em dezembro de 2001, e cuja leitura fora recomendada pelos próprios militantes do MTST.

\section{Breve histórico do MTST}

\section{Do campo ao urbano, do urbano à autonomia (1997-2003)}

O MTST surgiu em 1997 de dentro do MST (Movimento dos Trabalhadores Rurais Sem Terra), cujas avaliações políticas internas apontavam para a necessidade de articular um movimento que dialogasse diretamente com a população e com as demandas dos grandes centros urbanos (BENOIT, 2002; GOULART, 2011a; GOULART, 2011b; MARTINS, 2015; PEREIRA, 2017). No final da década de 1990, apesar do MST estar vivendo um momento de ascenso político fortíssimo - sendo considerado por muitos o maior e mais combativo movimento social existente na época ${ }^{16}$-, conjunturalmente, o Brasil estava se consolidando como um país efetivamente urbano, já que as cidades, desde a década de 70, acolhiam mais da metade da população brasileira. Imagine, então, que uma força política como o MST, um dos principais movimentos populares de resistência às políticas neoliberais do então Presidente da República Fernando Henrique Cardoso, focava suas estratégias de organização em torno de um sujeito político que, na década de 90, representava menos da metade da população do país... e, se durante alguns anos, o MST conseguiu de fato organizar famílias que viviam nas cidades para a luta pela reforma agrária (BENOIT, 2002), já nos primeiros anos da década de 90, este cenário começou a se transformar: mesmo para aquelas famílias que guardavam alguma relação com o campo ou tinham nascido e crescido em áreas rurais ou tinham pais e parentes com tal origem -,

\footnotetext{
${ }^{16} \mathrm{Na}$ opinião do professor Boaventura de Sousa Santos, em uma palestra na Universidade de Coimbra ministrada em 2006 e reproduzida em seu livro "Renovar a teoria crítica e reinventar a emancipação social" que o MST era o maior movimento social da América Latina.
} 
a vida rural já não aparecia como uma opção atrativa e mobilizadora e a demanda pela melhoria da qualidade de vida nas próprias cidades passou a ser cada vez mais comum entre a classe trabalhadora (BENOIT, 2002; MARTINS, 2015).

Foi a partir da compreensão deste cenário que, já durante a Marcha Nacional pela Reforma Agrária, Emprego e Justiça, realizada em fevereiro de 1997, os militantes do movimento que saíram das cidades à pé rumo à Brasília foram amadurecendo a ideia de construir uma frente de atuação urbana como forma de fortalecer as lutas populares e garantir uma maior base social para as mobilizações ${ }^{17}$ (BENOIT, 2002; GOULART, 2011a; MARTINS, 2015); esse processo foi muito particular da marcha que saiu da Praça da Sé, em São Paulo, rumo à Esplanada e, não à toa, a primeira experiência urbana do MST se deu na cidade de Campinas, no Estado de São Paulo (GOULART, 2011a) ${ }^{18}$.

Concluída em abril do mesmo ano, a Marcha foi um sucesso: contou com a presença de mais de 100 mil pessoas acompanhando o MST pelas ruas de Brasília e até hoje é um forte marco na história do movimento - mas nem por isso o projeto de criação de um foco de resistência urbana foi descartado. No entanto, a questão central que mobilizaria tal foco não foi imediatamente decidida; em suas discussões, os militantes do MST apontavam para dois caminhos: a construção de um movimento popular que dialogasse ou com a questão capital/urbano - do qual a moradia seria tema chave - ou com a questão capital/trabalho, cuja atuação se estruturaria de forma diferente daquela característica dos Sindicatos, apesar da questão ser a mesma (MTST - CARTILHA DE PRINCÍPIOS, s/d; GOULART, 2011a). Depois de um intenso debate, a primeira opção acabou sendo a escolhida - embora, ao longo dos anos, tenha ficado mais clara a imbricação teórica e prática dessas duas questões.

\footnotetext{
${ }^{17}$ Vale ressaltar que na tese de doutorado de GOULART (2011a), é relatado, a partir de dados colhidos de entrevistas com os militantes do MTST, que uma situação ocorrida no Pontal do Parapanema em 1994 foi uma marco importante para o início e desenvolvimento das discussões internas ao MST no que se refere à criação de uma frente urbana de atuação.

${ }^{18}$ Vale ressaltar que os relatos indicam que a decisão pela criação de um movimento urbano não foi uma decisão unânime no MST. Em entrevista realizada por Martins (2015), os militantes do MTST do Distrito Federal afirmam: "A decisão de criação do MTST partiu de uma parte do MST. O MST, como todo movimento, tem suas diferenças internas e correntes. Tinha um grupo mais ligado ao Gilmar Mauro, de São Paulo, que achava importante construir um movimento de atuação urbana e pensou que essa alternativa seria o MTST. Só que nesse surgimento inicial, em 1997/1998, a construção do MTST era feita como um braço urbano do MST. Embora não tenha sido bancada por todo MST. Foi por isso que o MTST não se nacionalizou, a princípio. Ele começou onde esse grupo interno tinha mais influência: São Paulo, Pernambuco, Pará. (RODA..., 2014 apud MARTINS, 2015).
} 
Assim, as primeiras experiências do movimento que posteriormente se identificaria como MTST começaram a ser organizadas na região de Campinas, a partir da ocupação de um terreno que deu origem à ocupação batizada de Parque Oziel ${ }^{19}$. Tal cidade foi escolhida, de acordo com o relato de um dos coordenadores do movimento, reproduzido em Goulart (2011a), em razão da "(...) proximidade com um grande centro urbano; carência habitacional da população; existência de terras desocupadas; pequeno número de movimentos populares e do fato de que, na época, estavam acontecendo, na cidade, lutas desarticuladas por moradia" (OLIVEIRA, 2001 apud GOULART, 2011a, p. 19). As primeiras 800 famílias ocupantes logo se tornaram 5.000 e, à medida que este número ia crescendo, passou a ficar claro não só o nível de precariedade com a qual a classe trabalhadora urbana convivia nas cidades, mas também o potencial mobilizatório e organizativo dessa nova estratégia do MST (BENOIT, 2002).

Entretanto, mesmo para o MST, que deslocou seus próprios militantes para darem corpo e organicidade à ocupação, a luta no espaço urbano se constituiu como um enorme desafio. Vale lembrar - como fez o militante Gabriel Simeone durante a sua apresentação sobre o MTST - que a militância do MST não estava inserida na dura realidade das cidades brasileiras, já que era forjada, em sua maioria, nas experiências das lutas agrárias e dentro de assentamentos rurais. Ainda assim, já nos primeiros anos da década de 2000, 0 movimento realizou novas ocupações na região metropolitana de São Paulo, a saber, a Anita Garibaldi, em Guarulhos e Carlos Lamarca, em Osasco (GOULART, 2011a; PEREIRA, 2017).

Até então, por conta do vínculo do movimento com o MST, atuação e leitura política do MTST localizavam-se no campo democrático-popular, protagonizado pelo Partido dos Trabalhadores (PT), pela Central Única dos Trabalhadores (CUT) e pelo próprio MST. Com a vitória eleitoral do PT e a ascensão do Presidente Luiz Inácio Lula da Silva ao Governo Federal, tal campo compartilhava uma sensação de entusiasmo e esperança. E, enquanto parte da esquerda organizada deslocava sua militância para acompanhar a posse e os primeiros dias do novo Presidente, o MTST fez uma grande

\footnotetext{
${ }^{19}$ Oziel Alves Pereira foi um dos camponeses mortos no Massacre de Eldorado de Carajás, em 17 de abril de 1996, quando policiais militares avançaram violentamente contra 1.500 sem-terras que faziam uma marcha e assassinaram 19 deles. Um relato tocante de tal episódio pode ser lido em "O Massacre - Eldorado de Carajás: uma história de impunidade", de Eric Nepomuceno (NEPOMUCENO; SALGADO, 2007).
} 
ocupação, denominada Santo Dias, em um terreno da Volkswagem em São Bernardo do Campo, cidade na qual o então Presidente havia se forjado politicamente no contexto das lutas sindicais. A ocupação chegou a acolher 4.000 pessoas, que voluntariamente se juntaram aos iniciais 300 ocupantes (GOULART, 2011a). Entretanto, tal dimensão não significou a abertura de diálogo com as instâncias governamentais: da parte do Governador Geraldo Alckmin, houve não apenas uma recusa, mas um ataque fortíssimo ao movimento e ao Presidente Lula - que dias antes tinha usado o boné do MST no Planalto; da parte do Presidente, não só não foi oferecido apoio à ocupação mas a sua reação foi negativa. Assim, alguns dias após a ocupação, o despejo foi realizado de maneira violenta e sem nenhuma alternativa aos ocupantes. Concomitantemente, em Guarulhos, o MTST se viu obrigado a sair da ocupação Anita Garibaldi, em razão do crescente embate com o poder local liderado pelo tráfico de drogas (PEREIRA, 2017) ${ }^{20}$.

Consolidou-se, assim, um grande momento de influxo ao movimento. O âmbito urbano que, em um primeiro momento, parecia abrir um novo campo de mobilização e organização social, começou a ser negativamente avaliado pelo MST - já que o saldo organizativo ante aos despejos parecia muito baixo. Por conta disso, nos primeiros anos da década de 2000, o MST decidiu pela sua retirada do MTST e desvinculou-se totalmente da sua organização (PEREIRA, 2017).

Assim, o MST e o MTST tornaram-se movimentos autônomos, apesar do compartilhamento de características e princípios semelhantes entre eles, relatado com clareza por militantes do MTST em entrevista concedida à Revista Crítica Marxista (BENOIT, 2002):

"O MTST, incondicionalmente, tem, dentro de si, o código genético do MST, e qual é, digamos, a célula-mãe do MST? É a sua independência, a sua independência de partidos políticos, de centrais sindicais, de governos; com todos se relaciona, de acordo com a conjuntura, com a luta específica; às vezes, se relaciona de uma forma conflitante, às vezes, harmônica." (BENOIT, 2002, p. 141).

\footnotetext{
${ }^{20}$ Depois dessa experiência, mais de 10 anos se passaram sem que o MTST voltasse à Guarulhos, visto que tal saída ficou marcada na história do movimento; durante o período em que esta dissertação foi escrita, no entanto, o MTST fez algumas ocupações em Guarulhos - uma delas gigantesca, chamada Povo Sem Medo de Guarulhos, com mais de 8 mil famílias - e tem tido um bom diálogo com a respectiva Prefeitura.
} 


\section{A construção de um movimento autônomo (2003-2009)}

Após a saída do MST, o MTST passou por um tempo de relativo isolamento político, afastando-se do campo democrático-popular e focando-se na sua reorganização interna. Mesmo com a sua organização e organicidade abaladas - tanto pelas derrotas das ocupações quanto pela saída do MST -, o MTST realizou em 2005, na cidade de Taboão da Serra, a ocupação de um terreno que originou a Ocupação Chico Mendes. Tal ocupação, apesar de ter sofrido uma reintegração de posse em 2006, rendeu importantes frutos ao movimento ${ }^{21}$, dentre os quais, destaca-se a reformulação da sua tática nas ocupações, que será melhor tratada ainda neste capítulo.

Aliado a isso, em 2007, o movimento decidiu que era preciso expandir sua área de atuação em termos geográficos, de maneira a dar início ao processo de 'estadualização' em São Paulo (GOULART, 2011a). Se até então o movimento focava suas ações em municípios da região metropolitana de São Paulo, a partir de 2007, ele passou também a mirar os terrenos periféricos e ociosos de cidades do interior paulista. Assim, neste período, observamos um forte impulso de atuação no movimento, especialmente pelo aumento das ocupações de terras por ele realizadas e pelo seu espraiamento em direção a diferentes territórios. Como já mencionado, se até 2003 o movimento tinha realizado as Ocupações Parque Oziel em Campinas (1997), Anita Garibaldi em Guarulhos (2001), Carlos Lamarca em Osasco (2002) e Santo Dias em São Bernardo do Campo (2003), a partir de 2004, ele inaugurou uma série: Rosa Luxemburgo em Osasco (2004), Chico Mendes em Taboão da Serra (2005), João Cândido em Itapecerica da Serra (2007), Frei Tito em Campinas (2008), Silvério de Jesus em Embu das Artes (2008), Terra e Liberdade em Mauá (2008) e Zumbi dos Palmares em Sumaré (2008) (GOULART, 2011a).

Ademais, também como estratégia de ampliação da sua influência e atuação, foi neste momento que o MTST começou a fazer os bloqueios de rodovia, popularmente conhecidos como "trancamentos", com o objetivo de interromper, ainda que

\footnotetext{
${ }^{21}$ Como aponta GOULART: "as ocupações Chico Mendes e João Cândido representaram um novo patamar de organização e elaboração interna de suas [do MTST] ações e prioridades. Mudou o desenho da ocupação, a estrutura organizativa, as relações internas e a forma de negociação e pressão sobre os governos se aprimoraram. De outro lado, o Estado aprimorou o tipo de relação que estabeleceria com o movimento, passando da não aceitação das ações e da determinação do despejo para a negociação (...)" (GOULART, 2011a, p. 44).
} 
momentaneamente, a circulação de mercadorias e mão-de-obra nas principais vias de trânsito do Estado e, assim, trazer grande prejuízo aos capitalistas (MTST - CARTILHA DE PRINCÍPIOS, s/d, pg 05). Tal estratégia, apesar de muitas vezes ter um caráter mais simbólico (PEREIRA, 2017), implicou em um aumento da visibilidade do movimento.

Bem avaliada pelo MTST, o processo de estadualização abriu espaço para, já durante o Encontro Estadual em maio de 2009, a sua 'nacionalização' se tornar uma meta (GOULART, 2011a; GOULART, 2011b). Vale ressaltar que, apesar do fato de, em anos anteriores, o MTST ter se expandido de maneira dispersa para outras capitais, esta nacionalização iniciada em 2009 foi uma estratégia política organizada, que visava também à garantia de um caráter unificado às lutas do MTST em diversos Estados - o que ia além da mera presença neles - e a formulação de estratégias e ações voltadas à esfera federal. De lá para cá, o MTST foi se organizando em diferentes Estados, em um processo repleto de indas e vindas, até chegar aos 11 onde atualmente está consolidado, a saber, Rio de Janeiro, Paraná, Amazonas, Rio Grande do Sul, Tocantins, Goiás, Roraima, Pernambuco, Ceará, Minas Gerais e São Paulo, sendo estes quatro últimos os Estados nos quais o movimento tem maior inserção, além do Distrito Federal.

\section{Um novo campo político, uma nova inserção (2009 em diante)}

Nos últimos anos, o MTST foi, quase que à força - e à revelia de alguns setores de esquerda, sejam aqueles mais vinculados ao projeto democrático-popular, sejam aqueles mais alinhados à esquerda radical -, conquistando espaço na conjuntura política não só local mas também regional e nacional.

Seu contínuo crescimento era esperado pela militância, visto que suas ações se direcionavam à ampliação da sua base e à dinamização das lutas urbanas; porém, a partir de 2010, tal crescimento se tornou ainda mais intenso do que o esperado. Na avaliação do MTST, isso se deveu à crise que se instalou e ainda hoje vem se aprofundando nas cidades brasileiras nos últimos anos e que tem acarretado na piora das condições de vida urbanas e tornado as cidades brasileiras verdadeiras "máquinas de formar sem-tetos" (BOULOS, 2015b, p. 12). A ocupação de terras pela classe trabalhadora acabou parecendo cada vez mais viável - ou cada vez mais inevitável - e, a partir da identificação desta demanda, mais ocupações organizadas pelo movimento nasceram e se multiplicaram. Exemplo disso 
foram as ocupações Santa Cristina, em Santo André, e Che Guevara, em Taboão da Serra, ambas realizadas em 2010 .

Assim, ao longo dos primeiros anos da década de 2010, o MTST foi se construindo enquanto força social atuante nas lutas urbanas. Em 2010, o movimento participou da criação e passou a compor a CSP Conlutas, central sindical da qual fez parte até 2012, quando, em razão de desavenças com o Partido Socialista dos Trabalhadores Unificado (PSTU), decidiu retirar-se (CARTA..., 2012).

O fortalecimento do MTST como movimento político e o aumento da sua base não se deram, no entanto, sem grandes enfrentamentos. O levantamento documental realizado evidenciou reiteradas ações repressivas e criminalizatórias movidas contra o movimento por parte, principalmente, dos agentes do Estado. Ressalta-se, neste sentido, a acusação de ameaça feita em face do MTST pela juíza responsável pelo processo de julgamento da ação de reintegração de posse da Ocupação Novo Pinheirinho do Embu, em 2012 (JUÍZA É..., 2012). Tal acusação gerou comoção entre os magistrados, que soltaram um manifesto em apoio à juíza e afirmaram que "se a sentença não agradou a todos, é porque não é tarefa do magistrado se preocupar em agradar, mas em buscar o justo" (JUÍZA É..., 2012). A sentença, ressalta-se, impunha multa diária de $\mathrm{R} \$ 50.000$ reais ao MTST, caso as 8 mil famílias não desocupassem imediatamente a área (JUÍZA É..., 2012; ESCANDALOSO..., 2012).

Em 2013, o movimento somou-se às manifestações lideradas pelo MPL (O MTST SE JUNTA..., 2013). A partir de então, ele passou a ter maior visibilidade e projeção na cena política, inaugurando um novo período de sua trajetória. No cenário mais amplo, ganhou espaço no processo político inaugurado pelas Jornadas de Junho por ser um movimento que, apesar de guardar semelhanças com a forma-partido tradicionais e mesmo com os movimentos sociais do período da redemocratização, aparecia munido de uma nova capacidade ofensiva desvinculada de pretensões eleitorais e de uma leitura de realidade crítica e de esquerda, mas não necessariamente antagonista ao programa democrático-popular liderado pelo Partido dos Trabalhadores. Na avaliação do movimento, o fato de 2013 ter desencadeado, entre outras coisas, a ascensão de uma nova direita antipartidária e antipetista, tornou-se urgente a construção de um novo campo político que conseguisse avaliar os avanços e limitações dos governos petistas, para assim criar uma nova força social disposta a disputar a sociedade. Nesse sentido, ele passa a 
tentar travar diálogos tanto com setores da esquerda críticos ao PT como com setores a ele alinhados. Assim, o MTST vai se posicionando no cenário político como uma força que luta pela moradia, mas que, ao considerá-la num espectro mais ampliado da luta de classes, assume uma forte atuação também na disputa dos processos políticos mais amplos da esquerda.

Ao mesmo tempo, o movimento não deixou de lado sua estratégia de ocupações de terrenos urbanos. Assim, em agosto do mesmo ano, ele faz importantes ocupações no Município de São Paulo, especificamente em Paraisópolis, em um terreno cercado por prédios luxuosos, dando origem à Ocupação Faixa de Gaza (OCUPAÇÃO FAIXA DE GAZA..., 2013). Meses depois, o MTST organiza as ocupações Dona Deda (no Parque Ipê), Capadócia (no Jd. Ingá) e Vila Nova Palestina (no M’Boi Mirim) (CONQUISTAS..., 2014), esta última muito conhecida por ser considerada uma das maiores ocupações de terras no Município: localizada em um terreno de 1 milhão de metros quadrados às margens da Estrada do M'Boi Mirim, no extremo Sul de São Paulo, a ocupação foi realizada em 29 de novembro de 2013 e chegou a alojar nada menos do que 8.000 famílias - e atualmente conta 2 mil unidades habitacionais em processo de licenciamento para atender as demandas das famílias organizadas pelo movimento, no local (MANIFESTO DE APOIO..., 2014).

Ainda em 2013, o movimento também cumpriu um importante papel na organização da resistência da Ocupação Estaiadinha, localizada em um terreno municipal próximo à Marginal Tietê, na Zona Norte de São Paulo. Tal ocupação começou a partir de iniciativas espontâneas de moradores da região e acabou por ter um mandado de reintegração de posse expedido em desfavor das cerca de 200 famílias ocupantes; o MTST, então, foi chamado a colaborar com os processos de resistência e negociação - de início infrutíferas, mas que, após 10 dias de acampamento das famílias em frente ao Departamento Estadual de Trânsito de São Paulo (DETRAN), resultaram no atendimento habitacional provisório e definitivo para os ocupantes (ESTAIADINHA..., 2014).

Foi no início de 2014, no entanto, que o MTST avalia ter atingido o auge da sua notoriedade política. A partir do ganho de espaço que o processo político inaugurado pelas Jornadas de Junho lhe proporcionara, aliado à enorme quantidade de trabalhadores que passaram a compor a base das ocupações realizadas ao final de 2013, o movimento se consolidou enquanto nova referência política na luta urbana. Isso ficou evidente com a 
ocupação Copa do Povo, localizada em um terreno a 4 quilômetros da Arena Corinthians, onde, poucos dias depois, seria realizada a cerimônia de abertura da Copa do Mundo (A OCUPAÇÃO..., 2014). A ocupação em si, que reuniu milhares de famílias já nos seus primeiros dias, somada às dezenas de atos e negociações políticas realizadas pelo movimento nos dias imediatamente posteriores a ela, trouxeram uma enorme visibilidade política para o movimento e o fortaleceu enquanto força política no Município, seja em torno da pauta da moradia, seja em torno de pautas mais gerais do cenário político, já que a Ocupação Copa do Povo também teve um caráter de denúncia das violações de direitos e excesso de gastos públicos em razão da recepção da Copa do Mundo pelo Brasil e impulsionou a campanha "Copa Sem Povo, Tô na Rua de Novo" encabeçada pelo MTST com os movimentos da Resistência Urbana.

Ainda naquele ano, o movimento organizou a Ocupação Portal do Povo, novamente na região do Morumbi, em um terreno da construtora Even, na qual, só na primeira semana, recepcionou 4 mil famílias (PM FAZ REINTEGRAÇÃO..., 2014), além da Ocupação Carlos Marighella na Granja Viana (OCUPAÇÃO CARLOS MARIGHELLA..., 2014). Atualmente, o MTST também conta com a Ocupação Povo Sem Medo do Capão e Ocupação Novo Sonho, localizada próxima à Ocupação Nova Palestina, na estrada do M'Boi Mirim, além das ocupações localizadas na Região Metropolitana de São Paulo, como a Ocupação Povo Sem Medo do Embu e Ocupação Povo Sem Medo e Hugo Chavez, ambas em Guarulhos.

É preciso ressaltar que, em 2015, o cenário político do país - caracterizado sobretudo por um arranjo das forças políticas conservadoras e consequente impeachment da Presidente eleita Dilma Roussef - impôs aos movimentos sociais de esquerda uma agenda intensa de resistência e enfrentamento. Neste sentido, o MTST e partidos políticos, movimentos sociais e centrais sindicais que, no geral, dialogam com um campo político crítico ao campo democrático popular ${ }^{22}$, constituíram a Frente Povo Sem Medo, de âmbito nacional, que atualmente tem sido a principal frente de atuação do MTST. Tal Frente defende um posicionamento político que acredita na necessidade de uma renovação da esquerda brasileira, mais combativa e com maior capacidade de

\footnotetext{
${ }^{22}$ Vale ressaltar que também participam da Frente Povo Sem Medo alguns movimentos sociais cuja atuação está mais afinada com o campo democrático popular - como é o caso da UNE, PT e CUT - pois, no geral, optaram por compor tanto a Frente Povo Sem Medo quanto a Frente Brasil Popular.
} 
mobilização popular, que consiga trazer para a agenda política temas ligados a privilégios históricos que permaneceram intocados ou pouco tocados durante os 13 anos de governo PT, como é o caso da reforma tributária, da legalização do aborto, da desmilitarização da polícia, do genocídio da população negra nas periferias, do sistema carcerário, entre outras; é um frente que segue as avaliações do MTST aqui já citadas, qual seja, a necessidade de avaliar os avanços e retrocessos dos governos do PT e, com base nisso, construir um campo de esquerda que tenha capacidade de dar novas e diferentes respostas ao cenário político que avança sobre os direitos dos trabalhadores.

O MTST, especificamente, entende que este ideal de renovação da esquerda é um dos três maiores desafios colocados para a esquerda brasileira atualmente ${ }^{23}$. Ao lado dele, estão a retomada do trabalho de base e a construção de processos unitários de lutas e mobilizações políticas que, juntos, têm sido norteadores da atuação do movimento nos últimos anos. Em relação ao trabalho de base, o MTST avalia que nos últimos 20 anos, a maior parte da esquerda deixou de fazê-lo e assim perdeu a capacidade de mobilizar e de representar as pessoas; de acordo com sua liderança Guilherme Boulos, em entrevista à Rede Marxista de Informação, a esquerda, a partir do momento que optou pela disputa institucional, deslocou sua atuação dos bairros para os gabinetes e gerou tanto uma perda de capilaridade social como abriu espaço para que novas forças sociais, como as Igrejas Evangélicas Pentecostais, tomassem os espaços das periferias urbanas. Neste sentido, o MTST tem um direcionamento claro de priorização do trabalho político com sua base social e aposta nas resistências e mobilizações como principais instrumentos de negociação e pressão política ${ }^{24}$. Quanto à necessidade de construção de processos unitários de lutas, esse esforço pode ser observado na própria criação da Frente Povo Sem Medo e na sua atuação em conjunto com Frente Brasil Popular nos processos de resistência ao impeachment da Presidente Dilma e ao enfrentamento às políticas propostas pelo Governo Temer e pelo Congresso Nacional, por entendê-las prejudiciais aos trabalhadores. Assim, apesar das Frentes acreditarem em projetos políticos diferentes, desde 2015 elas vem compondo conjuntamente ações, campanhas e atos que têm mobilizado milhares de pessoas em todas as capitais brasileiras, como foi o caso do ato

\footnotetext{
${ }^{23}$ Estes desafios foram apresentados por Guilherme Boulos durante uma atividade no Instituto Pólis no dia 19 de março de 2017.

24 Para mais, ver a entrevista de Guilherme Boulos para a Rede Marxista de Informação em https://www.facebook.com/mtstbrasil/
} 
contra a Reforma da Previdência, no dia 15 de março de 2017, e da Greve Geral do dia 28 de abril de 2017.

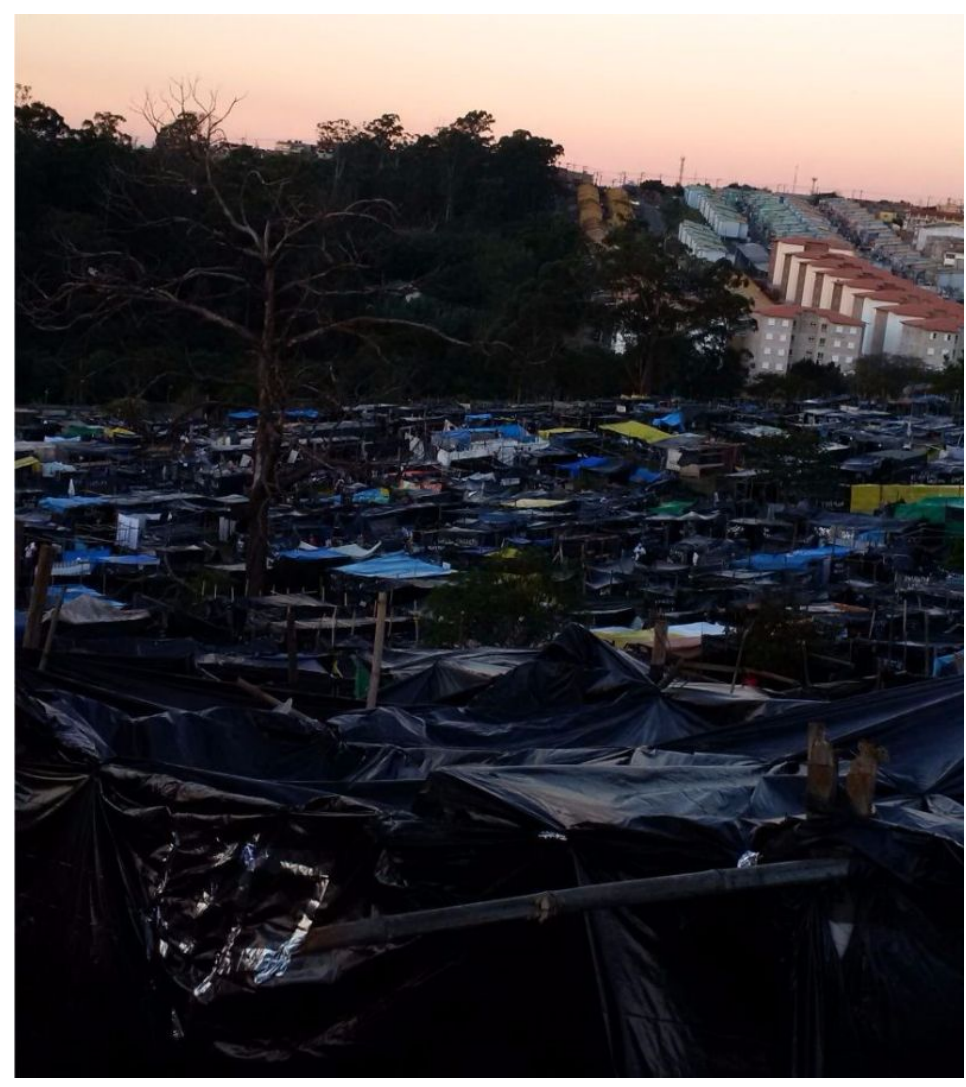

Foto da Ocupação Povo Sem Medo de Guarulhos. Tal ocupação, realizada pelo MTST em 03/06/2017, atualmente acolhe cerca de 8 mil pessoas. Fonte: Brigada da Comunicação do MTST. Autoria desconhecida.

\section{Concepções políticas do MTST}

Ao longo do breve histórico acima relatado, algumas orientações políticas do MTST já foram evidenciadas, porém parece importante ressaltar (i) o caráter classista do movimento, (ii) a priorização da ação direta e crítica à luta institucionalizada, (iii) a sua visão sobre a Reforma Urbana e (iv) a ocupação de terrenos como estratégia fundamental do movimento. Tais orientações se entrelaçam e relacionam, como tentaremos a seguir sistematizar. 


\section{Ação direta e distanciamento institucional}

Comecemos pela sua posição crítica quanto à luta institucionalizada - uma forma de luta que, conforme vimos no capítulo or desta dissertação, foi marcante entre os movimentos sociais ligados à Reforma Urbana. O MTST tem um posicionamento firme de distanciamento dos espaços institucionais de participação, tanto é que ele não se inseriu oficialmente em espaços oficiais de participação como o Conselho Nacional das Cidades ou o Conselho Gestor do Fundo Nacional de Moradia Popular, na esfera federal; as Conferências Estaduais da Cidades, na esfera estadual; ou como as audiências públicas de revisão do Plano Diretor do Município de São Paulo e da Lei de Parcelamento, Uso e Ocupação do Solo, os órgãos consultivos e/ou deliberativos como a Câmara Técnica de Legislação Urbanística, as Conferências Municipais da Cidade, os Conselhos Gestores de Zonas Especiais de Interesse Social (ZEIS), o Conselho Municipal de Habitação, entre outros existentes no âmbito municipal.

$\mathrm{Na}$ avaliação do movimento, os espaços participativos ligados ao Estado acabam por subordinar as lutas urbanas aos desenhos e limitações institucionais, o que faz com que o espectro de reivindicação e negociação se restrinjam de tal maneira que seus avanços sejam pouco significativos, além de consumir a energia e o tempo dos seus militantes, que poderiam estar engajados em outras lutas. Isso não quer dizer, entretanto, que tais espaços sejam totalmente negados; o movimento os considera importantes no seio da atuação de entidades e ONGs, por exemplo, mas acredita que não devem ser espaços estratégicos de atuação dos movimentos sociais. Destacamos aqui dois fatores que parecem ter sido importantes para a consolidação de tal posicionamento.

O primeiro se relaciona ao fato do MTST ter herdado algumas práticas e concepções políticas do MST - um movimento que sempre prezou tanto pela luta direta, por meio das ocupações de terra, quanto pela independência política, garantida também pelo distanciamento dos seus militantes das disputas de cargos políticos e eleitorais (BENOIT, 2002).

O segundo se relaciona com o fato do MTST ter tido uma trajetória diferente de outros movimentos sociais de moradia que, em geral, têm uma atuação mais vinculada a um Município (podendo se expandir para outros territórios). Como apontado no breve relato histórico presente neste capítulo, a história do MTST no Estado de São Paulo se 
caracteriza por uma atuação espraiada em diferentes territórios - Campinas, Guarulhos, Taboão da Serra, Osasco, São Paulo -, cuja duração era intermitente, marcada pelos períodos de organização e resistência das ocupações. Em razão disso, durante muitos anos, o MTST foi considerado um movimento "estrangeiro" nos Municípios, como relatado no trabalho de Miagusko (2008):

"(...) o Poder Público municipal está acostumado com movimentos de lógica municipalista. De movimentos que formam sua base em determinado município, em geral com pretensão de eleger um parlamentar numa eleição seguinte, né, ficam mantendo relação de cadastramento, de reuniões, de relação com a Prefeitura e ganham espaço na política institucional da região (...) quando falam que o MTST é estrangeiro o que estão dizendo na verdade é que o MTST é estrangeiro a uma lógica de fazer política. E somos mesmo." (entrevista de militante do MTST in MIAGUSKO, 2008, p. 194)

Neste sentido, por permanecer nos territórios por pouco tempo - já que a reintegração de posse quase que inevitavelmente acontecia - e por não alimentar o jogo político particular de cada território, o MTST foi se forjando enquanto movimento político à margem dos espaços institucionais oficiais e consolidou-se como crítico a tal estratégia política levada a cabo por outros movimentos.

Entretanto, se até pouco tempo este era um posicionamento quase que absoluto do movimento, atualmente parece que, certo das limitações dos espaços institucionais e do erro estratégico que seria priorizá-los nos processos de luta, o MTST se permite a considerar ocupá-los eventualmente, a depender dos rumos da conjuntura, sem que isso incorra numa contradição. Nos últimos anos, em razão do seu destaque enquanto força política, o MTST tem sido convidado a participar de espaços institucionais por outros movimentos sociais ou mesmo por instituições que queiram ampliar seus horizontes de debate, e, em razão disso, tem se debatido a importância de sopesar os limites e possibilidades que a esfera institucional pode proporcionar no caso concreto. Entretanto, tais debates ressaltam sempre a atuação institucionalizada como uma prática 
circunstancial às formas de lutas priorizadas pelo movimento: a ação direta, traduzida especialmente pelas ocupações de terrenos urbanos.

"As formas de atuação do MTST estão centradas na luta direta contra nossos inimigos. Isto é importante porque nos diferencia da maioria dos movimentos urbanos, que optaram por focar suas ações na participação institucional: negociações de projetos com o Estado, participação em Conselhos (conselho de habitação, das cidades, orçamento participativo, etc.) e parcerias com os governos. Embora, o MTST também saiba negociar, para nós esta parte do processo está sempre em função das mobilizações e ações diretas de pressão." (MTST - CARTILHA DE PRINCÍPIOS, s/d, pg.05 - grifo nosso)

\section{Ocupações como estratégia de organização da classe trabalhadora}

A ocupação de terrenos urbanos é a principal estratégia do MTST e, por isso, grande parte das suas ações estão voltadas à organização e realização do trabalho político nas ocupações (MTST - CARTILHA DE PRINCÍPIOS, s/d). Na concepção do movimento, são metas fundamentais das ocupações: formar novos militantes a partir da qualificação e inserção política dos coordenadores eleitos pelos acampados; criação de um território organizado e mobilizado coletivamente, no qual sejam priorizadas soluções e construção de espaços coletivos; garantir um processo de territorialização em locais onde o movimento pode ganhar visibilidade e aprofundar seu trabalho político; ampliar o espectro do trabalho e da referenciação política do MTST para as comunidades do entorno das ocupações (MTST - CARTILHA DE PRINCÍPIOS, s/d).

Neste sentido, as ocupações, apesar de se relacionarem diretamente com os processos de luta pela moradia, representam, no entendimento do MTST, epicentros de organização da sua base social, a classe trabalhadora.

Por conta disso, o MTST entende primordial o planejamento e acompanhamento de todas as fases da ocupação, desde o ato de adentrar a um terreno específico até os últimos minutos da resistência, nos casos de reintegrações de posse. Em relação ao 
planejamento da ocupação, a regra é que o próprio movimento conduza a sua realização ainda que ele não se oponha a assumir trabalhos de organização política de territórios previamente ocupados, como foi o caso da Ocupação Estaiadinha, na região central de São Paulo - pois os locais que as ocupações são feitas não são aleatórios; o movimento entende que eles devem ser escolhidos com base em alguns critérios.

O primeiro critério de escolha é que a ocupação esteja localizada em um espaço com grande demanda popular pela moradia - o que não quer dizer que no território precise haver uma demanda já organizada. Isso porque, quando o MTST entra em um terreno, as famílias e os militantes que participam do ato da ocupação normalmente já estão acampadas em outros terrenos, por isso as famílias que realmente comporão a nova ocupação são aquelas residentes no entorno do terreno onde ela ocorreu. Foi o que observamos quando da entrada do MTST no terreno onde hoje encontra-se a Ocupação Novo Sonho: as famílias que realizaram a ocupação eram, em sua maioria, famílias já cadastradas na Ocupação Nova Palestina; e, por serem de outra ocupação, tais famílias tinham a tarefa de 'consolidar' a nova ocupação, ou, seja, garantir que, durante as primeiras 48 horas de ocupação, não só o terreno estivesse lotado, mas também que fosse massivamente realizado o que o MTST chama de 'trabalho científico': um trabalho feito a partir da divisão de militantes em duplas ou trios para divulgar a ocupação na comunidade ao redor mediante o diálogo direto nas residências, a distribuição de panfletos, a utilização de carros de som, etc.

$\mathrm{Na}$ experiência do MTST, durante essas primeiras 48 horas é que ocorre o fluxo mais intenso de adesão da comunidade à ocupação, cujas famílias integrantes passam a ser aquelas instaladas na própria região. Por isso, a ocupação de um novo terreno urbano pelo MTST só faz sentido na medida em que ocorrer em territórios que apresentem uma demanda significativa pela moradia, pois, do contrário, as ocupações ficariam vazias, já que as famílias registradas em uma ocupação não são transferidas para outra, a não ser que por interesse próprio.

Vale ressaltar que, por conta deste primeiro critério, grande parte das ocupações do MTST acontece nas periferias urbanas, até porque nelas também são mais recorrentes os casos de grandes terrenos não edificados abandonados, condição necessária para a massificação da intervenção. Entretanto, o MTST já organizou ocupações em áreas 
nobres ou centrais da cidade de São Paulo, como foi o caso das Ocupações Portal do Povo e Faixa de Gaza, ambas no Morumbi.

Um segundo critério para a escolha da área das ocupações que pudemos apreender ao longo do trabalho de campo se relaciona com as condições jurídicas e urbanísticas de cada imóvel. Isso porque, no entendimento do movimento, o prévio conhecimento e avaliação de tais condições influencia no processo mais ou menos vitorioso de resistência popular. Afinal de contas, saber se a área é pública ou privada, se tem dívidas de IPTU ou mesmo se já foi alvo de ocupações anteriores por outros movimentos, permite a antecipação de linhas de defesa jurídica, de pautas para negociação com o poder público, e de conteúdo para o convencimento dos acampados, os quais são fundamentais para a os processos mais imediatos de resistência. Ressaltamos aqui um exemplo por oposição, isto é, que demonstra como a falta de informações jurídico-urbanísticas prévias sobre o terreno pode dificultar os processos de resistência futuros: em Guarulhos, em 2017, o MTST realizou uma ocupação de um terreno sem levantar informações precisas sobre ele; horas depois, entretanto, sobreveio a informação de que o terreno era público e estava há anos afetado para a instalação de um Pólo Tecnológico cujas atividades trariam um impacto social positivo para a região; por conta disso, a reintegração de posse foi rapidamente decretada pela Justiça e as condições de negociação com a Prefeitura, para a manutenção das famílias no mesmo terreno, foram infrutíferas. Assim, mesmo com uma adesão quantitativamente enorme de famílias à ocupação, o cumprimento da reintegração de posse não tardou a vir - e veio, ressalta-se, de maneira violenta.

O conhecimento das condições urbanísticas e jurídicas são, neste sentido, relevantes para a garantia do processo de consolidação e de desenvolvimento da ocupação. Isso porque a prática do MTST para reivindicar o atendimento das demandas habitacionais dos seus acampados é lutar para que, a partir das suas ocupações - e de preferência no próprio terreno onde elas se localizam - seja viabilizado o assentamento definitivo das famílias a partir de empreendimentos habitacionais planejados. Por conta disso, o conhecimento, por exemplo, do zoneamento da área, da existência de pendências jurídicas envolvendo o terreno, podem facilitar a negociação com o Poder Público e potencializar a chance do atendimento das demandas.

Entretanto, não são apenas as condições jurídicas e urbanísticas que importam; a compreensão mais ampliada da condição do terreno em face dos processo de especulação 
imobiliária na cidade, e as possibilidades de articulação entre o terreno pretendido com outras áreas ocupadas, também são fundamentais. Isso porque, sendo o MTST um movimento que coloca como seu maior objetivo "a luta contra o capital e o Estado que representa os interesses capitalistas" (MTST - CARTILHA DE PRINCÍPIOS, s/d, p. o3), ele vai orientar todas as suas ações contra a cidade desigual que o capitalismo impõe e para a denúncia e apropriação, pela classe trabalhadora, dos chamados "latifúndios urbanos".

"A apropriação coletiva do espaço urbano consiste, principalmente, na ocupação de espaços utilizados para a especulação imobiliária, expressão da apropriação privada da cidade. A ocupação dos "latifúndios urbanos" é primordial para a construção de uma 'dimensão comunitária do espaço contra sua situação de objeto da especulação financeira', onde é possível desenvolver formas de poder popular para resistir ao caráter privatista da cidade capitalista." (GOULART, 2011a, p. 74)

Assim, estando em um terreno com grande capacidade de massificação e de consolidação, o MTST garante as condições ideais para o desenvolvimento do seu trabalho político na ocupação. Tal trabalho é complexo, um misto de uma atuação rotineira - que politiza desde a preparação do almoço até a construção dos barracos - com a preparação de espaços políticos específicos, como os atos, mobilizações, assembleias, etc, cujos objetivos são voltados tanto para a formação política dos acampados como para a criação e compartilhamento de uma identidade coletiva de classe entre eles.

Destaca-se, neste sentido, o papel que as 'cozinhas' das ocupações desempenham. Nossa observação da Ocupação Novo Sonho confirma o que o MTST afirma: a cozinha é o primeiro espaço coletivo construído após a ocupação de um terreno (BOULOS, 2015a). Invariavelmente, é o único lugar da ocupação que, a princípio, tem luz e água corrente além do café quente -, de maneira que acaba se constituindo como um espaço de reunião e encontro dos acampados. Assim, as cozinhas se tornam "o coração" de uma ocupação. Lá, sempre terá alguém do movimento e sempre haverá espaço para acolhimento dos acampados. Isso fica ainda mais proeminente quando, com a consolidação da ocupação e a divisão das famílias em "Gs" (grupos), são montadas diversas cozinhas no terreno, cada 
qual correspondente a um "G". E, considerando que os "Gs" representam a unidade mais básica de organização dos acampados, as cozinhas se tornam o local privilegiado de encontro entre eles, onde são doados e divididos os alimentos, onde ocorrem as reuniões, enfim, onde os acampados podem desempenhar processos de coletivização e construção de uma identidade afetiva e subjetiva, tão fundamental ao movimento. ${ }^{25}$

"As ocupações, portanto, cumprem um duplo papel na estrutura organizativa e na proposta política do movimento: construção não só de resistência territorializada, mas também de espaços de exercício de coletivização e poder popular, por isso têm papel central na organização do MTST, embora haja uma intensa rede de relações fora dele, como é o caso dos núcleos. Mas é nas áreas ocupadas que há formação política mais intensa, decisões sobre as ações coletivas, representação para as outras instâncias do movimento em níveis estadual e nacional. A ocupação centraliza as atenções e expande a potencialidade de luta, na medida em que congrega todo o conjunto de relações sociais que emergem desta forma de luta pela moradia." (GOULART, 2011a, pp. 74-75)

Vale ressaltar que a constituição de tais espaços ganha ainda mais importância na medida em que as ocupações do MTST não são organizadas de maneira a servirem ao acolhimento definitivo das famílias. De fato, as famílias não são incentivadas pelo MTST a se desvencilharem dos espaços de moradia já constituídos para se alojarem definitivamente nas ocupações.

A orientação tática desenvolvida pelo MTST de não acolher definitivamente as famílias em suas ocupações foi estabelecida em 2007. Como já ressaltado no breve histórico do movimento, retratado no capítulo o2 desta dissertação, o MTST passou por um momento de refluxo durante os primeiros anos da década de 2000 , período no qual o movimento começou a perceber os processos de reintegração de posse como resposta inevitável do Poder Público às suas ocupações. Ao mesmo tempo, o movimento avaliou que o saldo organizativo diante do cumprimento da reintegração de posse era muito baixo

\footnotetext{
${ }^{25}$ Não à toa que, com frequência, as cozinheiras são eleitas as primeiras coordenadoras dos "G"s.
} 
- pois, não raro, significava uma grande perda material para as famílias, além de um trauma, visto que a maioria dos cumprimentos era (e ainda hoje, é) marcado pela violência e descaso das autoridades públicas. Aliado a isso, também sobreveio a constatação de que condições de habitabilidade que geralmente caracterizam uma ocupação beiram à precariedade, visto que mesmo organizadas, as ocupações se dão em locais com nenhum sistema de abastecimento de água, saneamento básico, iluminação, etc. O resultado disso é que, invariavelmente, as ocupações tornavam-se novos bairros precários e perdiam um potencial de luta voltada à conquista de melhores condições de moradia e vida para a classe trabalhadora:

"A metodologia do MTST implica não estimular as famílias a romperem esse vínculo precário de moradia. Se as milhares de famílias que participam de ocupações, buscando uma condição mais digna de vida, fossem morar definitivamente lá, com todos os seus pertences, o resultado seria a criação em larga escala de novas favelas." (BOULOS, 2015b, p. 30)

Assim, a partir de 2007, essa nova tática organizativa das ocupações começou a ser usada pelo MTST e a diferenciá-lo de outros movimentos sociais de moradia (BOULOS, 2015b). As famílias inscritas na ocupação passaram, então, a construir e manter seus barracos, se vinculando à organização do MTST por meio das atividades das assembléias, formações, reuniões de "Gs", atos e manifestações. Cada coordenador de "G", eleito pelos acampados, tornou-se responsável pelo controle da participação dos acampados, os quais, caso não tivessem acompanhando assiduamente as atividades da ocupação, poderiam perder o espaço onde estavam construídos seus barracos (COMO ORGANIZAR...s,/d). A construção de uma identidade coletiva e de pertencimento dos acampados, desde então, passou a ser estimulada a partir de um trabalho político consciente e rotineiro do MTST, o que foi observado e acompanhado durante a pesquisa de campo e é reforçado pelo fato dos acampados já compartilharem de um primeiro traço comum, que é a qualidade de moradores da periferia do entorno.

Neste contexto, o MTST organiza politicamente as ocupações para que elas se constituam enquanto espaços de referência de desenvolvimento de processos políticos 
tanto para aqueles nela estejam cadastrados quanto para aqueles que, apesar de não inscritos, simpatizem com o movimento e com suas propostas. Este também é um ponto relevante das ocupações realizadas pelo MTST: elas são organizadas de maneira a promover uma integração direta com a comunidade do entorno. Diferentemente de ocupações que, até por medida de segurança precisam se isolar do entorno - como é o caso de muitas ocupações no centro de São Paulo, que, não raro, precisam ter porteiros, portões e trancas -, as ocupações do MTST ficam abertas a qualquer pessoa que queira conhecê-las. Nenhuma das ocupações visitadas durante a pesquisa é murada ou tem restrição de acesso - apesar de contar com equipes de segurança em razão de possíveis ofensivas. Assim, as ocupações são organizadas também para se constituírem enquanto referência política nos bairros:

"(...) Por isso, a referência de nossa atuação tem que ir além da ocupação, ampliando-se para as comunidades próximas. (...) Precisamos expandir iniciativas como essas para ampliar nossa referência nas periferias. Assim, a ocupação seria um ponto de partida para um trabalho muito maior. (MTST - CARTILHA DE PRINCÍPIOS, s/d, p. i1)

A ideia é que as ocupações se tornem epicentros de processos de resistência e politização nos bairros, a partir da sua abertura aos moradores do entorno em atividades de formação política, de atrações culturais, de atendimentos de saúde e de mutirões jurídicos realizados pelas Brigadas de Apoio ao MTST. Ademais, tal trabalho segue articulado com a constituição dos chamados 'Bairros Sem Medo', uma articulação política já existente no Capão Redondo, na Pompéia e em Itaquera, na qual diversos movimentos e coletivos que atuam nos bairros, dentre eles o MTST, se reúnem e discutem formas de organização de processos de resistência popular a partir de atividades de formação e mobilização nos bairros.

\section{MTST e a Reforma Urbana}

A Reforma Urbana é uma bandeira de luta reivindicada pelo MTST. Ela consta em seus documentos (cartilhas de princípios, cartas abertas), no discurso dos coordenadores 
nacionais, estaduais e de ocupações, além de ser uma palavra de ordem evocada em manifestações e ser tema de Jornadas de Lutas do MTST.

De maneira geral, podemos dizer que o projeto de Reforma Urbana reivindicado pelo MTST parte de uma leitura comum ao FNRU e outros movimentos sociais, principalmente de moradia, que se configuraram a partir da redemocratização: de que a segregação e a desigualdade social são marcas constitutivas e características das cidades brasileiras e que transformá-las depende de uma luta que vá além daquela mais imediatamente centrada na pauta da moradia - representada, assim, pela bandeira de luta da Reforma Urbana. A luta pela moradia seria, neste sentido, impulsionadora de lutas sociais mais gerais, dentre as quais se insere a Reforma Urbana (GOULART, 2011a; MTST - CARTILHA DE PRINCÍPIOS, s/d; BOULOS, 2015a).

"O MTST não é um movimento de moradia, mas um movimento que, a partir da luta pela moradia, se organiza para $o$ enfrentamento das dificuldades que afetam as massas excluídas. Assim, nossos objetivos não são corporativos [...] a luta passa por este interesse mas não esgota-se nele." (PROGRAMA, s/p. apud GOULART, 2011b, p. 203)

Apesar dessa leitura comum, o projeto de Reforma Urbana formulado pelo MTST tem uma característica marcante: a presença do capital e a orientação de combatê-lo.

"O MTST se define como um movimento anticapitalista. Lutamos por moradia, reivindicamos a Reforma Urbana e pra nós não é possível Reforma Urbana Popular sem o enfrentamento com o capital. A luta pela moradia, é o imediato, mas lutamos por vida digna, e não há vida digna nas cidades segregadas, espoliadas pela dinâmica do lucro a todo custo. Por isso acreditamos que a luta pela moradia é parte da luta pela Reforma Urbana e também da luta de enfrentamento à lógica capitalista." (NÃO É POSSÍVEL..., 2015 - grifos nossos) 
No entendimento do MTST, o centro da luta pela Reforma Urbana necessariamente passa pelo enfrentamento ao capital, cujos interesses são defendidos e reproduzidos, inclusive, pelo Estado (MTST - CARTILHA DE PRINCÍPIOS, s/d) e se refletem nas cidades especialmente nos termos da especulação imobiliária. Assim, caberia ao movimento e à classe trabalhadora por ele mobilizada reivindicar uma nova forma de organização e produção da cidade, em que as marcas segregadoras resultantes das ações do capital sejam combatidas:

"É aqui que entra nossa proposta de uma Reforma Urbana. Defendemos uma transformação profunda no modo como as cidades estão organizadas. (...) Assim, a bandeira de uma Reforma Urbana profunda e popular torna-se uma luta fundamental contra os interesses do capital.

As cidades em que vivemos são divididas por grandes muros invisíveis. De um lado está a cidade dos ricos, com muito luxo, universidades, hospitais, onde tudo funciona bem. Lá só entramos pela porta dos fundos e pelo elevador de serviço. Do outro lado do muro estão as periferias, onde falta tudo. Aqui, o governo só aparece com a polícia para nos humilhar e reprimir. A nossa Reforma Urbana é derrubar estes muros." (MTST - CARTILHA DE PRINCÍPIOS, s/d, p. 04)

Ao que parece, o objetivo principal da proposta de Reforma Urbana formulada pelo MTST é o enfrentamento aos processos de especulação fundiária, para assim tornar as cidades menos desiguais e massacrantes à classe trabalhadora. A proposta de Reforma Urbana colocada pelo movimento parece, então, estar diretamente associada ao caráter anticapitalista e classista por ele reivindicado. 


\section{Um novo olhar para o Direito no MTST}

Feito o histórico e apresentadas as principais concepções políticas do MTST, nos atentaremos à sistematização dos principais usos do direito nos processos de lutas mais atuais do movimento.

Ressalta-se que, como já apresentado na introdução desta dissertação, grande parte do conteúdo ora sistematizado proveio do acompanhamento e participação na Brigada Jurídica de Apoio ao MTST, o que permitiu a abertura de um campo variado pois, a partir dela, foi possível acompanhar ocupações de terrenos, trancamentos, assembleias nas ocupações, formações políticas, debates específicos sobre o papel dos advogados no movimento e sobre a sua relação com a coordenação - e, ao mesmo tempo, munido do foco imprescindível à elaboração desta dissertação. Foi possível, assim, perceber o uso do direito em contexto mais amplo, enquanto prática do movimento.

A partir da observação dos espaços e debates do movimento, é possível apontar que o direito, longe de desempenhar um papel de aposta estratégica como o fez na Reforma Urbana, representa para o MTST, sobretudo, uma prática voltada ao apoio e defesa das ocupações de terrenos. Em outras palavras, a aposta estratégica do movimento centra-se nas ocupações e o direito aparece como uma prática que faz sentido na medida em que contribui diretamente para a realização de tal aposta. Seu caráter, neste sentido, é circunstacial à aposta estratégica das ocupações de terrenos.

Enquanto tal, o uso do direito é feito principalmente da seguinte forma: (i) ele é usado como uma das formas de defesa das ocupações; (ii) como um elemento discursivo do trabalho político do MTST nas ocupações; e (iii) como forma de aproximação do movimento com os acampados e com os moradores do entorno da ocupação.

Como uma das formas de defesa das ocupações, o direito é, no geral, acionado pelo MTST especialmente nos casos de ações judiciais de reintegração de posse dos terrenos onde fixa suas ocupações, nas quais configura como réu. De fato, já é esperado pelo movimento que, ao ocupar um terreno, alguns dias depois sobrevenha uma ação judicial demandando a reintegração de posse do terreno correspondente, já que a via judicial é um dos principais caminhos utilizados pelos proprietários na tentativa de reaver 
a posse do seu terreno. Assim, não são poucas as ações que o MTST precisa acompanhar e nas quais precisa se defender.

Vale ressaltar, também, que não é raro que, depois de consolidada a ocupação, esta seja alvo de abordagens feitas por particulares ou mesmo agentes do Estado que alegam terem recebido ordens para promover a desocupação do terreno. Tal alegação, mesmo infundada, pode gerar uma certa aflição entre os acampados, que sabem da violência física e psicológica que uma reintegração de posse pode gerar. Neste sentido, as coordenações das ocupações devem estar sempre informadas sobre a existência de processos judiciais que eventualmente possam decretar tais ordens, para assim poderem identificar a veracidade de tais ofensivas e tranquilizar os acampados. Por isso, há um intenso diálogo entre advogados e coordenadores de ocupação/acampados, para que estes sejam informados da existência da ação, seus termos, eventuais pedidos liminares, andamentos, etc.

Vale ressaltar que, apesar do MTST se utilizar de tal prática de defesa, ele entende que o embate judicial em si é muito limitado e dificilmente acarreta na garantia à permanência das suas ocupações. Entretanto, ignorar tal embate poderia se revelar muito prejudicial ao movimento, cujos acampados poderiam ser surpreendidos por uma ação reintegração de posse sem estarem preparados, por exemplo. Portanto, a utilização do direito como prática de defesa das ocupações na esfera judicial é normalmente realizada para que o movimento tenha ciência da disputa que está se desenrolando frente a cada ocupação; para tentar ganhar tempo de ação até que sobrevenha a reintegração de posse; e para, em alguns casos, ter acesso aos dados do proprietário, quando tal levantamento não tenha sido realizado previamente, de modo a viabilizar processos de negociação com ele e com o Poder Público. Porém, o movimento sabe das limitações inerentes a tal campo de atuação e, por isso, ressalta-se, ele é invariavelmente acompanhado por processos de lutas e mobilizações de rua lideradas pelo MTST, como forma de visibilizar o conflito instalado e de obter apoio político de diferentes sujeitos.

Para ilustrarmos isso, nos valemos da Ocupação Povo Sem Medo de Guarulhos, realizada em junho de 2017. Alguns dias após a entrada do MTST no terreno, tal ocupação se tornou uma das maiores já registradas pelo movimento, chegando à marca de 8.000 famílias. A ocupação foi largamente noticiada nos jornais locais, não só porque era a 
segunda ocupação realizada pelo MTST num curto intervalo de tempo na mesma região ${ }^{26}$, mas também porque contava com uma adesão enorme de acampados. Durante o processo de consolidação da ocupação - ou seja, durante as primeiras 48 horas - diversas abordagens policiais foram feitas, sugerindo a hipótese de desocupação imediata. Consolidada a ocupação, logo sobreveio uma ação judicial requerendo a reintegração de posse da área, mediante pedido liminar, a qual foi prontamente concedida pelo juiz. (ATO DA OCUPAÇÃO..., 2017; OCUPAÇÃO POVO..., 2017). Em meio a este processo, entretanto, o MTST foi percebendo a ofensiva que estava sendo orquestrada, e assim organizou uma série de mobilizações com as famílias acampadas, dentre as quais se destaca uma manifestação no centro da cidade de Guarulhos realizada em 09 de junho de 2017 composta de milhares de famílias. Tais manifestações foram tão intensas e mobilizaram uma quantidade de pessoas tão grande que tanto a Secretaria Municipal de Habitação quanto a Câmara Municipal se comprometeram com as demandas do movimento. Da parte da Secretaria Municipal de Habitação, esta se comprometeu a (i) intermediar os processos de negociação entre o proprietário do terreno e o movimento; (ii) requerer à Procuradoria do Município intervir no processo judicial e solicitar a realização de uma audiência de conciliação entre as partes e (iii) realizar estudos para a implementação de moradias populares que atendessem às demandas das famílias acampadas. Da parte dos vereadores, foi feita uma nota - redigida pelo Presidente e assinada por todos os 34 vereadores da Casa - que pedia uma solução negociada para o conflito e foi indicada a realização de estudos para viabilizar, caso possível, a demarcação da área como ZEIS. Somente após tais desdobramentos políticos, o MTST se colocou no embate judicial, no qual, além de argumentos jurídicos, apresentava todos os elementos políticos das suas manifestações. Assim, ao mobilizar o uso defensivo do direito após a conquista de apoio político significativo, o MTST garantiu uma inserção diferenciada no processo judicial, que rendeu-lhe muita força - a ponto de conseguir não só suspender a decisão de reintegração de posse mas, também, rumar em direção à viabilização do assentamento definitivo das famílias no terreno ocupado.

Tal exemplo é representativo de como o uso do direito enquanto prática defensiva é feito, invariavelmente, em conjunto com manifestações políticas do movimento, as

\footnotetext{
${ }^{26}$ Em abril de 2017, fora realizada a ocupação Hugo Chavez, também em Guarulhos (A NOVA..., 2017)
} 
quais, mais do que boas teses jurídicas, lhe garantem as condições de embate em sede judicial ${ }^{27}$.

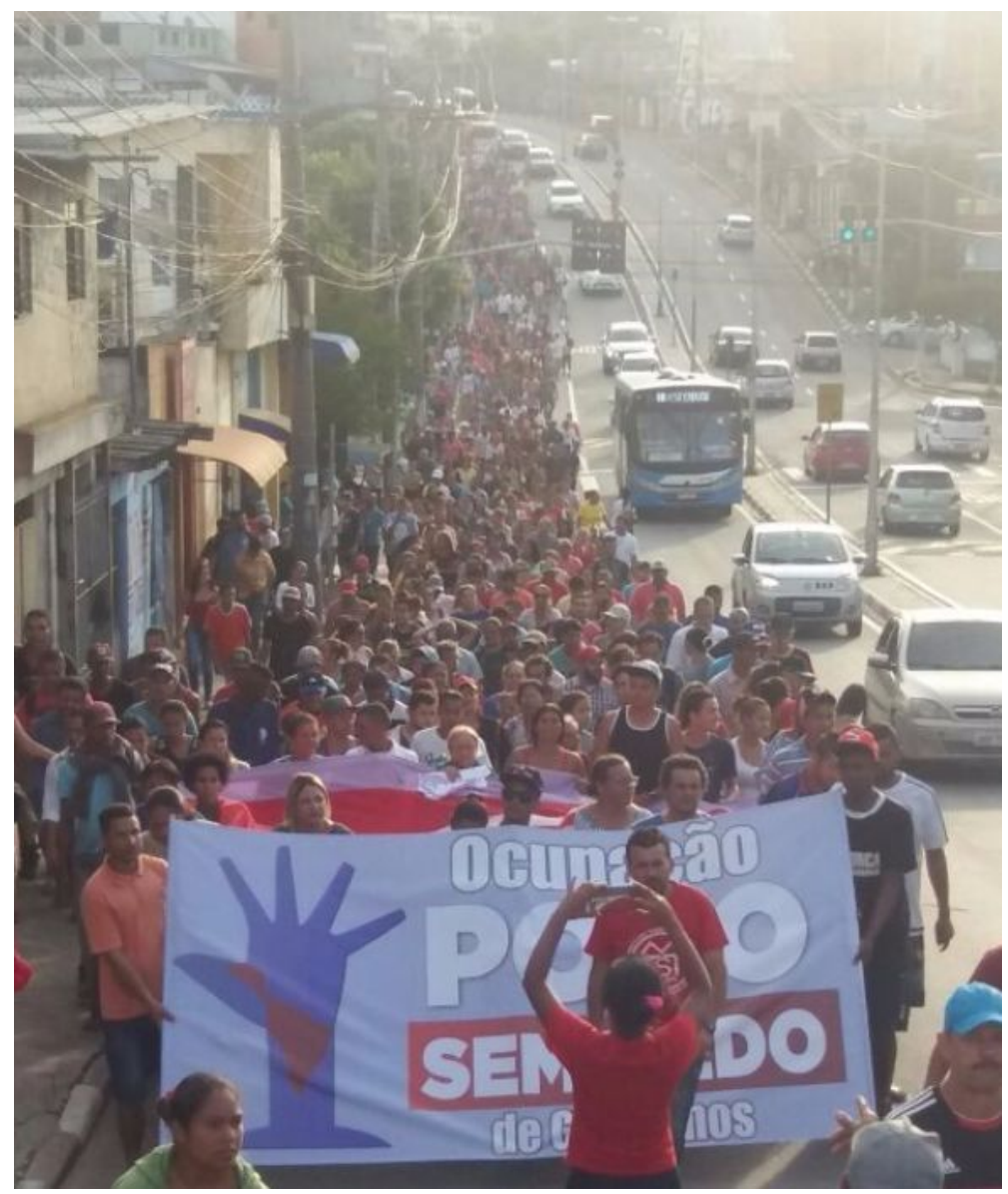

Manifestação realizada pelo MTST contra a ordem de reintegração de posse concedida em face da Ocupação Povo Sem Medo de Guarulhos. Fonte: Autos n. 1020373-52.2017.8.26.0224, da $2^{\text {a }}$ Vara Cível da Comarca de Guarulhos/SP. Autoria desconhecida

Vale dizer que o MTST o direito enquanto prática defensiva também é utilizado em outras ações cujo conteúdo se relacione diretamente ao movimento ou a seus integrantes (dentre coordenadores e acampados). Foi o caso, por exemplo, da atuação do movimento quando da prisão de 3 de seus militantes nas manifestações do dia 28 de abril de 2017, por entender que é uma tarefa política do movimento zelar pela segurança e pela defesa dos seus militantes (PRESOS POLÍTICOS..., 2017; JUSTIÇA MANDA..., 2017) ou mesmo da defesa do movimento, por meio do direito, contra representações e Inquéritos Civis nos quais configura como investigado. É o caso, por exemplo, do Inquérito Civil n. 188/2014,

\footnotetext{
${ }^{27}$ Vale a pena conferir tal embate nos Autos n. 1020373-52.2017.8.26.0224, da 2 ${ }^{\mathrm{a}}$ Vara Cível da Comarca de Guarulhos/SP.
} 
que tramita na Promotoria de Justiça de Habitação e Urbanismo, do Ministério Público do Estado de São Paulo (PROMOTORIA..., 2014), ou da Representação Civil feita em 2016 pelo Deputado José Carlos Aleluia, à época presidente do Democratas (DEM) da Bahia, à Procuradoria da República do Distrito Federal contra o coordenador Guilherme Boulos, por incitação ao crime (DEPUTADO..., 2016). Tais ocasiões são, entretanto, minoritárias; de fato, a prática defensiva do direito no MTST volta-se prioritariamente para a defesa das ocupações em sede judicial.

Outro uso do direito mobilizado pelo MTST é enquanto elemento discursivo, presente principalmente nas falas dos coordenadores direcionadas aos acampados no dia-a-dia das ocupações. Pelo fato da maioria dos acampados estar participando de processos de lutas organizadas por um movimento social pela primeira vez, não raro há, da parte deles, um certo receio quanto à legalidade e legitimidade das práticas do movimento, que podem ser consideradas muito radicais por alguns acampados. Não é raro ouvirmos acampados falarem que não concordavam com as ocupações, até que, diante de dificuldades geralmente de ordem econômica e social, tiveram que se render a elas. Por conta disso, ao chegarem nas ocupações, muitas famílias passam por um processo de desvelamento político do seu significado e do significado da própria atuação mais ampla do movimento. Em tais processos, esperados e compreendidos pelo MTST, é comum que o direito seja usado para legitimar as ações do movimento e contribuir para um processo de convencimento político das famílias, ainda mais diante da previsão legal de muitas das propostas apresentadas às famílias.

Neste sentido, é muito recorrente nos discursos predominantes nas ocupações a reiteração do direito à moradia, constitucionalmente garantido, mas não efetivado pelo Estado, e a obrigatoriedade do cumprimento da função social da propriedade, também constitucionalmente imposta e cujos instrumentos de efetivação ainda são pouco aplicados. Nesta linha de raciocínio, busca-se inverter o senso comum que taxa as famílias como invasoras, ao destacar o proprietário como um agente que burla as disposições constitucionais à espera de lucros e o Estado como um agente muitas vezes conivente às ações predatórias dos mercados. Os acampados, então, são apontadas como sujeitos sociais com direitos e fundamentais nos processos de denúncia e enfrentamento às lógicas do capital predominantes na cidades. Com isso, as ações dos acampados, organizados pelo movimento, são legitimadas e ganham novos contornos. 
"Juridicamente (...) tamo descumprindo a lei, tamo invadindo? Não!! (...) uma propriedade privada só pode (...) ser garantida pelo Estado com a força da polícia (...) se ela cumprir uma coisa muito importante que tá na Constituição, que é a função social (...) essa área aqui tá gravada no município (...) como ZEIS-2 (...) mas até agora, não foi feito nada. (...) Então o que estamos fazendo aqui, em primeiro lugar, é uma denúncia de uma área que não cumpre o seu dever legal (...) e depois, além de uma denúncia, uma pressão, para (...) implementar nessa área um projeto de habitação popular. O nosso movimento pressiona para que se cumpra a lei maior do nosso país." (FALA ADVOGADO do MTST na primeira assembléia da Ocupação Esperança Vermelha..., 2016.)

"(...) ao deixar as terras ociosas, os proprietários estão agindo de forma ilegal e criminosa. Deveriam ser punidos pela lei. Sabemos que isto não acontece porque o Judiciário (...) usa a velha máxima dos 'dois pesos, duas medidas'.

(...)

Ocupar não é crime, é um direito. Os trabalhadores sem-teto que ocupam estão exigindo o cumprimento da função social da propriedade e reivindicando legitimamente o direito à moradia digna, também prevista na Constituição". (BOULOS, 2015a, p. 81).

Nas primeiras vezes em que constatou-se tal uso, nos lembramos da crença no direito que, desde os processos políticos da Vila Itororó foi observado. Porém, ao longo da observação e interação com o movimento, verificou-se que tal referência ao direito tem um caráter mais pedagógico no processo de politização dos acampados e legitimador das ações do movimento. A contradição entre, de um lado, o direito positivado na Constituição Federal e demais normas urbanísticas e, de outro, sua parca efetivação (quando não, negação), é colocado pelo MTST de maneira a incentivar a movimentação 
das famílias no sentido de tentar efetivá-los concretamente, quase que na "marra", ainda que no território específico das ocupações.

Por fim, um uso do direito que também reflete a sua posição como prática de apoio às ocupações no sentido da construção desses espaços como referência aos acampados e aos moradores do entorno da ocupação são os mutirões de atendimento jurídico. Neles, são realizadas conversas informais com os acampados, nas quais geralmente são indicadas os possíveis espaços - que vão desde instituições públicas como a Defensoria Pública do Estado de São Paulo ou o Juizado Especial Cívil até ONGs, Centros de Referência e Centros de Direitos Humanos - nos quais as questões levantadas podem ser devidamente resolvidas ou acompanhadas. Assim, por ser um trabalho prioritariamente de indicação de serviços legais e sociais existentes, este é um trabalho que pressupõe um levantamento destes, dando preferência, inclusive, àqueles localizados nas proximidades da ocupação.

A sistemática dos mutirões de atendimento normalmente é muito simples: é marcado um dia em que os técnicos ficam na ocupação à disposição dos acampados e dos moradores do entorno; não tarda até que eles comecem a chegar, de início mais tímidos, e depois mais descontraídos. E, na medida em que as conversas vão ficando mais cheias, é possível perceber que elas representam, muitas vezes, uma porta de entrada para os moradores do entorno que ainda não tinham visitado a ocupação. Neste sentido, os mutirões de atendimento jurídico perfazem uma prática de aproximação dos acampados e dos moradores do entorno com a dinâmica da ocupação e auxiliam no processo de consolidação das ocupações como espaços de referência do movimento.

Antes da entrada no campo, imaginávamos nos deparar, dentre as práticas do MTST, também com um uso do direito orientado à disputa legislativa e marcos normativos gerais da política urbana, ainda que já desconfiasse que tal uso não desempenhasse uma posição estratégica prioritária do movimento, como foi feito pelo MNRU no período anterior. Tal imaginário advinha de uma observação distanciada da chamada "Batalha do Plano Diretor" - uma das grandes ações do MTST em 2014, que envolveu manifestações, trancamentos e uma vigília de sete dias em frente à Câmara 
Municipal de São Paulo durante os dias imediatamente anteriores à aprovação do Plano Diretor Estratégico (PDE).

Se, por um lado, assistíamos grandes manifestações populares que mobilizavam milhares de pessoas nas ruas e mais dezenas delas acampadas em frente à Câmara Municipal em um processo de pressão frente à oposição parlamentar que tentava protelar a aprovação do PDE, por outro, parecíamos nos deparar com mais um exemplo de mobilização voltada à aprovação legislativa que, apesar de apresentar avanços importantes no que tange à habitação no Município de São Paulo (como a regulamentação de instrumentos urbanísticos como a ZEIS e a cota de solidariedade, o aumento expressivo de imóveis demarcados como ZEIS e a instituição de regras para o Parcelamento, Edificação ou Utilização Compulsórios (PEUC), etc.), remontava à estratégia adotada pelos movimentos da Reforma Urbana desde meados da década de 80.

Entretanto, durante o processo de pesquisa de campo, ficou claro que a demanda do MTST, naquele momento, não era a aprovação do Plano Diretor Estratégico em si, a partir da crença simbólica de que ele poderia garantir novos rumos ao desenvolvimento urbano de São Paulo, e sim de alguns de seus dispositivos, os quais implicavam benefícios concretos e certeiros para as lutas em ocupações específicas localizadas no Município. A luta pela aprovação do Plano Diretor, então, reiterava o uso do direito no apoio das ocupações do movimento.

Para compreendermos melhor isso é preciso, primeiramente, entender que a "Batalha do Plano Diretor" foi resultante de um processo de lutas organizado pelo movimento. Desde a consolidação da Ocupação Nova Palestina no final de 2013, o MTST começou a travar uma série de manifestações, atos e articulações políticas a fim de garantir que, naquele mesmo terreno onde a ocupação se encontrava, fossem construídas as unidades habitacionais voltadas ao atendimento da demanda das famílias acampadas. O que impedia tal construção, na época, era o fato de a gigantesca área de 1 milhão de metros quadrados no M'Boi Mirim estar demarcada como Zona de Proteção e Desenvolvimento Sustentável (ZPDS), a qual, segundo as normas da Lei Municipal 13.885/2004, tinha parâmetros restritos de ocupação e uso do solo. Ademais, desde 2010, havia um Decreto Municipal que determinava que tal área deveria ser destinada à implantação de um Parque Municipal, já que no terreno havia uma grande porção de vegetação significativa. 
O terreno parecia, então, completamente inacessível à recepção das demandas do movimento - o que não impediu sua ocupação por milhares de pessoas, chegando ao número de 8.000 famílias (OCUPAÇÃO NOVA PALESTINA..., 2014). Neste sentido, considerando que um dos pontos fulcrais de discussão do Plano Diretor Estratégico era o mapeamento e sistematização dos Parques Municipais Existentes e Propostos - que culminou no Quadro 07 anexo à lei - e também a regulamentação e demarcação das Zonas Especiais de Interesse Social (ZEIS), foi avaliado pelo movimento que o processo de revisão do PDE poderia abrir uma brecha de ação: pois, se, de fato, as circunstâncias legais que até então envolviam a área não fossem mudadas, a concretização da demanda do movimento estava fadada ao fracasso.

Neste mesmo contexto, em maio de 2014, o MTST realizou a Ocupação Copa do Povo, em um terreno localizado a menos de 4 quilômetros da Arena Corinthians, na Zona Leste, na qual a construção de habitações de interesse social não era impossível, mas restrita mais uma vez por conta do zoneamento imposto pela Lei Municipal 13.885/2004. (OCUPAÇÃO PERTO DO ITAQUERÃO..., 2014). A perspectiva de mudança do zoneamento da área para ZEIS - uma zona caracterizada, além da destinação de uso prioritário à Habitações de Interesse Social, por parâmetros de ocupação bastante permissivos em comparação com as demais zonas - implicava em permitir um potencial de ocupação mais alto para o terreno. Seguindo então a mesma lógica pensada para a Ocupação Nova Palestina, o MTST passou a entender que uma mudança concreta no zoneamento da área por meio da legislação poderia garantir parâmetros mais permissivos que, traduzidos em termos construtivos, gerariam um aumento na quantidade de famílias cujas situações de precariedade habitacional poderiam ser revertidas.

Neste sentido, o que estava sendo reivindicado nas ações do movimento não era o PDE enquanto marco legislativo mais importante da política urbana municipal ou a ZEIS enquanto instrumento jurídico urbanístico, mas, especificamente, a demarcação de ZEIS nos terrenos onde se situavam as ocupações da Vila Nova Palestina, da Copa do Povo, e também da Faixa de Gaza, Capadócia e Dona Déda (PLANO DIRETOR..., 2014), justamente porque tais demarcações teriam o condão de potencializar o processo de negociação dos terrenos e contratação dos recursos do Programa Minha Casa Minha Vida (PMCMV), e, consequentemente, a conquista real da moradia para milhares de famílias organizadas pelo movimento - o que de fato aconteceu, já que as 2 mil unidades habitacionais 
da Nova Palestina já estão percorrendo os últimos trâmites do processo de licenciamento na Prefeitura Municipal de São Paulo e as 2 mil unidades da Copa do Povo também já estão em fase de negociação. Sem entrarmos no mérito sobre a qualidade e sentido das habitações produzidas pelo PMCMV, ressaltamos, então, que o direito neste contexto estava sendo usado em razão de implicações concretas que beneficiariam diretamente o movimento, a partir da potencialização dos ganhos em termos de moradia para os seus acampados.

O movimento, então, foi às ruas demandar as demarcações das áreas e começou a desenhar os processos políticos que viriam constituir a "Batalha do Plano Diretor". Tamanha foi a intensidade da agenda de manifestações do MTST em São Paulo, durante o final de 2013 e início de 2014, que o movimento conseguiu que a Prefeitura se comprometesse a suspender a reintegração de posse da Ocupação Dona Déda (pois localizada em terreno Municipal no Campo Limpo) e revogar o já citado Decreto Municipal que transformava a área em que está localizada a Ocupação Nova Palestina em parque. Em contrapartida, entretanto, o então Prefeito Fernando Haddad fez um singelo pedido: que o MTST garantisse nada mais nada menos que a votação do Plano Diretor Estratégico na Câmara Municipal (HADDAD DIZ..., 2014; HADDAD ALTERA..., 2014) - o que foi prontamente feito meses depois, por meio das manifestações que caracterizaram a chamada "Batalha do Plano Diretor".

Isso é importante salientar pois, para quem estava de fora do movimento, a " $\mathrm{A}$ Batalha do Plano Diretor" poderia realmente ser compreendida como mais uma manifestação em torno de um marco legislativo, talvez excessivamente recorrente como estratégia de lutas durante a Reforma Urbana, como vimos no capítulo o1. Porém, o MTST sabia exatamente o que estava em jogo na aprovação do PDE nos termos do Substitutivo apresentado pela Câmara Municipal de São Paulo. Para se ter uma ideia, antes mesmo da aprovação do PDE, em 2014, os terrenos da Nova Palestina e da Copa do Povo já tinham sido objeto de negociação com os entes federativos e com os proprietários e já haviam sido firmados os respectivos acordos de compra e venda para a posterior produção de Habitações de Interesse Social pelo PMCMV; entretanto, o MTST sabia não só que as condições das negociações poderiam variar de acordo com a conjuntura política, mas também que a mudança de zoneamento das áreas potencializaria a construção de unidades habitacionais e garantiria uma resposta ainda mais adequada à demanda do 
movimento $^{28}$, de maneira que a continuidade das manifestações e pressões políticas foi fundamental para manter o clima político aceso e angariar benefícios para o atendimento das famílias acampadas.

Neste sentido, a "Batalha pelo Plano Diretor" travada pelo MTST foi uma ação resultante de um processo político intenso do qual o movimento e as famílias por ele organizadas foram os protagonistas e que, apesar de aparentar ter relação intrínseca com a legislação em si, representava uma batalha para a obtenção de conquistas concretas relacionadas à transformação das ocupações em moradias populares. Pode-se até dizer que o movimento evocou o direito em um sentido propositivo, porém direcionado especificamente a conquistas e avanços nas ocupações de terrenos.

Feita a sistematização dos usos dados ao direito nas lutas travadas pelo MTST, podemos apontar que o movimento não inclui o direito, como estava sendo feito nos anos anteriores no âmbito das lutas urbanas, enquanto estratégia prioritária para a realização de justiça social e urbana, ao ressignificá-lo e não evocá-lo nem enquanto marco de cidadania nem como uma conquista em si ao ser positivado.

O Direito parece ser identificado pelo MTST como um dado da realidade que precisa ser considerado e utilizado quando adequado, porém não é entendido como um dado primordial que deve ser mobilizado de maneira isolada dentro do espectro das lutas. Por isso, ele é invariavelmente utilizado como prática, conjuntamente com outras ações, cujos objetivos se direcionam ao apoio das ocupações do MTST, essas sim estratégias prioritárias do movimento. Assim, ele não é entendido como um fator limitador ou conformador de suas práticas, apesar do movimento entender que ele pode tanto trazer benefícios e facilitar os caminhos em direção à efetivação das suas reivindicações quanto gerar consequências jurídicas e institucionais problemáticas.

\footnotetext{
${ }^{28}$ No caso da ocupação Nova Palestina, a área localizada no cruzamento entre a Rua Clamecy e Estrada do M'Boi Mirim, na zona sul de São Paulo, estava demarcada como Zona de Proteção e Desenvolvimento Sustentável pela Lei Municipal no 13.885/2004 e, em razão disso, não permitia a construção de moradias de interesse social nos termos da demanda apresentada pelo MTST, pois reduziria o potencial construtivo a apenas $10 \%$ do terreno. Diante disso, o movimento reivindicou sua demarcação enquanto ZEIS, pois seus parâmetros de uso e ocupação garantiriam a construção de uma maior oferta de habitaçóes de interesse social;
} 
A atuação jurídica é, portanto, circunstancial, na medida em que, não raro, ajuda o movimento a ganhar tempo em processos judiciais, a selar acordos com os proprietários e com as instâncias de governo, a minimizar pontualmente os processos de criminalização e violência que o movimento sofre nas ações do Estado, entre outros

A atuação do MTST, neste sentido, foca-se nas ocupações e nos caminhos necessários para garantir seu sucesso e a consequente conquista da moradia para os acampados. Se, neste processo, for importante um embate judicial ou necessária a aprovação de alguma lei ou decreto, isso é reivindicado sempre tendo em vista a conquista real do atendimento habitacional.

Destacamos, no entanto, que tal entendimento não parece ter sido elaborado pelo MTST de maneira descontextualizada. Novamente, o fato de o movimento ter sido criado no final da década de 90 promoveu o seu afastamento dos processos históricos e políticos, principalmente desenvolvidos durante a década de 80 , nos quais o direito adquiriu um significado estratégico nas lutas populares. Pelo contrário, o MTST nasceu nos duros anos do Governo FHC, no qual as medidas neoliberais estavam em alta e as contradições entre o texto constitucional e as políticas de governo - e, no limite, entre o direito positivado e o direito efetivado - ficavam cada vez mais evidentes.

Outra chave explicativa que parece interessante ressaltar é o fato de o MTST ter absorvido alguns dos princípios e aprendizados do MST, em razão da sua história e criação já retratadas nesta dissertação. E a luta pela reforma agrária liderada pelo MST não parece incluir em suas estratégias, mesmo durante os anos 80 e 90, a formulação de um ordenamento jurídico específico e legislações mais progressistas com a expectativa de uma melhoria qualitativa das condições de vida e acesso mais democrático à terra rural ${ }^{29}$. Assim como o MST, o MTST parece focar, desde sua criação, na organização de ocupações de terra como estratégia primordial tanto de organização massiva da base social, de pressão por construção de moradias, de democratização do espaço e de denúncia de ilegalidades e injustiças. A ocupação é, neste sentido, essência de ambos os movimentos e orienta suas ações para um lócus diferente das disputas legislativas. Vale, neste sentido, ressaltar uma fala do João Pedro Stédile, uma das grandes lideranças do MST, em entrevista à Revista Brava Gente:

\footnotetext{
${ }^{29}$ Essa é, inclusive, uma questão que merece ser trabalhada em separado: como que a luta da Reforma Urbana e a da Reforma Agrária tomaram rumos tão diferentes no sentido da aposta legislativa.
} 
"(...) a nossa luta pela terra e pela reforma agrária - já havíamos descoberto por nós mesmos - só avançará se houver luta de massas. Se nos contentarmos com uma organização fechada, sem poder de mobilização, ou se ficarmos de conchavos com o governo ou esperando pelos nossos direitos, só porque eles estão descritos na lei, não conquistaremos absolutamente nada. O direito assegurado na lei não garante nenhuma conquista para o povo. Ele só é atendido quando há pressão popular. (...) Ela [a burguesia] procura neutralizar nossa força com a cooptação, entregando-nos algumas migalhas ou paparicando líderes vaidosos, personalistas ou ideologicamente fracos. O povo só conseguirá obter conquistas se fizer luta de massas. $E$ isso que altera a correlação de forças políticas na sociedade. (...) Um problema social só se resolve com luta social. Ele está inserido na luta de uma classe contra a outra" (STÉDILE e FERNANDES, 1999, p. 45)

Assim, fruto desses contextos políticos e sociais, foi possível ao MTST ressignificar os usos do direito nos processos de lutas urbanas, de modo a articulá-los como uma prática coerente dentro de um processo mais amplo de lutas e para negá-los como estratégia descolada das ações diretas das ocupações de terrenos urbanos - essas sim representantes da estratégia prioritária do MTST, como já apontado. Vejamos os sentidos disso no capítulo seguinte. 


\section{capítulo 4. os caminhos da Reforma Urbana: conclusões e apontamentos}

Como vimos ao longo desta dissertação, a Reforma Urbana é evocada como uma bandeira de luta por movimentos sociais urbanos desde 1988 (ainda que em 1963 tenha sido primeiramente aventada) até os dias atuais. Entretanto, seus sentidos parecem mudar ao longo dos anos e, neste capítulo, faremos um esforço de iluminar os recentes rumos atribuídos a tal bandeira de luta na proposta política do MTST, que envolve um outro entendimento do potencial do direito nos processos de lutas sociais.

A partir da análise dos nossos estudos, parece possível dizer que, no histórico de lutas da Reforma Urbana, há momentos em que o direito é mobilizado de maneira diferente, que acabam por coincidir com ciclos políticos e de lutas urbanas, já mencionados por Maricato (2015) e Arantes (2013).

Há, então, um primeiro momento de uso e mobilização do direito no campo jurídico-institucional enquanto um elemento de cidadania e realizador de processos de justiça social e urbana, que acaba se desenrolando em práticas que vinculavam diretamente o direito e a legislação. Este primeiro momento é característico das lutas pela Reforma Urbana vivenciadas entre 1988 e meados da década de 2010, quando os movimentos sociais aglutinados em torno do MNRU propagaram, por meio de suas práticas, um ideal de Reforma Urbana cujos sentidos de justiça estavam ligados com o direito e, mais intensamente, com as legislações. 
Este primeiro momento se orientava por um projeto político, formulado a partir das lutas pela redemocratização nos anos 1980, que reivindicava fortemente a noção de cidadania e creditava um papel central ao Estado na sua realização mediante a instituição e efetivação dos direitos urbanos. Neste projeto, a noção de cidadania concedia à bandeira de luta da Reforma Urbana um caráter progressista na medida em que traduzia, ao mesmo tempo, um reconhecimento por parte do Estado de sujeitos sociais antes tratados como "de quinta categoria" e uma legitimidade de tais sujeitos na reivindicação e construção do novo Estado Democrático de Direito. Neste sentido, o ideal de cidadania parecia munido de grande potencial para a criação de uma identidade coletiva que abarcasse diferentes grupos sociais e políticos em torno da bandeira da Reforma Urbana, necessário à época. Eram todos cidadãos, cujas vozes deveriam ser ouvidas.

Entretanto, essa noção de cidadania, criada nos marcos das lutas burguesas, encobre o fato de que, atrás da igualdade jurídica formal, há todo um sistema real de desigualdade de classes que constitui 'catracas invisíveis' à realização plena da igualdade instituída. Fazer parte da categoria de 'cidadão' parecia igualar todos os membros da sociedade, porém as marcas reais de gênero, raça e classe continuavam a ser fatores estruturantes de desigualdade social. A ideia de cidadão, dessa forma, acaba por acarretar em um esvaziamento de sentido da categoria de classe como elemento identitário das camadas populares, para substituí-lo por um elemento amplo que ideologicamente serviria para encobrir as tensões e conflitos entre as classes sociais.

"A cidadania é, portanto, mistificadora em cada um de seus aspectos. De modo geral, ela desempenha uma função política e ideológica conservadora. A ilusão de igualdade que ela pode produzir, e que geralmente produz, dissolve, aos olhos dos trabalhadores, a ideia do pertencimento de classe. (...) a cidadania individualiza os agentes da produção, dissolvendo, no plano ideológico, a realidade das classes e da luta de classes. Percebendo-se como cidadãos, os trabalhadores deixam de se perceber como classe social." (BOITO JUNIOR, 2007, p. 258) 
E, mesmo com o posterior desenvolvimento da noção de cidadania burguesa em razão da ampliação dos direitos civis e da instituição dos direitos políticos e sociais, o papel ideológico da cidadania se manteve, visto que, dentro dos limites do Estado burguês, nunca seria possível a superação da divisão social de classes e consequente queda das já referidas 'catracas invisíveis' pelos trabalhadores.

Então, mesmo com a ascensão dos governos petistas e a ampliação considerável dos direitos sociais mediante políticas de distribuição de renda, as desigualdades estruturantes, dentre elas, a classe, continuaram a ser propagadas, reiteradas e - porque não - reiventadas a partir de uma disseminação de um ódio de classe crescente à medida em que uma nova classe média se consolidava (BOITO JUNIOR, 2007).

Ainda assim, a noção de cidadania continuou fortemente veiculada no imaginário e no senso comum popular como um horizonte a ser atingido...ser cidadão é ser parte, é ser reconhecido, é ser legitimador de algo e as camadas populares, que viviam às margens numa sociedade excludente, ansiavam por fazer parte disso. Tal noção foi fortemente evocada nas lutas políticas durante todo o século XX, inclusive naquelas iniciada nos anos 80 e que se estenderam até meados de 2010 pela Reforma Urbana no Brasil e, neste sentido, foi marcante neste primeiro momento.

Tais lutas, ao evocar a noção de cidadania, traçam uma relação intensa com o Estado, visto que a referida noção só faz sentido se mediada pela figura de um Estado Nacional, que garante, através de diferentes ações e instrumentos, a sua realização. Disso resultou uma leitura que colocava o Estado em uma posição central na garantia dos direitos dos seus cidadãos e que aliou-se, também, à ideia do Estado como principal agente planejador e interventor das cidades brasileiras (TANAKA, 2017). Assim, consolidou-se uma tendência estratégica entre os movimentos sociais ligados à bandeira da Reforma Urbana no sentido de centrar suas lutas no Estado a partir de estratégias que privilegiavam a ação no campo jurídico-institucional, e conferir pouco destaque a outras forças sociais.

Neste sentido, o papel estratégico que o direito, a partir do campo jurídico-institucional, foi ganhando no Ciclo da Reforma Urbana tem um caráter também conjuntural, pois concebido a partir de leituras de realidade e projetos políticos formulados por tais movimentos em um momento político específico. 
Assim, entendendo a aposta nas lutas no campo jurídico-institucional como uma prática que também provém de uma conjuntura, torna-se mais possível abordar os termos de tal aposta de maneira a afastar um olhar que a entenda como um mero erro infundado ou um produto do desconhecimento ou confusão dos movimentos sociais ligados à Reforma Urbana. Tal olhar parece ser absolutamente leviano, na medida em que parece destacar os movimentos como ingênuos ou desqualificados no cenário político e, invariavelmente, despreza a importância que as lutas travadas por eles tiveram ao longo dos anos e das quais muitos movimentos - inclusive o MTST, aqui estudado - são herdeiros diretos.

De fato, durante um período deste primeiro ciclo, as estratégias e práticas dos movimentos ligados à Reforma Urbana reverberaram em avanços importantes, a começar pela própria conquista de retomada da bandeira da Reforma Urbana, após o seu enterro e cooptação pelos militares durante o período ditatorial pós 1964 (MARICATO, 2014); além disso, as próprias legislações avançavam em pontos importantes da política urbana e os espaços institucionais renderam importantes debates, principalmente no seio dos primeiros anos de exercício do Ministério das Cidades, antes de se tornarem espaços potenciais de cooptação e abrandamento dos movimentos sociais urbanos.

O que talvez tenha se perdido de vista, ao longo do período da Reforma Urbana, é que o Estado brasileiro, em uma sociedade notadamente patrimonialista e desigual, pode exercer um poder de cooptação e uma relação promíscua com os interesses particulares (MARICATO, 2014) e que, por isso, precisa ser sempre objeto de avaliação e atenção dos movimento no cenário de lutas. Ao que parece, os movimentos ligados a esse ciclo tiveram dificuldade de localizar isso melhor na sua leitura de realidade, ainda mais quando o governo federal passou a ser liderado por um partido tanto no sentido de avaliação constante do Estado quanto de percepção e localização do mercado no cenário urbano.

Isso foi se evidenciando com os novos rumos dos arranjos produtivos e econômicos nas cidades brasileiras, desenvolvidos especialmente a partir dos anos 2000 . Os mercados ganharam as cidades de assalto e abocanharam territórios inteiros onde, com algumas restrições fixadas e com muitos tratos de conivência do Estado, demolem, despejam, constroem, vendem e privatizam (FIX, 2001; MARICATO, 2014; MARICATO, 2015). O avanço dos mercados imobiliários e financeiros sobre as cidades fez com que novos atores fossem incluídos no jogo do urbano e os velhos atores, reposicionados ou 
mesmo jogados para escanteio. O Estado passou a aparentar ser cada vez mais incapaz ou "desmotivado" a intervir em defesa do interesse público e social nas cidades, ao passo que processos escusos de corrupção, compra de processos de licitações e acordos políticos nefastos se multiplicaram, deixando as cidades à mercê dos interesses econômicos e indicando que, se até aquele momento os movimentos sociais não tinham ainda ressignificado suas práticas políticas, outros atores já uniam forças para ampliar e ressignificar suas estratégias mais arcaicas.

Ainda assim, diante desses novos arranjos, houve uma insistência, por parte dos movimentos sociais, na leitura de realidade que evocava as noções de cidadania e de centralidade do Estado na condução da questão urbana - e a aposta no campo jurídico-institucional parece ser a melhor expressão disso.

Entretanto, tal insistência não pode perdurar por muito tempo. A situação de precariedade das cidades brasileiras e a perda de ofensividade dos movimentos em torno da Reforma Urbana já indicavam, nos anos finais da década de 2000, a necessidade de reinvenção das lutas urbanas, inclusive daquelas focadas na bandeira de luta da Reforma Urbana.

Assim, em 2013, há uma explosão, uma intensa ruptura com os rumos das lutas urbanas travadas até então. Muitas perguntas sobrevieram aos processos políticos iniciados em 2013, mas, ao mesmo tempo, algumas certezas se iluminaram, como, por exemplo, a avaliação de que as práticas dos movimentos sociais ligados à Reforma Urbana já tinham se esgotado e que a aposta no campo jurídico-institucional realmente configurava um erro estratégico. No limite, uma das questões que ficou evidenciada em 2013 foi a limitação dos processos políticos protagonizados pelo Estado, que mesmo conduzido por um partido político aberto às demandas populares e promovedor de políticas importantes para a classe trabalhadora, não rompeu com os desmandos da classe dominante e dos mercados na produção das nossas cidades.

Assim, a partir de 2013, inaugura-se um novo momento político das lutas urbanas (MARICATO, 2015; ARANTES, 2013), que também reivindicava a luta pela Reforma Urbana (MARICATO, 2015), porém a partir de novas concepções políticas, diferentes daquelas propagadas pelos movimentos de orientação democrático-popular hegemônicos no período anterior. Dessa forma, diante da já referida certeza do erro estratégico que a aposta no campo jurídico-institucional representou, o novo ciclo parte de uma postura 
crítica às lutas institucionalizadas e propõe, de imediato nas ruas, sua rejeição - e, ao longo dos acontecimentos, sua ponderação.

"Não se trata de ignorar a luta por espaços institucionais por via eleitoral ou qualquer outra via, mas de dar a ela a devida dimensão no processo de construção de um outro mundo marcado por outras relações sociais" (MARICATO, 2014, p. 99)

"A cidade é uma só. Aprendemos com o ciclo anterior os limites da luta institucional. Saberemos usá-la quando necessário, mas com as últimas jornadas vimos que as conquistas podem se dar de outro modo - inesperado e radical." (ARANTES, 2017).

Neste contexto de um novo ciclo político, o MTST aparece como força social impulsionadora de novas práticas. Mais uma vez, ressaltamos que o movimento já era atuante e consolidado no cenário das lutas urbanas desde antes de 2013, porém a partir desse ano ele se reposiciona no cenário político e, com base em sua leitura de realidade, dá novos significado às estratégias políticas nas lutas urbanas.

Neste sentido, é fundamental reiterar que o MTST não inventou nenhuma estratégia ou prática absolutamente nova no processo mais recente de luta pela Reforma Urbana; o uso do direito como prática defensiva, as ocupações de terrenos, já eram práticas conhecidas e realizadas pelos movimentos sociais atuantes. Longe de 'reinventar a roda', o MTST consegue, a partir do seu projeto e práticas políticas, imprimir novos significados a estratégias já há muito conhecidas pelos movimentos de moradia e muní-las de potencialidades interessantes.

No que tange à Reforma Urbana, parece haver um caráter de continuidade neste novo ciclo, pois permanece sendo considerada uma bandeira de luta importante a ser perseguida nas lutas urbanas. Porém, o foco do projeto político da Reforma Urbana reivindicada pelo MTST é diferente na medida em que, ao partir das concepções anticapitalistas e classistas, não centraliza a cidadania, efetivada a partir da realização dos direitos urbanos, como seu horizonte político de justiça social e urbana e reposiciona o campo jurídico-institucional e a elaboração de legislações em outro sentido. Diferente 
disso, sua proposta de Reforma Urbana foca no enfrentamento feito a partir da luta direta massificada contra os interesses do capital - que se desdobram tanto nos interesses especulativos dos mercados quanto na ausência de prioridade de investimentos públicos em infra-estrutura e serviços urbanos.

O horizonte político da cidadania parece, então, superado nas práticas e discursos do MTST (GOULART, 2011a). Isso de forma alguma quer dizer que principalmente os acampados não recorram à cidadania como critério legitimador das suas demandas ou mesmo deixem de mencionar a obrigação do Estado de efetivar os direitos urbanos e sociais, como pudemos apurar no trabalho de campo; estranho seria se eles não agissem assim, visto que há, como já mencionado, a consolidação da noção de cidadania como catalisadora de práticas e reivindicações responsáveis ou mesmo conservadoras provenientes das ações do 'cidadão de bem'. Entretanto, o MTST enquanto organização política não reivindica a cidadania nestes marcos.

Notamos, então, uma grande diferença na leitura política do MTST da Reforma Urbana, em razão das orientações do seu projeto e da sua prática política. Para o movimento, a noção de cidadania não se encontra em seu horizonte político e nem é ponto de partida para a sua leitura de realidade (GOULART, 2011a). Pelo contrário, ao reivindicar claramente um projeto classista e anticapitalista de luta política e orientar suas ações em vista de tais concepções, o movimento consegue formular uma leitura política que ao mesmo tempo rechaça a noção de cidadania como orientadora da Reforma Urbana (e das lutas em geral) e reforça sua identidade política em torno da classe trabalhadora e dos seus interesses.

É preciso ressaltar que tais concepções e leituras feitas pelo MTST parecem ser fruto de sua história e dos seus acúmulos políticos, muito mais do que uma habilidade ou capacidade política inerente. A começar pelo fato do MTST não ter vivido, enquanto movimento político, as lutas pela Reforma Urbana da década de 80, de maneira a desfrutar de um distanciamento analítico e mesmo afetivo daquele momento histórico. Ainda que o MTST tenha militantes históricos que viveram tal época a partir da sua militância em outros movimentos ou partidos, a maioria da sua coordenação é atualmente formada por militantes forjados em outros processos políticos, inclusive mais recentes. Ao contrário, mesmo hoje, alguns movimentos do ciclo anterior têm muitas lideranças que foram forjadas no processos de lutas da constituinte e da democratização, 
o que muitas vezes significa um apego às orientações políticas e formas de lutas elaboradas naquele momento. O MTST, contudo, foi criado nos finais da década de 90 , quando a promessa de cidadania anunciada pelas lutas da década de 80 e reafirmada pela Constituição já tinha perdido grande parte da sua força.

Ademais, mesmo a mudança da base social organizada pelo MTST parece ser um fator importante de ser mencionado, no que tange à questão da luta pela cidadania. Pois se no ciclo da Reforma Urbana a base dos movimentos sociais era formada por trabalhadores que estavam sendo incorporados pelas fábricas, atualmente a base social do MTST é formada por trabalhadores que estão sofrendo com o processo de precarização das condições de vida e de trabalho, inclusive com o aumento do desemprego e dos custos das condições de reprodução (GOULART, 2011a). Muitos destes trabalhadores já foram contemplados por um momento de relativa ampliação da cidadania, a partir da implementação dos programas de assistência dos Governos Lula e Dilma, porém mesmo assim viram suas condições de vida piorarem em razão dos processos econômicos mais amplos. A essa massa de trabalhadores, não bastou uma ampliação relativa de direitos sem uma transformação minimamente radical das condições estruturais da nossa sociedade; ficou claro, neste sentido, as limitações da noção de cidadania e mesmo da atuação do Estado. O fortalecimento das concepções anticapitalista e classista do MTST (e de outros movimentos sociais) sobrevém também dessa conjuntura política.

Por fim, vale dizer que o momento atual do país dificulta a manutenção de uma noção como a de cidadania nos processos de lutas sociais. Sendo a cidadania um atributo que se dá mediante o Estado e estando o Estado Brasileiro em um momento de grave crise política e institucional, realmente parece uma tarefa árdua a de mobilizar lutas populares direcionadas a partir desta noção. Na atual conjuntura, então, falar em cidadania talvez seja apostar em um elemento identitário que não representa mais os anseios da população mais pobre. Neste sentido, a reivindicação do elemento de classe parece ter mais capacidade de mobilizar os trabalhadores, em razão das condições precárias de vida que eles normalmente (e infelizmente) compartilham.

Assim, ao distanciar os processos de luta política pela Reforma Urbana de uma noção de cidadania e ao deslocá-los em direção às lutas diretas baseadas em concepções anticapitalista e classistas, o MTST consegue imprimir um caráter diferente às lutas e assim organizar a sua base a partir de um novo discurso e mesmo novas estratégias. $\mathrm{O}$ 
Estado, que antes era visto não só como realizador da cidadania a partir da elaboração de direitos urbanos mas também como principal agente planejador e interventor das cidades brasileiras, era entendido como agente central das reivindicações dos movimentos do Ciclo anterior; para o MTST, entretanto, o Estado representa mais um agente de reprodução dos agentes do capital, que "não tem condições de transformar as relações sociais de dominação, podendo no máximo mediá-las" (PROGRAMA..., s/d apud GOULART, 2011a, p. 206).

"Sabemos que na atual forma de organização social não há espaço para a realização dos interesses da maioria, os trabalhadores. Tudo é transformado em mercadoria, inclusive nós próprios e nossos direitos. Apenas uma minoria tem acesso a condições dignas de vida. E o Estado atende exatamente a esta minoria." (MTST - CARTILHA DE PRINCÍPIOS, s/d, pg.03)

Neste sentido, a relação com o Estado nos processos de lutas sociais demanda uma atenção e um preparo constante por parte do movimento, que não deve pressupô-lo ao seu lado, como em certo sentido foi feito pelos movimentos sociais ligados à Reforma Urbana. Essa compreensão frente ao Estado, seguido pelo MTST, permite que ele esteja mais atento às limitações do Estado e às necessidades de recuos e ofensivas de sua parte nos processos de negociação e reivindicação. Reposiciona-se, assim, tanto o papel do Estado na sua análise quanto das demais forças do capital atuantes da cidade, como o mercado imobiliário, o mercado financeiro, os grandes proprietários de terras, etc. Inclusive estes aparecem na leitura de realidade do MTST de maneira mais recorrente e são interpretados como forças sociais relevantes no jogo político do urbano, que precisam ser combatidos, mas, para tanto, primeiro precisam ser compreendidos. Com isso, o movimento consegue fazer leituras de realidade mais pragmáticas em termos de reconhecimento das forças sociais com as quais travará disputas políticas.

Assim, o olhar menos romantizado ao Estado, por parte do MTST, e às suas prerrogativas potencializa uma compreensão da realidade e das novas regras do jogo em voga nas cidades e influencia, também, na forma que o movimento encara o campo jurídico-institucional como estratégia na realização da Reforma Urbana. 
"O centro das lutas não é o direito, o Estado, ou a cultura política, mas a existência da sociedade capitalista e da dominação de classe. A cidadania é um conceito, uma noção, um objetivo, que não aparece no horizonte estratégico do MTST, pois é superado pela concepção de que o direito é um atributo formal, embora importante e que exista apenas por conquista e não por concessão. Assim sendo, a noção de direito aparece nos discursos e nas ações como um instrumento para desvendar a desigualdade entranhada no Estado, que "dá para os ricos e tira dos pobres" e como argumento para a unidade e ação na luta, como o "direito a moradia" (GOULART, 2011a, p. 207)

As esferas institucionais são avaliadas pelo MTST como espaços em que as lutas sociais são amortecidas e restringidas, de maneira que não constam dentre as estratégias políticas do movimento. Aliado a isso, o direito também passa por um processo de ressignificação e acaba perdendo a centralidade estratégica que tinha anteriormente, para transformar-se em uma prática voltada prioritariamente à luta direta realizada pelo MTST por meio das ocupações. O direito assume, neste sentido, uma posição circunstancial nas lutas do MTST, sendo mobilizado e instrumentalizado na medida em que os processos políticos específicos de cada ocupação lhe demanda. A centralidade estratégica está nas lutas diretas direcionadas às ruas e realizadas por milhares de acampados organizados e politizados localmente nas ocupações.

Esta é, inclusive, uma marca do novo ciclo de lutas urbanas. Ao afastar-se dos espaços institucionais de participação e também das lutas jurídicas, o MTST faz das ruas seu espaço privilegiado de manifestação, ao mesmo tempo que as ocupações são seus espaços privilegiados de organização e politização da base que compõe os atos de rua. Há, neste sentido, uma retroalimentação das ocupações para as ruas, das ruas para as ocupações.

Com essa dinâmica entre rua e ocupação, o movimento consegue ter uma grande força mobilizatória e assim interferir tanto em processos políticos mais amplos quanto nas negociações relativas às lutas locais nas ocupações. 
A análise do direito como prática do MTST nas lutas recentes do novo ciclo não representa, entretanto, uma ruptura absoluta com as práticas dos movimentos ligados ao ciclo da Reforma Urbana. Apesar das manifestações das Jornadas de Junho demandarem tal ruptura, os processos políticos inaugurados também levam consigo marcas dos processos anteriores, em um movimento histórico dialético de avanços e retrocessos.

Neste sentido, parece que os sentidos dados às ocupações e especialmente ao direito pelo MTST guarda grande relação com os processos de lutas e avanços institucionais que os movimentos ligados à Reforma Urbana angariaram. Pois se, atualmente, não tivéssemos legislações que definissem termos como 'subutilizados', que indicassem os procedimentos de aplicação do Parcelamento, Uso e Edificação Compulsórios (PEUC), que restringissem o direito de propriedade ao cumprimento da sua função social, não seria possível ressignificar o direito como uma prática circunstancial às lutas das ocupações.

Neste contexto, o sentido das lutas pela Reforma Urbana parece ser ressignificado, para ser encarado a partir de uma leitura de realidade de esquerda, atualizada e que consegue localizar melhor as principais forças na produção da cidade e na qual as limitações e potencialidades do Estado são sempre avaliadas.

Claro que o novo ciclo de lutas urbanas impulsionado pelas Jornadas de Junho ainda está dando seus primeiros passos e que seria absolutamente precipitado afirmar qualquer assertividade dos seus rumos. O período que vivemos, especialmente desde 2013, é um período de grandes reviravoltas políticas e, neste sentido, traz uma complexidade e demanda um forte esforço daqueles que atuam politicamente nos processos de lutas. Mais do que saber se as ações estão certas ou erradas, se são inovadoras ou 'mais do mesmo', parece que o esforço está em evidenciá-las. Por isso, nesta dissertação, não nos propomos a fazer uma análise do ciclo em si, mas da utilização de estratégias e principalmente do direito pelo MTST durante esse ciclo, como um ponto de partida para iluminar o debate sobre o novo período de lutas urbanas. 


\section{considerações finais}

Nesta dissertação, nos propusemos a levantar apontamentos sobre os rumos das lutas pela Reforma Urbana por meio da análise dos usos e dos pesos dados ao direito. Ao longo do processo de pesquisa e de redação deste trabalho, a tarefa mostrou-se árdua, principalmente no que tange aos rumos mais recentes da luta pela Reforma Urbana, já que temos pouco distanciamento temporal para constituir uma análise apurada.

Ainda assim, o esforço despendido nesta análise nos parece fundamental. Isso porque a Reforma Urbana, enquanto uma bandeira de luta evocada nos processos sociais e políticos que têm a cidade como seu palco e sua pauta, demanda um projeto político robusto, formulado a partir de um esforço constante de avaliação e reinvenção. E apontarmos os rumos desse projeto, a partir da análise das estratégias priorizadas pelos movimentos protagonistas em cada momento da Reforma Urbana, pode ser uma contribuição modesta para o debate sobre as lutas urbanas e a organização das camadas populares.

Além disso, entendemos que a presente análise pode contribuir, no limite das suas possibilidades, para a indicação de novos caminhos da pesquisa do direito nos marcos do urbanismo.

Isso porque não raro o direito ainda é associado a uma ciência que o naturaliza como uma ordem normativa imposta pelo Estado e que, enquanto campo científico, tem um caráter de definitividade e fundamenta-se a partir das suas fontes tradicionais, como as leis, a jurisprudência, a doutrina e os costumes (PAZELLO, MASO, KOBORA, 2011). E, 
apesar do advento das teorias e métodos em antropologia do direito e em teoria do direito terem tido um papel fundamental no questionamento dessa visão cientificista e definitiva do direito, ainda é muito comum que se relacione a pesquisa em tal campo do conhecimento com uma pesquisa voltada às leis e à análise de jurisprudência e decisões judiciais sobre algum tema específico.

Esta mesma relação parece também ser reproduzida em certa medida no campo do direito que se relaciona diretamente com a questão urbana, a saber, o direito urbanístico. Não raro, suas análises são prioritariamente baseadas nos estudos das fontes tradicionais do direito já mencionadas, articulando-as de diferentes formas. Assim, é notável as análises se direcionarem à investigação sobre o sistema em si (seus princípios, evolução, autonomia, marcos fundamentais) ou sobre seus efeitos (aplicação ou inaplicabilidade, adequação ou inadequação).

Entretanto, é preciso reconhecer que o Direito é um fenômeno social complexo, uma construção histórica e cultural que, para ser apreendido, demanda não apenas a análise das suas regras já instituídas, mas também da relação que se estabelece entre direito e sociedade, entre direito e movimentos sociais, entre direito e lutas políticas. Neste sentido, tentamos, nesta dissertação, fazer um esforço de pesquisa a partir das práticas do direito para indicar como que ele também representa um campo no urbanismo para além das legislações urbanísticas e do debate sobre sua efetividade, tão comuns nas pesquisas.

A ideia foi privilegiar um olhar, a partir do direito, para os momentos da luta pela Reforma Urbana desenvolvidos nos últimos anos e, assim, levantar como o seu uso era mobilizado pelos movimentos sociais e o 'peso' a ele atribuído. Como indicamos nos capítulo 04 desta dissertação, o peso e o uso do direito nas lutas urbanas coincide com momentos ou ciclos de lutas, cuja conjuntura política é específica e única e nos quais diferentes movimentos, leituras de realidade e projetos políticos são protagonistas.

Neste sentido, o uso do direito e o peso a ele atribuído pelos movimentos sociais é aqui reiterado também como produto de uma conjuntura, para afastar um olhar que possa entendê-lo como uma mera escolha descolada dos processos políticos mais amplos. Se considerarmos esta chave, nos afastamos também de um olhar que quer estabelecer um mérito de adequação de cada ciclo ou mesmo de cada projeto político - ainda que, de 
fato, possamos avaliar seus erros e acertos, sem deixar de considerar, no entanto, a compreensão da sua origem e trajetória.

Conforme o caminho já delimitado no capítulo o1 desta dissertação, vimos como que na década de 80 , os usos do direito voltados à elaboração de direitos e à aprovação de leis urbanas ganharam força e se tornaram prioritários nas agendas de lutas dos movimentos sociais, notadamente do MNRU. Tais práticas eram reveladoras de uma leitura política que tinha a disputa no campo jurídico-institucional como estratégia e voltava suas ações para o Estado, no sentido de construir processos sociais como processos de construção e realização de cidadania.

Entretanto, a piora nas condições da vida urbana fez com que novos movimentos se articulassem em torno das questões urbanas e, assim, emergissem como novas forças sociais que, dentre suas bandeiras de luta, também evocavam a Reforma Urbana.

Assim, a partir do estudo dos usos do direito mobilizados pelo MTST, entendemos que parece ter havido uma ressignificação do seu peso como uma prática voltada à realização dos horizontes estratégicos do movimento - e não mais como estratégia em si - e reposicionamento de outras estratégias na centralidade de suas lutas, como é o caso das ocupações de terrenos urbanos.

Tal ressignificação e reposicionamento, como já ressaltamos, parece partir da história e do projeto político do MTST, cujas concepções classista e anticapitalista têm, de fato, contribuído para que ele desenvolva práticas e entendimentos que permitam um reposicionamento político da bandeira de luta pela Reforma Urbana. Esta, depois de anos privilegiando os espaços institucionais e as esferas dos poderes Executivo e Legislativo, parece ganhar um novo fôlego ao ser redirecionada para os debates políticos populares realizados nas ocupações e reivindicados nas ruas.

Assim, a partir dos espaços privilegiados de organização da sua base social - as ocupações -, o MTST constrói e dissemina um ideal de Reforma Urbana cujo horizonte político parece ser mesmo o da construção de uma cidade mais justa a partir não dos marcos do Estado - ou seja, da realização da cidadania, da elaboração de direitos, de decisões judiciais, de políticas públicas - mas a partir da reivindicação direta, perene e intensa da classe trabalhadora politizada. 


\section{bibliografia}

ARANTES, Pedro Fiori. Da (Anti)Reforma Urbana brasileira a um novo ciclo de lutas nas cidades. 2013. Disponível em:

$<$ http://www.correiocidadania.com.br/index.php?option=com content\&view=article\&id $=9047 \% 3 \mathrm{~A}>$. Acesso em 07/07/2017.

Para retomar o projeto da Reforma Urbana. Entrevista concedida à Patrícia Fachin do IHU Online, 2017. Disponível em:

$<$ http://outraspalavras.net/outrasmidias/destaque-outras-midias/para-retomar-o-projet o-da-reforma-urbana/>. Acesso em 21/05/2017.

BENOIT, H. O assentamento Anita Garibaldi: entrevista com lideranças do Movimento dos Trabalhadores Sem Teto (MTST). Revista Crítica Marxista, São Paulo, n.14, p. 134-149, 2002. Disponível em:

$<$ https://www.ifch.unicamp.br/criticamarxista/arquivos biblioteca/entrevista6134 merg ed.pdf>. Acesso em 21/05/2017.

BOITO JUNIOR, Armando. Estado, política e classes sociais: ensaios teóricos e históricos. São Paulo: Editora Unesp, 2007.

BONDUKI, Nabil; KOWARICK, Lúcio. Espaço urbano e espaço político: do populismo à redemocratização In: KOWARICK, Lúcio (org.). As lutas sociais e a cidade. São Paulo: Paz e Terra, 1994, cap. 05

BOULOS, Guilherme. Por que ocupamos? Uma introdução à luta dos sem-teto. 3. ed. São Paulo: Autonomia Literária, 2015a. 
De que lado você está? Reflexões sobre a conjuntura política e urbana no Brasil.

São Paulo: Boitempo Editorial. 2015b.

BRANDÃO, Lucas Coelho. Os movimentos sociais e a Assembleia Nacional Constituinte de 1987-1988: entre a política institucional e a participação popular. 2011. Dissertação (Mestrado em Sociologia) - Faculdade de Filosofia, Letras e Ciências Humanas da Universidade de São Paulo, São Paulo. Disponível em:

$<$ http://www.teses.usp.br/teses/disponiveis/8/8132/tde-16082012-125217/pt-br.php> Acesso em 26/08/2017.

CARDOSO, Adauto Lúcio. Reforma Urbana e Planos Diretores: avaliação da experiência recente. In: Cadernos do IPPUR, Rio de Janeiro, Ano XI, anos. 1 e 2, 1997. p.79-111.

CARTILHA do militante: movimento dos trabalhadores sem-teto. São Paulo, s/d.

DALLARI, Dalmo. A participação popular e suas conquistas in MICHILES, Carlos et al. Cidadão constituinte: a saga das emendas populares. Rio de Janeiro: Paz e Terra, 1989.

DAMATTA, Roberto. O Ofício do Etnólogo, ou como ter Anthropological Blues. In: NUNES, Edson de Oliveira. (org.). A Aventura Sociológica. Objetividade, Paixão, Improviso e Método na Pesquisa Social. Rio de Janeiro: Zahar, 1978, p. 23-35. Disponível em: $<$ https:/pt.scribd.com/document/51433408/DAMATTA-Roberto-O-oficio-de-etnologo-ou -como-ter-anthropological-blues > Acesso em 07/07/2017.

DAVIS, Mike. Planeta Favela. São Paulo: Boitempo Editoral, 2006.

DENALDI, R.; BRAJATO, D.; SOUZA, C. V.; FROTA, H. B. A aplicação do Parcelamento, Edificação ou Utilização Compulsórios. Urbe - Revista Brasileira de Gestão Urbana, 2017. Disponível em:

$<$ http:/www2.pucpr.br/reol/pb/index.php/urbe?ddI=16541\&dd99=view\&dd98=pb $>$. Acesso em 21/05/2017.

FERNANDES, Edésio; ALFONSIN, Betânia (coord). Coletânea de legislação urbanística: normas internacionais, constitucionais e legislação ordinária. Belo Horizonte: Fórum, 2010.

FERNANDES, Edésio. O Estatuto da Cidade e a ordem jurídico-urbanística. BRASIL. MINISTÉRIO DAS CIDADES. O Estatuto da Cidade Comentado. São Paulo: Ministério das Cidades: Aliança das Cidades, 2010. Disponível em:

$<$ http://www.cidades.gov.br/images/stories/ArquivosSNPU/Biblioteca/PlanelamentoUrb ano/EstatutoComentado Portugues.pdf>. Acesso em 07/07/2017. 
FIX, Mariana. Parceiros da exclusão: duas histórias da construção de uma 'nova cidade' em São Paulo: Faria Lima é Água Espraiada. São Paulo: Boitempo Editorial. 2001

São Paulo Cidade Global: fundamentos financeiros de uma miragem. São

Paulo: Boitempo Editorial. 2007

GOULART, Débora Cristina. O Anticapitalismo do Movimento dos Trabalhadores Sem-Teto (MTST). 2011a. Tese (Doutorado do Programa de Pós Graduação em Ciências Sociais) Faculdade de Filosofia e Ciências da Universidade Estadual Paulista, Campus Marília, São Paulo. Disponível em:

$<$ https://repositorio.unesp.br/bitstream/handle/11449/100930/goulart dc dr_mar.pdf?seq uence $=1>$. Acesso em 21/05/2017.

Do barracão à nacionalização: o Movimento dos Trabalhadores Sem Teto - MTST como proposta de poder popular e resistência ao neoliberalismo in ANAIS do I Simpósio Trabalhadores e a Produção Social. 2011b. Disponível em:

$<$ http://www.simposioproducaosocial.org.br/Trabalhos/401.pdf>. Acesso em 21/05/2017.

HARVEY, D. O trabalho, o capital e o conflito de classes em torno do ambiente contruído nas sociedades capitalistas avançadas. Revista Espaço e Debates, São Paulo, n. 6, jun/set 1982. p. 6-35.

IASI, Mauro. A rebelião, a cidade e a consciência. In HARVEY, David; MARICATO, Erminia; ŽIŽEK, Slavoj; DAVIS, Mike. et al. Cidades rebeldes: Passe Livre e as manifestações que tomaram as ruas do Brasil. São Paulo: Boitempo/Carta Maior, 2013 (e-book).

MARICATO, Erminia. Brasil, cidades: alternativas para a crise urbana. Petrópolis: Vozes, 2001.

. O impasse da política urbana no Brasil. 3 ed. Petrópolis, RJ: Vozes, 2014.

. Para entender a crise urbana. 1. ed. São Paulo: Expressão Popular, 2015.

A cidade é um grande negócio. Teoria e Debate, 03 Edição, o1 de julho de 1988. Disponível em:

$<$ http://teoriaedebate.org.br/index.php?q=materias/sociedade/cidade-e-um-grande-neg

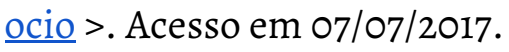

O Estatuto da Cidade Periférica. BRASIL. MINISTÉRIO DAS

CIDADES. O Estatuto da Cidade Comentado. São Paulo: Ministério das Cidades: Aliança das Cidades, 2010. Disponível em: 
$<\underline{\text { http://www.cidades.gov.br/images/stories/ArquivosSNPU/Biblioteca/PlanelamentoUrb }}$ ano/EstatutoComentado Portugues.pdf > Acesso em 07/07/2017.

. É a questão urbana, estúpido! In HARVEY, David; MARICATO, Erminia; ŽIŽEK, Slavoj; DAVIS, Mike. et al. Cidades rebeldes: Passe Livre e as manifestações que tomaram as ruas do Brasil. São Paulo: Boitempo/Carta Maior, 2013 (e-book).

MARTINS, Karoline Ferreira. O Direito que nasce da luta: a construção social do direito à moradia e à cidade pelo Movimento dos Trabalhadores Sem Teto no Distrito Federal. Dissertação (Mestrado do Programa de Pós-Graduação em Direito) - Faculdade de Direito, Universidade de Brasília. Brasília. 2015.

MARTINS, Maria Lucia Refinetti Rodrigues. O centro da metrópole e a metrópole como centro. Trabalho apresentado ao XII Encontro de Red Iberoamericana de Investigadores sobre Globalización y Territorio. Belo Horizonte, 2012, ppt.

MIAGUSKO, Edson. Movimentos de MOradia e Sem-Teto em São Paulo: experiências no contexto de desmanche. (Tese de Doutorado do Programa de Pós-Graduação em Sociologia) - Faculdade de Filosofia, Letras e Ciências Humanas, Universidade de São Paulo. São Paulo, 2008.

MICHILES, Carlos et al. Cidadão constituinte: a saga das emendas populares. Rio de Janeiro: Paz e Terra, 1989.

MOVIMENTO PASSE LIVRE. Não começou em Salvador, não vai terminar em São Paulo. In HARVEY, David; MARICATO, Erminia;ŽIŽEK, Slavoj; DAVIS, Mike. et al. Cidades rebeldes: Passe Livre e as manifestações que tomaram as ruas do Brasil. São Paulo: Boitempo/Carta Maior, 2013 (e-book).

NEPOMUCENO, Eric. O massacre: Eldorado do Carajás: uma história de impunidade. São Paulo: Editora Planeta do Brasil. 1997.

PAZELLO, Ricardo Prestes; MASO, Tchenna Fernandes; KOBORA, Igor Augusto Lopes. Entre antropologia e direito: perplexidades no ensino jurídico, Revista Direito e Práxis, Rio Grande do Sul, v. 3, p. 71-87, 2011.

PEREIRA, Rafael Borges. Contribuição ao debate sobre a Reforma Urbana: a questão da localização na cidade na luta dos movimentos de moradia. (Mestrado do Programa de PósGraduação em Arquitetura e Urbanismo) - Faculdade de Arquitetura e Urbanismo, Universidade de São Paulo. São Paulo, 2017. 
ROCHA, Antônio Sérgio. Genealogia do constituinte: do autoritarismo à democratização. In: Dossiê Constituição e Processo Constituinte. Lua Nova Revista de Cultura e Política. São Paulo: 2013, n. 88. Disponível em:

$<$ http:/www.scielo.br/scielo.php?script=sci arttext\&pid=S0102-64452013000100004.> Acesso em 07/07/2017.

ROLNIK, Raquel. A guerra dos lugares: colonização da terra e da moradia na era das finanças. São Paulo: Boitempo Editorial, 2015.

SADER, Eder. Quando novos personagens entraram em cena: experiências, falas e lutas dos trabalhadores da Grande São Paulo (1970-80). Rio de Janeiro: Paz e Terra, 1988.

SANTO AMORE, Caio. Entre o nó e o fato consumado, o lugar dos pobres na cidade: um estudo sobre as ZEIS e os impasses da reforma urbana na atualidade. 2013. Tese (Doutorado do Programa de Pós Graduação em Planejamento Urbano e Regional) - Faculdade de Arquitetura e Urbanismo da Universidade de São Paulo. Disponível em: $<$ http:/www.teses.usp.br/teses/disponiveis/16/16139/tde-05072013-102906/pt-br.php> Acesso em 21/07/2017.

SANTOS JUNIOR, Orlando Alves dos. O Fórum Nacional de Reforma Urbana: incidência e exigibilidade pelo direito à cidade. Rio de Janeiro: FASE, 2009. Disponível em:

$<$ http://polis.org.br/publicacoes/o-forum-nacional-de-reforma-urbana-incidencia-e-exig ibilidade-pelo-direito-a-cidade/>. Acesso em 21/07/2017.

Cidade, Cidadania e Planejamento Urbano: desafios na perspectiva da reforma urbana. In: FELDMAN, Sarah; FERNANDES, Ana. (Org.). O Urbano e o Regional no Brasil Contemporâneo: mutações, tensões, desafios. Salvador: EDUFBA, 2007, v. , p. 293-314. Disponível em:

$<$ http://labcs.ufsc.br/files/2011/12/02.-SANTOS-JUNIOR-O.-Cidade-cidadania-e-planeja mento-urbano.pdf>. Acesso em 07/07/2017.

SAULE JUNIOR, Nelson; SILVA, Ana Amélia da. A Cidade faz a sua Constituição. São Paulo: Pólis, 1993. Disponível em:

$<$ http://polis.org.br/publicacoes/a-cidade-faz-a-sua-constituicao/>. Acesso em 07/07/2017.

SAULE JUNIOR, Nelson; UZZO, Karina. A trajetória da reforma urbana no Brasil. Ciudadespara tod@s. Santiago-Chile: Habitat International Coalition, v. 1, p.259-270, 2010 
SANTOS, Boaventura de Sousa, O Estado, o Direito e a Questão Urbana. In: FALCÃO, Joaquim de Arruda (org.). Conflito de Direito de Propriedade: Invasões Urbanas. Rio de Janeiro: Comp. Editora Forense, 1984, p.1-78.

Notas sobre a história jurídico-social de Pasárgada. In SOUTO, Cláudio; FALCÃO, Joaquim (orgs). Sociologia Jurídica. São Paulo: Pioneira, 1980.

SESSÃO LIVRE 32. Ativismo Urbano: novas formas de conflitos territoriais. In: ANAIS XVII ENANPUR. 2017. Disponível em:

$<$ http://anpur.org.br/xviienanpur/principal/publicacoes/XVII.ENANPUR Anais/SL Sess oes Livres/SL\%2032.pdf >. Acesso em 21/05/2017.

SILVA, Ana Amélia. A Reforma Urbana e o Direito à Cidade. São Paulo: Instituto Pólis, 1991. Disponível em: $<$ http://polis.org.br/publicacoes/reforma-urbana-e-o-direito-a-cidade/>. Acesso em 07/07/2017.

SINGER, André. Os sentidos do lulismo: reforma gradual e pacto conservador. São Paulo, Companhia das Letras, 2012

STEDILE, João Pedro e FERNANDES, Bernardo Mançano. Brava gente: a trajetória do MST e a luta pela terra no Brasil. São Paulo: Fundação Perseu Abramo. 1999. Disponível em: $<$ https://goo.gl/YoKBNg > Acesso em 25/05/2017.

TANAKA, Giselle. Planejar para lutar e lutar para planejar: possibilidades e limites do Planejamento Alternativo. Tese (Doutorado no Instituto de Pesquisa e Planejamento Urbano e Regional) - Programa de Pós-Graduação em Planejamento Urbano e Regional, Universidade Federal do Rio de Janeiro. Rio de Janeiro, 2017.

TATAGIBA, Luciana; PATERNIANI, Stella Zagatto; TRINDADE, Thiago Aparecido. Ocupar, reivindicar, participar: sobre o repertório de ação do movimento de moradia de São Paulo. Opinião Pública, Campinas, v. 18, n. 02, 2012.

TELLES, Vera da Silva. Anos 1970: experiências, práticas e espaços políticos. In: KOWARICK, Lúcio (Org.). As Lutas Sociais e a Cidade. Rio de Janeiro: Paz e Terra, 1994, cap. 07

\section{Legislação}

BRASIL. Constituição (1988). Constituição da República Federativa do Brasil. Disponível em: <http:/www.planalto.gov.br/ccivil 03/constituicao/constituicao.htm> Acesso em 26/08/2017. 
BRASIL. Estatuto da Cidade - Lei Federal $n^{\circ} 10.257$, de 10 de julho de 2001 . Regulamenta os arts. 182 e 183 da Constituição Federal, estabelece diretrizes gerais da política urbana e dá outras providências. Disponível em:

$<$ http://www.planalto.gov.br/ccivil 03/leis/LEIS 2001/L10257.htm>Acesso em 05/05/2017.

BRASIL. Lei ${ }^{\circ}$ Federal 11.977, de 7 de julho de 2009. Dispõe sobre o Programa Minha Casa, Minha Vida - PMCMV e a regularização fundiária de assentamentos localizados em áreas urbanas; altera o Decreto-Lei $n^{0} 3.365$, de 21 de junho de 1941, as Leis $n^{\text {os }} 4.380$, de 21 de agosto de 1964, 6.015, de 31 de dezembro de 1973, 8.036, de 11 de maio de 1990, e 10.257, de 10 de julho de 2001, e a Medida Provisória n².197-43, de 24 de agosto de 2001; e dá outras providências. Disponível em:

<http://www.planalto.gov.br/ccivil 03/ ato2007-2010/2009/lei/l11977.htm> Acesso em 05/05/2017.

SÃO PAULO (MUNICÍPIO). Lei no 13.885, de 25 de agosto de 2004. Estabelece normas complementares ao Plano Diretor Estratégico, institui os Planos Regionais Estratégicos das Subprefeituras, dispõe sobre o parcelamento, disciplina e ordena o Uso e Ocupação do Solo do Município de São Paulo. Disponível em:

$<$ http://www.prefeitura.sp.gov.br/cidade/secretarias/urbanismo/legislacao/planos regio nais/index.php?p=822> Acesso em 26/08/2017.

\section{Portais eletrônicos}

Fundação Perseu Abramo <https://fpabramo.org.br/> Lado Esquerdo - Blog <http://ladoesquerdoo1.blogspot.com.br/> Ministério das Cidades <https://www.cidades.gov.br/> Movimento dos Trabalhadores Sem Teto (MTST) <www.mtst.org/> Senado Federal <www12.senado.leg.br/> Tribunal de Justiça do Estado de São Paulo <www.tjsp.jus.br>

\section{Notícias}

A NOVA ocupação gigante do MTST em São Paulo. Portal Outras Mídias, 14/04/2017. Disponível em:

$<$ http://outraspalavras.net/outrasmidias/destaque-outras-midias/a-nova-ocupacao-giga nte-do-mtst-em-sao-paulo/> Acesso em 05/05/2017.

ATO DA OCUPAÇÃO Povo Sem Medo Guarulhos pressiona Poder Público por moradia. Portal de notícias do MTST, 08/06/2017. Disponível em:

$<$ http:/www.mtst.org/mtst/ato-pela-ocupacao-povo-sem-medo-guarulhos-pressiona-po der-publico/> Acesso em 08/07/2017. 
CARTA DO MTST de saída da CSP-Conlutas. Portal do Partido Socialismo e Liberdade (PSOL), 14/07/2012. Disponível em:

<http://psol50sp.org.br/blog/2012/07/15/carta-do-mtst-de-saida-da-csp-conlutas/> Acesso em 26/08/2017.

COMO ORGANIZAR UMA OCUPAÇÃO. Documento interno do MTST, s/d.

CONQUISTAS avançam com a luta do MTST (SP). Blog Pela Moradia, 13/03/2014.

Disponível em:

$<$ https://pelamoradia.wordpress.com/2014/03/18/conquistas-avancam-com-a-luta-do-mt st-sp/>Acesso em 21/05/2017.

DEPUTADO Aleluia representa contra líder do MTST na Procuradoria da República.

Portal O democratas, 30/03/2016. Disponível em:

$<$ http:/www.dem.org.br/noticias/deputado-aleluia-representa-contra-lider-do-mtst-naprocuradoria-da-republica/> Acesso em 21/07/2017

DEZ DIAS APÓS ocupação, Copa do Povo reúne 7.000 pessoas: "nós vamos resistir até o fim". Portal de notícias R7, 14/05/2014. Disponível em:

$<$ http://noticias.r7.com/sao-paulo/fotos/dez-dias-apos-ocupacao-copa-do-povo-reune-7 ooo-pessoas-nos-vamos-resistir-ate-o-fim-14052014\#!/foto/9> Acesso em 05/05/2017.

DOCUMENTÁRIO 'OCUPADOS' - Ocupação Dona Deda. Portal Fala Universidades, 27/06/2016. Disponível

em: $<$ http://falauniversidades.com.br/ocupados-documentario-sobre-o-movimento-mtst -esta-disponivel-na-internet/> Acesso em 26/08/2017.

ESTAIADINHA arranca acordo de moradias em São Paulo (SP). Blog Pela Moradia, 04/12/2013. Disponível em:

$<$ https:/pelamoradia.wordpress.com/2013/12/04/estaiadinha-arranca-acordo-de-moradi as-em-sao-paulo-sp/> Acesso em 08/07/2017.

FALA ADVOGADO do MTST na primeira assembléia da Ocupação Esperança Vermelha. Página de rede social - Facebook do MTST, 20/03/2016. Disponível em: $<$ https://www.facebook.com/mtstbrasil/videos/1073072692731061/> Acesso em 08/07/2017.

HADDAD ALTERA decreto e libera 3.500 moradias populares em nova palestina. Portal de notícias Metrô News. 25/11/2014. Disponível em:

$<$ http://www.metronews.com.br/ultimas/haddad-altera-decreto-decreto-e-libera-3-500moradias-populares-em-nova-palestina/> Acesso em 21/05/2017. 
HADDAD DIZ AO MTST que muda destinação de terreno se plano diretor for aprovado. Portal Carta Capital, 27/03/2014. Disponível em:

$<$ https://www.cartacapital.com.br/politica/haddad-diz-ao-mtst-que-muda-destinacao-d e-terreno-se-plano-diretor-for-aprovado-6659.html> Acesso em 21/05/2017.

HADDAD DIZ que cede 'Nova Palestina' se plano diretor for aprovado. Portal de notícias G1, 26/03/2014. Disponível em:

$<$ http://g1.globo.com/sao-paulo/noticia/2014/03/haddad-diz-que-cede-nova-palestina-se -plano-diretor-aprovado.html> Acesso em 21/05/2017.

JUSTIÇA MANDA soltar militantes do MTST presos durante greve geral. Portal UOL Notícias, 04/05/2017. Disponível em:

$<$ https://noticias.uol.com.br/ultimas-noticias/agencia-brasil/2017/05/04/justica-manda-s oltar-militantes-do-mtst-presos-durante-greve-geral.htm > Acessado em 05/05/2017

MALABARISMO eleitoral. Folha de S.Paulo, 30/07/2014. Disponível em:

$<$ http:/www1.folha.uol.com.br/opiniao/2014/07/1493069-editorial-malabarismo-eleitoral .shtml> Acesso em 08/07/2017.

MANIFESTAÇÕES levam I milhão de pessoas às ruas em todo o país. Folha de S.Paulo, 20/06/2013. Disponível em:

$<$ http://www1.folha.uol.com.br/cotidiano/2013/06/1298755-manifestacoes-levam-1-milha o-de-pessoas-as-ruas-em-todo-pais.shtml>. Acesso em 08/07/2017.

MANIFESTO DE APOIO à luta por moradia em São Paulo e à Ocupação Vila Nova Palestina (SP). Blog Pela Moradia, 11/12/2013. Disponível em:

$<$ https://pelamoradia.wordpress.com/2013/12/11/manifesto-de-apoio-a-luta-por-moradia -em-sao-paulo-e-a-ocupacao-vila-nova-palestina-sp/> Acesso em 08/07/2017.

MORADIA LEVA mais às ruas do que a copa. O Estado de São Paulo, 07/05/2014. Disponível em:

$<$ http://sao-paulo.estadao.com.br/noticias/geral,moradia-leva-mais-as-ruas-do-que-cop a,1163111>. Acesso em 07/07/2017.

MTST ANUNCIA FIM da ocupação na zona leste de SP. Portal de notícias Estado de Minas (EM), 29/08/2014. Disponível em:

$<$ http://www.em.com.br/app/noticia/nacional/2014/08/29/interna nacional,563791/mtstanuncia-fim-da-ocupacao-na-zona-leste-de-sp.shtml> Acesso em 05/05/2017.

MTST - CARTILHA DE PRINCÍPIOS, s/d. Disponível em:

$<$ http://www.mtst.org/linhaspoliticaseorganizativas.pdf $>$ Acesso em 07/07/2017. 
MTST INVADE NOVO TERRENO em São Paulo e impede cadastramento em ocupação. Portal Revista Veja, 21/06/2014. Disponível em:

$<$ http://veja.abril.com.br/politica/mtst-invade-novo-terreno-em-sao-paulo-e-impede-ca dastramento-em-ocupacao/> Acesso em 05/05/2017.

MTST OCUPA SEDE de incorporadora dona da área da ocupação 'Copa do Povo'. Portal Rede Brasil Atual, 20/05/2014. Disponível em:

$<$ http://www.redebrasilatual.com.br/cidadania/2014/05/mtst-ocupa-sede-de-incorporad ora-dona-da-area-da-ocupacao-copa-do-povo-3140.html> Acesso em 05/05/2017.

MTST PROMETE DEIXAR Copa do Povo e dona da área concorda com venda. Portal de notícias $\mathrm{G1}$, 03/07/2014. Disponível em:

$<$ http://g1.globo.com/sao-paulo/noticia/2014/o7/mtst-promete-deixar-copa-do-povo-e-d ona-da-area-concorda-com-venda.html> Acesso em 05/05/2017.

MTST PROMETE DEIXAR Copa do Povo e dona da área concorda com venda (vídeo). Portal Globo Play, 04/07/2014. Disponível em:<https://globoplay.globo.com/v/3474706/> Acesso em Acesso em 05/05/2017.

MTST: 17 ANOS organizando a luta pela moradia. Portal Liberdade-Socialismo-Revolução (LSR), 13/08/2014. Disponível em:

<https://www.lsr-cit.org/2014/08/13/mtst-17-anos-organizando-a-luta-pela-moradia/> Acesso em 05/05/2017.

MTST: MILHARES na Prefeitura de São Paulo (SP). Blog Pela Moradia, 20/03/2014. Disponível em:

$<$ https://pelamoradia.wordpress.com/2014/03/20/mtst-milhares-na-prefeitura-de-sao-p aulo-sp/> Acesso em 05/05/2017.

NÃO É POSSÍVEL reforma urbana popular sem enfrentamento com o capital - entrevista com Guilherme Boulos, coordenador nacional do MTST. Portal Jornalismo B, 27/05/2015. Disponível em:

$<$ http://jornalismob.com/2015/05/27/nao-e-possivel-reforma-urbana-popular-sem-enfre ntamento-com-o-capital-entrevista-com-guilherme-boulos-coordenador-nacional-do-m tst/> Acesso em 05/05/2017.

OCUPAÇÃO CARLOS MARIGHELLA: a luta pela moradia. Carta Maior, 16/12/2014. Disponível em:

$<$ http://www.cartamaior.com.br/?/Editoria/Movimentos-Sociais/Ocupacao-Carlos-Mari ghella-a-luta-pela-moradia/2/32446> Acesso em 05/05/2017. 
OCUPAÇÃO DONA DEDA completa um mês no Campo Limpo. Portal de notícias Momento Online FIAMFAAM, 05/12/2013. Disponível em:

$<$ http:/www.fiamfaam.br/momento/?pg=leitura\&id=5100\&cat=0 $>$ Acesso em 05/05/2017.

OCUPAÇÃO FAIXA DE GAZA resiste em São Paulo (SP). Blog Pela Moradia, 02/09/2013. Disponível em:

$<$ https://pelamoradia.wordpress.com/2013/09/02/ocupacao-faixa-de-gaza-resiste-em-sa o-paulo-sp/> Acesso em 08/07/2017.

OCUPAÇÃO NOVA PALESTINA, em São Paulo, quadruplica em um mês. Portal Valor Econômico, 10/01/2014. Disponível em:

$<$ http:/www.valor.com.br/politica/3391140/ocupacao-nova-palestina-em-sao-paulo-quad ruplica-em-um-mes> Acesso em 08/07/2017.

OCUPAÇÃO PERTO DO ITAQUERÃO é batizada de 'Copa do Povo', Portal de notícias Terra, 05/05/2014. Disponível em:

$<$ https://www.terra.com.br/noticias/brasil/cidades/sp-ocupacao-perto-do-itaquerao-e-b atizada-de-copa-do-povo,1c7fd3e794dc5410VgnVCM5000009ccceboaRCRD.html> Acesso em 07/05/2017.

OCUPAÇÃO POVO SEM MEDO Guarulhos, no Pimentas, chega a 6,7 mil famílias. Portal de notícias do MTST, 30/06/2017. Disponível em:

$<$ http://www.mtst.org/mtst/ocupacao-povo-sem-medo-guarulhos-no-pimentas-chega-a -67-mil-familias/> Acesso em 08/07/2017.

PM FAZ REINTEGRAÇÃO em área ocupada pelo MTST no Morumbi. Portal de notícias Terra, 28/07/2014. Disponível em:

<https:/www.terra.com.br/noticias/brasil/cidades/sp-pm-faz-reintegracao-em-area-ocu pada-pelo-mtst-no-morumbi,5c29762fb7c77410VgnVCM4000009bcceboaRCRD.html> Acesso em 07/05/2017.

PRESOS POLÍTICOS do MTST estão livres. Portal do MTST, 05/05/2017. Disponível em: $<$ http:/www.mtst.org/mtst/presos-politicos-do-mtst-estao-livres/> Acessado em 26/08/2017.

PROMOTORIA aponta dúvida sobre total de ocupantes na Copa do Povo. Portal de notícias G1, 21/06/2014. Disponível em:

<http:/g1.globo.com/sao-paulo/noticia/2014/06/promotoria-aponta-duvida-sobre-totalde-ocupantes-na-copa-do-povo.html> Acessado em 05/05/2017.

SEM-TETO FECHAM a Radial Leste e protestam em frente ao Itaquerão. Portal de notícias último segundo ig, 15/05/2014. Disponível em: 
$<$ http://ultimosegundo.ig.com.br/brasil/sp/2014-05-15/sem-teto-fecham-a-radial-leste-eseguem-em-direcao-ao-itaquerao.html> Acesso em 05/05/2017.

SEM-TETO INVADEM SABESP para cobrar rede de água e esgoto na ocupação Copa do Povo. O Estado de São Paulo, 12/05/2016. Disponível em:

$<$ http://sao-paulo.estadao.com.br/noticias/geral,sem-teto-invadem-sabesp-para-cobrarrede-de-agua-e-esgoto-na-copa-do-povo,1867989> Acesso em 05/05/2017. 